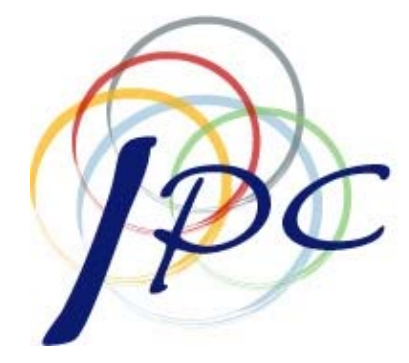

InTERnational Policy Center

Gerald R. Ford School of Public Policy University of Michigan

IPC Working Paper Series Number 9

Are Financial Crises Indeed "Crises?" Evidence from the Emerging ADR Market

\author{
Paolo Pasquariello
}

Revised November 2005 


\title{
Are Financial Crises Indeed "Crises?" Evidence from the Emerging ADR Market
}

\author{
Paolo Pasquariello ${ }^{1}$ \\ Ross School of Business at University of Michigan
}

1 Please address comments to the author at the Ross School of Business at University of Michigan, Department of Finance, 701 Tappan Street, Suite 5210, Ann Arbor, MI 48109-1234, or via email at ppasquar@bus.umich.edu. I benefited from the comments of Warren Bailey, Geert Bekaert, Sreedhar Bharath, Vihang Errunza, Daniel Isidori, Andrew Karolyi, Esa Jokivuolle, Roberto Rigobon, Ivo Welch, and participants in seminars at the University of Michigan, the 2004 EFA Meetings, and the 2005 AFA Meetings. Any remaining errors are my own. 


\begin{abstract}
The recent episodes of financial turmoil in Mexico, East Asia, Russia, Brazil, and Argentina are often dubbed financial crises. However, the severe downturns in equity markets, abrupt currency devaluations, and massive capital flight that characterize these events can still be deemed compatible with efficient and well-functioning financial markets. Thus, why is a financial crisis a "crisis?" To answer this question, we conduct an empirical investigation of the efficiency and pricing of the emerging ADR market. More specifically, using a non-parametric technique, we test for regime shifts in two basic structural relationships for ADR returns in 20 emerging countries, identified via arbitrage and capital mobility considerations, that should always hold in efficient and integrated capital markets. We find that those "normal" market conditions were instead violated in proximity of financial crises: The law of one price often weakened (by $54 \%$ on average), and domestic sources of risk became more important (often by more than 100\%) for many depositary receipts in our sample. We also find that some popular explanations for the occurrence of financial crises in emerging economies, in particular uncertainty among investors, exchange rate volatility, economic integration, and liquidity (but not contagion, financial integration, currency devaluations, capital flight, capital controls, or the legal environment for stock trading and holding) made their equity markets less efficient as well. Based on this evidence, we can state with greater confidence that those episodes of financial turmoil were indeed "crises."
\end{abstract}

JEL classification: F37; G15

Keywords: Regime Shifts; Financial Crises; ADRs; Market Efficiency 


\section{Introduction}

What is a financial crisis? The prevalent answer to this question, in academia as well as in the financial press, is that financial crises are episodes of turmoil in domestic and global financial markets. Such turmoil is generally characterized by sudden, severe, often deemed "excessive," downward price movements, scarce or drying liquidity, rapid reversals of capital flows, and contagious propagation of shocks across stock, currency, and sovereign debt markets. ${ }^{1}$ As a consequence, the events that took place in Mexico at the end of 1994, in East Asia between 1997 and 1998, in Russia during the summer of 1998, in Brazil in 1999, and in Argentina in 2002 are usually dubbed "financial crises."

Another question does, however, arise from this broad definition: Why is a financial crisis a "crisis?" After all, large declines in returns and portfolio shifts, significant capital flights, and the reduced willingness of speculators to take positions in certain assets, although socially costly, may result from rational, rapid revisions of investors' beliefs about the fundamentals of the traded securities. The word "crisis" is instead suggestive of market breakdowns or failures, seemingly unreasonable behavior of investors and speculators, or inefficient allocation of resources and risks, hence, in short, of the occurrence of unusual, possibly irrational phenomena. Accordingly, identifying the nature of the aforementioned events should accompany policy-makers and regulators' efforts at formulating prescriptions to prevent their occurrence and/or attenuate the severity of their effects. For example, should new rules be enacted to improve the efficiency and integration of the world financial markets, or should their natural exuberance simply be restrained during periods of instability, as in the case of Malaysia in $1998 ?$

The objective of this paper is to address the identification issue directly. More specifically, we intend to assess the efficiency of emerging capital markets in proximity of recent episodes of international financial instability. To that purpose, we specify two basic arbitrage and pricing relationships which, even after allowing for frictions and transaction costs, should always hold in these markets, when efficient. Then, we test whether they fail to do so during those times of "crisis." We focus on the market for emerging American Depositary Receipts (ADRs). ADRs are dollar-denominated rights, priced in the U.S. stock market, to shares of foreign companies traded in their domestic exchanges. According to Bailey et al. (2000), ADRs account for much trading in emerging market equities. Depositary receipts allow in fact investors to trade in more transparent and liquid markets (the NYSE, NASDAQ, or AMEX) than those of the issuers.

More importantly, the ADR market represents an ideal environment to determine whether

\footnotetext{
${ }^{1}$ See Kallberg et al. (2005) for a review of the literature on financial crises.
} 
the efficiency of the emerging equity markets deteriorates during periods of financial stress. In each of those markets, in fact, ADRs and their corresponding amounts of shares of the domestic issuers should always be perfect substitutes. Most of the available research on the subject (see Section 2) argues that this is generally the case, in the absence of investment restrictions, when taxes, transaction costs, liquidity, and nonsynchronicity issues are considered. This implies that the relationship between the dollar return for a depositary receipt and the dollar return for the underlying security should always satisfy the law of one price, even after accounting for those financial frictions, unless "normal" market conditions are violated.

Further, in perfectly open, fully integrated financial markets, ADR prices should be related exclusively to their covariance with world factors. Most emerging economies have experienced some form of capital market liberalization in the last decade. As a result of this process, foreign investors can now trade in domestic assets and domestic investors in foreign assets. However, since investors' portfolios still display significant home bias (e.g., Tesar and Werner, 1995a), local sources of risk could affect ADR prices as well. These factors may become even more relevant during episodes of financial turmoil. Many of these events have been associated with the occurrence of purely idiosyncratic shocks, like political instability, fiscal crises, monetary indiscipline. In addition, in several of those circumstances (most notably in the case of Malaysia in the late 1990s), local authorities reacted to generalized sales of domestic assets by erecting new barriers to capital flows (e.g., pegging unilaterally their currencies and limiting the activities of foreign speculators), hence segmenting back their financial markets. ${ }^{2}$ The dollar return for a depositary receipt should then become more sensitive to the dollar return for the local index where the underlying security is traded and less sensitive to the dollar return for an index of its own trading venue if, in proximity of periods of stress, "normal" pre-existing market conditions are violated.

Testing for and explaining regime shifts in the efficiency and pricing of emerging ADR markets is therefore the subject of this work. We start by translating the arbitrage and market integration arguments made above into two linear relationships between returns for each ADR in the sample, its corresponding local stock, and domestic and global sources of risk. Our basic dataset comprises weekly U.S. dollar returns for ADRs from issuers in 20 emerging markets: Argentina, Brazil, Chile, China, Colombia, Hong Kong, Hungary, India, Indonesia, Israel, Mexico, Peru, Philippines, Poland, Russia, South Africa, South Korea, Taiwan, Turkey, and Venezuela. ${ }^{3}$

\footnotetext{
${ }^{2}$ In 1997, Dr. Mahatir Mohamed, then the Prime Minister of Malaysia, called foreign hedge funds the "highwaymen" of the world financial markets (Chancellor, 2000). For more on the role of capital flight in the Asian crisis, see Kallberg et al. (2002).

${ }^{3}$ The choice of lower frequency data alleviates the potential impact of infrequent and nonsynchronous trading,
} 
Next, we search for breaks in these relationships using the non-parametric statistical methodology developed by Bai et al. (1998). This approach allows statistical inference on the nature of those breaks (and the estimation of confidence intervals around the estimated break dates) with minimal restrictions on the behavior of the involved variables. Moreover, these endogenous dates are unaffected by any prior bias about when the break is expected to happen.

We find that the law of one price did indeed cease to hold for many emerging depositary receipts in our sample in proximity of financial crises. Most of the estimated breaks in their basic no-arbitrage relationships cluster in 1994, between 1997 and 1998, and by the end of 2001. In those circumstances, the correlation between ADR returns and the dollar returns of their perfect substitutes weakened considerably (by $54 \%$ on average), especially in Chile, Mexico, Russia, and Venezuela. These shifts were often accompanied by greater dependency of ADR prices on domestic equity index returns (usually by more than 100\%), and were generally unrelated to the introduction of capital controls or endogenous dates of financial integration. Based on this evidence, we conclude that, during the various episodes of financial turmoil that took place over the last decade, the market for emerging ADRs was, on average, less efficient, more segmented, and relatively more sensitive to domestic sources of risk than during more tranquil times. As interestingly, however, those episodes of financial turmoil were not accompanied by any discernible market failure in the ADR pricing of at least half of the companies in our database, most notably in Brazil, China, and India.

Our analysis goes a step further. We intend in fact to explain the occurrence, dynamics, and clustering of these regime shifts, as well as the heterogeneous response of each country's ADRs to their happening. To accomplish this task, we consider a number of popular arguments in the literature (described in Section 6) to explain timing and evolution of financial crises. We devise various proxies for them, which can be grouped into seven main categories: Information, trend, economic environment, financial integration, investors' activity, market liquidity, and expected returns. We then include these variables in a Poisson model for the concentration of estimated breaks in each country in the sample. Its estimation indicates that greater confusion among foreign investors and exchange rate volatility, declining expected returns and liquidity, and shrinking trade (but not abrupt currency devaluations or foreign capital flight) make emerging ADR markets more likely to become less efficient and integrated. Finally, we find little or no evidence that financial contagion (measured with a novel methodology) and the legal environment for equity trading and holding (i.e., capital controls and investor protection) cause those nonoverlapping trading hours, and various microstructure frictions on the statistical analysis (e.g., Harvey, 1995; Bacidore and Sofianos, 2002). 
efficiency and pricing breaks and their propagation across markets and over time.

This work is closely related to two recent studies. Using intraday data, Gagnon and Karolyi (2004) detected significant, albeit rarely persistent, short-term ADR price parity violations, the greater so in the presence of "excess" systematic comovement with U.S. market returns. While their analysis is static in nature, the focus of our research is on the long-term dynamics of ADR pricing, and on its interaction with financial crises. Kallberg et al. (2005) found statistically significant breaks in linear relationships between the equity and currency markets of several East Asian countries during 1997 and 1998, and linked those episodes to herding by foreign investors. These structural dependencies, however, do not naturally arise from normal market conditions and are not bound to hold dynamically, regardless of whether those markets were experiencing a "crisis." The effort to identify and explain financial crises from specific market failures represents our original contribution to the literature on these fascinating, yet still obscure phenomena.

The paper is organized as follows. Section 2 identifies the basic efficiency and pricing relationships between ADR returns and their substitutes, as well as local and global sources of risk. Section 3 details the econometric approach to testing for breaks in these relationships. Section 4 describes the dataset employed in the analysis. We present and discuss the evidence on the occurrence and clustering of those regime shifts in Section 5. Section 6 investigates the significance of several alternative explanations for their time-series and cross-country dynamics. Section 7 concludes.

\section{Efficiency and pricing for ADR returns}

American Depositary Receipts (ADRs) are dollar-denominated, negotiable certificates representing a pre-specified amount of a foreign company's publicly traded equity, held on deposit in the issuer's domestic market. The depositary banks pass all dividends and payments related to the underlying shares, converted into U.S. dollars, to the holders of the ADRs, which therefore bear all currency risk and pay handling fees to the custodians. ADRs allow investors to achieve international diversification while avoiding hefty local fees (up to 40 basis points, according to Velli, 1994) and trade failures, common especially in emerging markets. ${ }^{4}$ There is a voluminous literature on international cross-listings, the efficiency of the ADR market, and the pricing of depositary receipts. Karolyi $(1998,2004)$ and Gagnon and Karolyi (2004) provide an exten-

\footnotetext{
${ }^{4}$ Further details concerning the types of ADR programs in the U.S. and the functioning of the ADR market are available in Kato et al. (1991) and Ely and Salehizadeh (2001), among others, and on the website of the Bank of New York (BoNY): http://www.adrbny.com/dr_edu_landing.jsp. BoNY is the world's largest depositary for ADRs.
} 
sive survey of this branch of international finance. Available research on the topic concentrated mainly on the impact of cross-listings on market price behavior, the risk and cost of capital of the issuers, the liquidity of their stocks, and the diversification opportunities for investors.

The holder of an ADR can redeem his certificate into the underlying shares at any point in time by simply paying a small service charge to the custodian. Conversely, new ADRs can be created at any point in time by simply depositing the appropriate number of those shares in the custodian's hands. Hence, in the absence of significant investment barriers and accounting for fluctuations in the exchange rate, ADRs and the underlying equity should be perfect substitutes. If $r_{i t}^{m}$ is the dollar return for the shares of company $i$ in country $m$ at time $t$ and $r_{i t}^{U S}$ is the dollar return for the corresponding depositary receipt at time $t$, the null hypothesis of perfect substitutability between the two securities implies that, in the relationship

$$
r_{i t}^{U S}=a_{i}+b_{i} r_{i t}^{m}+\eta_{i t}^{U S}
$$

both $a_{i}=0$ and $b_{i}=1 .^{5}$ By construction, the validity of these return restrictions is clearly independent of firm-specific events such as stock splits, dividend payments, capital structure decisions, or control changes. However, differential taxation rules (e.g., on the treatment of dividends), restrictions to capital mobility and foreign ownership of domestic stocks, involuntary dilution of ADR-holders' claims (due to S.E.C. rules on the exercise of rights), limited liquidity, and nonsynchronous trading may limit the efficient realignment of the dollar prices of ADRs and corresponding domestic stocks only within no-arbitrage bands such that $a_{i} \neq 0$ and/or $b_{i} \neq 1$. Most available studies (e.g., Rosenthal, 1983; Kato et al., 1992; Webb et al., 1995) conclude that the ADR market is at least weak-form efficient and that, after accounting for many of those frictions, the law of one price does indeed hold. One of the main objectives of this work is to test whether efficiency in the market for emerging ADRs is altered during periods of financial stress.

\footnotetext{
${ }^{5}$ This hypothesis is equivalent to requiring that, in the absence of capital and currency controls, as well as of transaction costs and time delays in ADR conversion, the law of one price holds for the prices of ADRs and their underlying local shares. Indeed, if $P_{i t}^{m}$ is the stock price of firm $i$ in country $m, P_{i t}^{U S}$ is the price of the corresponding $\mathrm{ADR}, \phi_{i}^{m}$ is the conversion ratio between the two (number of local shares underlying one ADR), and $S_{t}^{m}$ is the spot exchange rate (units of local currency per U.S. dollar), the law of one price requires that, from the perspective of a U.S. dollar-based investor, $P_{i t}^{U S}=\phi_{i}^{m} P_{i t}^{m} / S_{t}^{m}$ at each point in time $t$. Taking first differences leads to $P_{i t}^{U S}-P_{i t-1}^{U S}=\phi_{i}^{m}\left(P_{i t}^{m} / S_{t}^{m}-P_{i t-1}^{m} / S_{t-1}^{m}\right)$. Following standard practice in the literature testing for violations of the law of one price (e.g., Auguste et al., 2003), we derive Eq. (1) by taking first differences of $\log$ prices from the no-arbitrage condition above: $\ln P_{i t}^{U S}=\ln \phi_{i}^{m}+\left(\ln P_{i t}^{m}-\ln S_{t}^{m}\right)$ implying that $\ln P_{i t}^{U S}-\ln P_{i t-1}^{U S}=\left(\ln P_{i t}^{m}-\ln P_{i t-1}^{m}\right)-\left(\ln S_{t}^{m}-\ln S_{t-1}^{m}\right)$. This representation effectively reduces heteroskedasticity and dampens exponential growth patters common to some stocks in our sample. Results are qualitatively similar when using arithmetic price differences and are available upon request.
} 
Thus, we test whether the relations of Eq. (1) experience a regime shift in proximity of recent financial crises. ${ }^{6}$

Established theoretical research and much available empirical evidence support the case for international diversification. ${ }^{7}$ Hence, if the international capital markets were fully integrated and perfect capital mobility held, returns on ADRs should depend only on their covariances with one or many global market factors. Instead, the existence of home bias among domestic investors leads local market dynamics to affect ADR prices as well. ${ }^{8}$ The relevance of local factors may be even greater during periods of financial stress. Many of the recent episodes of financial turmoil raging through Asia and Latin America were in fact ignited or fueled by domestic events (e.g., political uncertainty, bank failures, explosive budget deficits, government defaults on bond payments).

In this paper we also test whether local market returns became more important in pricing emerging ADRs around the time of financial crises. To that purpose, we employ a standard multi-factor model in which factors typically proxy for sources of domestic and global market risk. The model can be written as

$$
r_{i t}^{U S}-r_{R F t}^{U S}=b_{i}^{m}\left(r_{M t}^{m}-r_{R F t}^{U S}\right)+b_{i}^{U S}\left(r_{M t}^{U S}-r_{R F t}^{U S}\right)+e_{i t}^{U S},
$$

where $r_{R F t}^{U S}$ is the U.S. risk-free rate of return at time $t, r_{M t}^{m}$ is the dollar return on the local market portfolio of the ADR's underlying stock at time $t$, and $r_{M t}^{U S}$ is the return on the U.S. market portfolio at time $t$. Similar specifications have been employed in several studies of crossborder listings (e.g., Jorion and Schwartz, 1986; Howe and Kelm, 1987; Karolyi, 1998; Foerster and Karolyi, 1999; Auguste et al., 2003). As argued in Section 1, a significant estimate for the local market coefficient $b_{i}^{m}$ in Eq. (2) provides evidence of capital market segmentation. Thus, this relation allows us to test for changes in the degree of market integration and capital mobility

\footnotetext{
${ }^{6}$ These tests are run from the perspective of a dollar-based investor, since both ADR and associated local stock returns are in dollar terms. As shown in Footnote 5, fluctuations in both the local share prices and the local exchange rate versus the dollar affect the extent to which the law of one price holds. Yet, no clear predictions for their relative importance, nor any general assumption about their interaction can be formulated. Nonetheless, the results that follow are qualitatively similar when we run tests from the perspective of local investors (i.e., using local currency returns). We explore in greater detail the role of exchange rate dynamics for the estimated regime shifts in Eq. (1) in Section 6.

${ }^{7}$ See the seminal contribution by Solnik (1974) and, more recently, Roll (1992), Ibbotson and Brinson (1993), Heston and Rouwenhorst (1994), and Griffin and Karolyi (1998), among others.

${ }^{8}$ For more on this topic, see Rowland (1999) and Karolyi and Stulz (2002). Earlier studies by Errunza and Losq (1985) and Alexander et al. (1987) find that global market returns still explain a greater portion of returns of portfolios of ADRs.
} 
in the context of the emerging $\mathrm{ADR}$ market, i.e., on whether $b_{i}^{U S}$ and/or $b_{i}^{m}$ experience a regime shift, in proximity of major financial crises. ${ }^{9}$

\section{Testing for regime shifts}

In this section we describe the methodology we use to test for breaks in the parameters of Eqs. (1) and (2). We choose to adopt the statistical methodology of Bai et al. (1998), since it allows statistical inference about structural breaks (including the estimation of confidence interval around the break dates) with minimal restrictions on the underlying data generation process. More specifically, Bai et al. (1998)'s non-parametric technique searches for a single break in univariate or multivariate time-series models (with or without stationary regressors) and generates asymptotic confidence intervals around their estimated break dates.

We start by generalizing the efficiency and pricing models of Eqs. (1) and (2) to allow for the possibility of a structural regime shift. If $k$ is a potential break date, $X_{i t}^{m}$ is a $1 \times N$ vector of country- or stock-specific regressors, and $\beta_{i}^{m}$ and $\Delta \beta_{i}^{m}$ are $N \times 1$ vectors of factor loadings, we specify the relation

$$
y_{i t}^{m}=X_{i t}^{m \prime} \beta_{i}^{m}+d_{t}(k) X_{i t}^{m \prime} S^{\prime} S \Delta \beta_{i}^{m}+\varepsilon_{i t}^{m}
$$

where $y_{i t}^{m}=r_{i t}^{U S}$ or $r_{i t}^{U S}-r_{R F t}^{U S}, d_{t}(k)=1$ if $t \geq k$ and zero otherwise, and $S$ is a binary selection matrix with unit diagonal elements corresponding to the coefficients in $\beta_{i}^{m}$ which are allowed to change. Hence, Eq. (3) is a model of full structural change if $S$ is equal to the $N \times N$ identity matrix $I_{N}$. The vector $S \Delta \beta_{i}^{m}$ can be interpreted as the change in the corresponding subset of coefficients after a break occurred. In more compact form, the above equation is equivalent to

$$
y_{i t}^{m}=Z_{i t}^{m}(k)^{\prime} B_{i}^{m}(k)+\varepsilon_{i t}^{m},
$$

where $Z_{i t}^{m}(k)^{\prime}=\left(X_{i t}^{m \prime}, d_{t}(k) X_{i t}^{m \prime} S^{\prime}\right)$ and $B_{i}^{m}(k)=\left(\beta_{i}^{m}, S \Delta \beta_{i}^{m}\right)$.

We are interested in testing the null hypothesis that $S \Delta \beta_{i}^{m}=0$, for $k=t^{*}+1, \ldots, T-t^{*}$, where $t^{*}$ is some trimming value. ${ }^{10}$ Bai et al. (1998)'s test for structural breaks to Eq. (3), based

\footnotetext{
${ }^{9}$ When studying a sample of ADR issuers from 11 countries in Europe, Canada, Asia, and Australia, Foerster and Karolyi (1999) find that, within one year from their listing decisions, their local stock returns' exposure to local market risk declined, while their exposure to global market risk was unaffected, i.e., that issuing ADRs led to greater market integration. Our analysis focuses instead on the dynamics of market betas of ADR returns not only immediately following the actual listing but also in proximity of periods of financial turmoil.

${ }^{10}$ Trimming is necessary for the model of Eq. (3) to be of full rank before and after any potential break date $k$.
} 
on Wald statistics and similar to that of Quandt $(1958,1960)$, considers the maximum of the following $F$ process:

$$
F_{i}^{m}(k)=T\left[R \widehat{B}_{i}^{m}(k)\right]^{\prime}\left\{R\left[T^{-1} \sum_{t=1}^{T} Z_{i t}^{m}(k) \widehat{\sigma}_{i m}^{2} Z_{i t}^{m}(k)^{\prime}\right]^{-1} R^{\prime}\right\}^{-1}\left[R \widehat{B}_{i}^{m}(k)\right],
$$

where $R=[0, S]$ is such that $R B_{i}^{m}(k)=S \Delta \beta_{i}^{m}$, and $\widehat{B}_{i}^{m}(k)$ and $\widehat{\sigma}_{i m}^{2}$ are OLS estimators for $B_{i}^{m}(k)$ and $\operatorname{var}\left(\varepsilon_{i}^{m}\right)$, respectively, under the alternative hypothesis of one break at date $k$. The

estimated break date is then $\widehat{k}_{i}^{m}=\arg \max F_{i}^{m}(k)$, and is statistically significant if $F_{i}^{m}\left(\widehat{k}_{i}^{m}\right)$ is greater than its critical value at the chosen level of significance. ${ }^{11}$

If a statistically significant break is detected in Eq. (4), the problem of constructing a confidence interval around $\widehat{k}_{i}^{m}$ is not trivial. Many authors have addressed this issue by assuming that residuals in Eq. (3) are normally distributed. ${ }^{12}$ Bai et al. (1998) instead only require that these disturbances form a sequence of martingale differences with some moment conditions. This restriction is in fact sufficient to specify the following asymptotic $100(1-\pi) \%$ confidence interval for the true break date:

$$
\widehat{k}_{i}^{m} \pm c_{\frac{1}{2} \pi}\left\{\left(S \Delta \beta_{i}^{m}\right)^{\prime} S\left[\left(\widehat{\sigma}_{i m}^{2} T\right)^{-1} \sum_{t=1}^{T} X_{i t}^{m} X_{i t}^{m \prime}\right] S^{\prime}\left(S \Delta \beta_{i}^{m}\right)\right\}^{-1}
$$

where $c_{\frac{1}{2} \pi}$ is the $100\left(1-\frac{\pi}{2}\right)$-th quantile of the Picard (1985) distribution.

Albeit constructed using limit theorems, the Wald statistic of Eq. (5) and its associated confidence interval around $\widehat{k}_{i}^{m}$ (Eq. (6)) display satisfactory finite-sample properties. Indeed, according to Bai et al. (1998) and Bekaert et al. (2002), these tests perform adequately, in terms of both size and power, under the null hypothesis of no break and the alternative hypothesis either of a single break in the mean of the DGP or of structural breaks in the coefficients of exogenous regressors, as in the general model of Eq. (3).

\section{Data}

The basic dataset we use in this paper consists of weekly, continuously compounded, dividendadjusted, U.S. dollar returns for all the Level II and Level III ADR stocks $(i)$ traded at the NYSE,

\footnotetext{
${ }^{11}$ To compute these critical values, Bai et al. (1998) suggest to approximate the limiting distribution of $F_{i}^{m}\left(\widehat{k}_{i}^{m}\right)$ with partial sums of normal random variables for each possible rank of the selection matrix $S$ in Eq. (3). Bekaert et al. (2002) report a table with critical values for up to 68 parameters allowed to break, which we use in the analysis that follows.

${ }^{12}$ Bai et al. (1998) review the available literature on the topic.
} 
NASDAQ, or AMEX $\left(r_{i t}^{U S}\right)$, as of April 1, 2003, and their domestic counterparties $\left(r_{i t}^{m}\right)$ traded in emerging financial markets $(m)$. The list of all such issuers is available on the Bank of New York (BoNY)'s website. ${ }^{13}$ Level II and Level III ADRs require basic to full compliance with U.S. GAAP and SEC disclosure rules. We define as emerging economies the 26 countries included in the MSCI Emerging Markets Free Index (EMF), as of April 1, 2003, plus Hong Kong. ${ }^{14}$ We ignore stocks for which no information on their trading venue was provided by BoNY, Level 1 ADRs, and Rule 144A (also known as RADRs). Those stocks, which require only minimal or no compliance with U.S. GAAP nor SEC disclosure, are in fact traded on the OTC (Over The Counter) or the PORTAL (Private Offerings, Resales, and Trading through Automated Linkages) systems with much less liquidity than exchange-listed securities (e.g., Karolyi, 1998). We also ignore companies whose domestic and ADR shares had a short common trading history (100 weeks or less).

This filtering reduces our sample to joint time series of $r_{i t}^{m}$ and $r_{i t}^{U S}$, generally from inception to April 1, 2003, for 156 stocks in 20 countries. These countries are: Argentina, Brazil, Chile, China, Colombia, Hong Kong, Hungary, India, Indonesia, Israel, Mexico, Peru, Philippines, Poland, Russia, South Africa, South Korea, Taiwan, Turkey, and Venezuela. All pricing data were obtained from Datastream. We use weekly returns to control for market microstructure frictions and non-synchronous trading across stock markets, which often plague emerging ADR data at higher frequencies, while still allowing for intra-month price dynamics. ${ }^{15}$ Our database also includes weekly time series of three-month Treasury Bill rates $\left(r_{R F t}^{U S}\right)$ and of dollar returns of broad market indexes for each of the 20 emerging countries $\left(r_{M t}^{m}\right)$ and the U.S. $\left(r_{M t}^{U S}\right)$, again from Datastream. The companies entering these indexes are selected on the basis of their market capitalization and data availability considerations. Factors like liquidity or cross-holdings are therefore ignored. Datastream also excludes from those indexes such securities as unit trusts, mutual and investment funds, and foreign listings (including ADRs).

\footnotetext{
${ }^{13} \mathrm{Http}: / /$ www.adrbny.com/dr_directory.jsp.

${ }^{14} \mathrm{Http}: / /$ www.msci.com/licensing/derive.html. We add Hong Kong to the MSCI list because of the presence of many Chinese companies in that stock exchange.

${ }^{15}$ E.g., Aggarwal et al. (1999). When studying the wedge between Argentine ADRs and their local shares, Auguste et al. (2003) take weekly averages of daily ADR discounts. Higher frequency data is in fact more likely to be affected by stale prices, bid-ask bounce, and non-overlapping trading hours for the emerging and U.S. stock markets. Results based on lower frequencies (e.g., monthly) are qualitatively similar and are available upon request.
} 


\section{$5 \quad$ Estimating regime shifts}

The first objective of this study is to test whether the efficiency and pricing models for ADRs described in Section 2 experience a regime shift in proximity of financial crises. To that purpose, we apply the methodology of Bai et al. (1998) to Eqs. (1) and (2) for each of the 156 ADR stocks in our sample of 20 emerging markets. ${ }^{16}$ Tables 1a and 2a report the resulting regression coefficients from the estimation of both models at the break dates deemed significant according to the Wald statistic of Eq. (5). To provide a benchmark for comparison, we also report country average estimates of Eqs. (1) and (2) for the ADRs that did not experience any such break in Tables $1 \mathrm{~b}$ and $2 \mathrm{~b}$, respectively.

As an example of the analysis underlying these tables, Figure 1 displays the dynamics of $F_{i}^{m}(k)$ for four of the companies in our database. The estimated break date $\widehat{k}_{i}^{m}=\arg \max F_{i}^{m}(k)$ is statistically significant (at the $5 \%$ level) only when the corresponding measure $F_{i}^{m}\left(\widehat{k}_{i}^{m}\right) \geq$ 11.78, the asymptotic $95 \%$ critical value when the rank of $S$ in Eq. (3) is equal to 2 (from Table 10 in Bekaert et al., 2002), i.e., when both coefficients in Eqs. (1) or (2) are allowed to break simultaneously. This is the case for the efficiency model for PT Indonesia Satellite Corporation of Indonesia (Figure 1a) on the fourth week of August 1998 and the pricing model for Grupo Industrial Maseca of Mexico (Figure 1c) on the first week of October 1998. ${ }^{17}$ No statistically significant break is instead registered for Eq. (1) in the case of Banco Bradesco of Brazil (Figure 1b) and for Eq. (2) in the case of Harmony Gold Mining Company of South Africa (Figure 1d).

The evidence in Table 1a suggests that a majority of the depositary receipts in our sample experienced a regime shift in their basic arbitrage relationships during the past decade. Indeed, we find that a statistically (and economically) significant break occurred in the parameters of Eq. (1) for 81 of the 156 emerging market ADRs described in Section 4. These breaks are due on average to decreased dependence of the ADRs' dollar returns $\left(r_{i t}^{U S}\right)$ on the dollar return for the underlying shares in the local market $\left(r_{i t}^{m}\right)$, i.e., $\widehat{\Delta b_{i}}<0$ on average. Consistently, there is greater support for the null hypothesis of perfect substitutability between ADRs and local stocks when the Wald statistics $F_{i}^{m}(k)$ did not register any break: Estimates for $b_{i}\left(a_{i}\right)$ in Table $1 \mathrm{~b}$ are in fact much greater (smaller), and not statistically different from one (zero) more often than in Table 1a. Further, most of the estimated breaks took place around the time of the latest episodes of

\footnotetext{
${ }^{16}$ The correlations between $r_{M t}^{U S}$ and each of the local aggregate return series $r_{M t}^{m}$ are relatively low, ranging from a minimum of 0.07 versus India to a maximum of 0.37 versus Mexico. Therefore, when we estimate Eq. (2), we do not orthogonalize the regressors $r_{M t}^{m}$, as is instead done in Auguste et al. (2003).

${ }^{17}$ The 5\% confidence interval from Eq. (6) is between March 31, 1998 and January 19, 1999 for the former, and between January 6, 1998 and July 6, 1999 for the latter.
} 
financial turmoil. The scatter plots of estimated break dates in Figure 2a show that regime shifts in Eq. (1) cluster during the events of Mexico (1994), East Asia (1997), Russia (1998), Brazil (1999), and Argentina (2002). Hence, many of the recent financial crises involving emerging economies were accompanied by lower efficiency in the ADR market, especially in Argentina, Chile, Mexico, South Africa, and Venezuela. ${ }^{18}$ Average confidence intervals around those dates (computed using Eq. (6) and reported in Table 1a) are also generally tighter (except in Chile), ranging between 3 and 18 months.

The analysis at the country level presents, however, a less homogeneous picture. Table 1a reveals in fact that many estimated realignments were in the direction of the law of one price: The average shift $\widehat{\widehat{\Delta b}_{i}}$ is actually positive, pushing $b_{i}$ toward one, for 9 of the 16 countries (and for 42 of the 81 companies) where we found statistically significant breaks in Eq. (1), most notably in Brazil, China, India, and Russia. Yet, the average relative deterioration of the law of one price (i.e., with respect to $\widehat{b}_{i}$ when $\widehat{\Delta b}_{i}<0$ ) amounts to a considerable $54.13 \%$. In addition, efficiency breaks for Brazilian and Argentine ADRs are concentrated in the latter part of the sample, while substitutability between depositary receipts from Mexican, Chilean, and Korean issuers and their underlying local stocks declined throughout the 1990s (see Figure 2a).

According to Figure 2b, many of these arbitrage breaks were associated with statistically significant regime shifts in the relationship between excess ADR dollar returns and domestic and global sources of risk (Eq. (2)). In particular, $F_{i}^{m}\left(\widehat{k}_{i}^{m}\right) \geq 11.78$ for 54 of the 81 companies for which the corresponding Wald statistic was significant as well in Table 1a. Further, Table 2a reports that $\Delta \widehat{b}_{i}^{m}$ is positive on average for 79 ADRs, and positive and economically significant in 9 of the 15 countries in our sample for which at least one regime shift in Eq. (2) was found (for a median relative increase of $109.05 \%$ with respect to $\left.\widehat{b}_{i}^{m}\right) \cdot{ }^{19}$ Therefore, not only was the market for emerging ADRs generally less efficient, but also local market returns became more relevant to their pricing in proximity of financial crises. When compared to the benchmark estimates of Table $2 \mathrm{~b}$, this evidence suggests that, with few exceptions (e.g., Argentina and Venezuela), most recent episodes of financial turmoil entailed more intense generation of information in the less liquid local markets of emerging economies than in the U.S. stock markets. The lower covariance of ADR returns with world factors $\left(\Delta \widehat{b}_{i}^{U S}<0\right.$ on average and for 8 countries in Table $2 \mathrm{~b}$, for a median relative decline of $137.07 \%$ with respect to $\widehat{b}_{i}^{U S}$ ) indicates that many emerging equity

\footnotetext{
${ }^{18}$ Consistently, Hunter (2005) finds evidence of deteriorating efficiency in the ADR markets of Argentina, Chile, and Mexico during crisis periods.

${ }^{19}$ As to Table $2 \mathrm{~b}$, the estimated pricing break dates $\widehat{k}_{i}^{m}$ in Figure $2 \mathrm{~b}$ are also characterized by generally wider confidence intervals (albeit more homogeneously so) than those surrounding the efficiency break dates in Figure 2a (reported in Table 1a).
} 
markets became less integrated and capital flows less mobile during those events, as argued in Sections 1 and 2. Yet, in contrast to Figure 2a, Figure 2b also reveals that pricing breaks tend to cluster in geographical patterns as well, especially in Latin America. For example, most shifts to Eq. (2) took place in late 1994 for Mexican issuers, in 1999 for Brazilian issuers, and in 2001 for Argentine issuers.

\section{$6 \quad$ Explaining regime shifts}

Based on the evidence presented in the previous section, we conclude that periods of financial stress make the market for emerging ADRs, on average, less efficient, more segmented, and more sensitive to local sources of risk than in more tranquil times. In particular, we learned from Figure 2 that most of the statistically significant regime shifts in the efficiency and pricing relationships for ADRs described in Section 2 concentrate in the winter of 1994 (at the time of the Mexican peso crisis), in the second half of 1997 (during the turmoil in East Asia), in the summer of 1998 (in correspondence with the collapse of the ruble and the LTCM debacle), in the first few months of 1999 (at once with the Brazilian fiscal crisis), and lastly at the end of 2001 (when Argentina defaulted on its sovereign debt). Nonetheless, we also found a significant degree of heterogeneity in the response of each country's ADRs to those shocks.

In short, these results seem to suggest that protracted periods of economic and financial instability did indeed translate into important shifts in the efficiency of emerging capital markets and meaningful realignments of the pricing factors driving their dynamics. In the remainder of the paper, we intend to explain why these shifts took place during the many crises occurred in the last decade. To that purpose, we introduce some new variables. The first is $E_{t}^{m}$, the number of companies in country $m$ whose ADRs are experiencing a statistically significant permanent break in the efficiency relationship of Eq. (1) at time $t$; more specifically, $E_{t}^{m}$ is computed as the number of ADRs for country $m$ for which $t$ is greater than or equal to the lower band of their confidence interval around $\widehat{k}_{i}^{m}$, where $F_{i}^{m}\left(\widehat{k}_{i}^{m}\right) \geq 11.78 .{ }^{20}$ Hence, $E_{t}^{m}$ measures the extent of concentration and persistence of efficiency break events across all ADRs in country $m$ for each period $t$. Similarly, we define $P_{t}^{m}$ as the number of companies in country $m$ whose ADRs are experiencing a statistically significant break in the pricing relationship of Eq. (2) at time $t$. As an example, Figure 3 displays plots of $E_{t}^{m}$ for China and South Korea, and of $P_{t}^{m}$ for Argentina and Mexico. Our objective is to explain the behavior of $E_{t}^{m}$ and $P_{t}^{m}$ for each of the countries in

\footnotetext{
${ }^{20}$ Thus, $E_{t}^{m}=\sum_{i=1}^{N(m)} d_{t}\left(\widehat{k}_{i}^{m-}\right)$, where $\widehat{k}_{i}^{m-}=\widehat{k}_{i}^{m}-c_{\frac{1}{2} \pi}\left\{\left(S \Delta \beta_{i}^{m}\right)^{\prime} S\left[\left(\widehat{\sigma}_{i m}^{2} T\right)^{-1} \sum_{t=1}^{T} X_{i t}^{m} X_{i t}^{m \prime}\right] S^{\prime}\left(S \Delta \beta_{i}^{m}\right)\right\}^{-1}$
} is the lower bound of the confidence interval for $\widehat{k}_{i}^{m}$ (Eq. (6)) and $N(m)$ is the number of ADRs for country $m$. 
our sample.

There is an increasing body of theoretical and empirical studies attempting to explain why financial crises occur and how they manifest. ${ }^{21}$ Local macroeconomic and microeconomic weaknesses, market failures, or the seemingly irrational behavior of traders and speculators are among the most plausible and frequently mentioned interpretations of those phenomena. Fiscal or trade imbalances (e.g., Eichengreen et al., 1996), high levels of dollar-denominated corporate borrowing (e.g., Thurow, 1998), or political instability may all make the domestic economy and financial markets more vulnerable to external and internal shocks, as well as to speculative attacks. Excessive volatility and comovement or shrinking liquidity have also been related to the occurrence of contagious financial crises. In particular, many papers have argued that the trading activity of (foreign or domestic) investors or speculators contribute to destabilize local equity markets (e.g., Choe et al., 1999; Kyle and Xiong, 2001; Kodres and Pritsker, 2002; Pasquariello, 2004; Yuan, 2005). There is also some agreement that the interaction of stock and foreign exchange markets plays a crucial role in those crises (Corsetti et al., 1998; Park and Lee, 2001). Finally, financial market crises may be self-fulfilling (e.g., Obstfeld, 1998) or stem from the (rational or "irrational") behavior of hedge funds, pension funds, and mutual funds. ${ }^{22}$

We want to determine the relevance of these considerations in explaining the clustering and dynamics of efficiency and pricing shifts for emerging ADRs in proximity of episodes of financial turmoil. To accomplish this task, we consider a number of proxies for those arguments which can be grouped into seven categories: Information, trend, economic environment, financial integration, investors' activity, market liquidity, and expected returns.

\subsection{Information}

The first group contains financial variables related to information. It is often argued that information asymmetry and heterogeneity among investors contribute to the occurrence, severity, and propagation of financial crises. ${ }^{23}$ Time-varying uncertainty and disagreement may also explain the adjustment in the relative importance of local sources of risk in ADR returns. We use domestic and U.S. market return volatility $\left(\sigma_{t}^{m}\right.$ and $\left.\sigma_{t}^{U S}\right)$, computed as the standard deviation of weekly returns for the corresponding index in local currency ( $R_{M t}^{m}$ and $r_{M t}^{U S}$ from Datastream) over the past 100 weeks, as (albeit imperfect) ex post proxies for both the level of market-wide

\footnotetext{
${ }^{21}$ See Calomiris (1995) and Kallberg et al. (2005) for an overview.

${ }^{22}$ See, for example, Brown et al. (1998), Eichengreen and Mathieson (1998), Kaminsky et al. (2000, 2001), Disyatat and Gelos (2001), and Kim and Wei (2002).

${ }^{23}$ Pasquariello (2004) reviews this literature.
} 
confusion and the degree of disagreement among investors with respect to asset valuations at time $t$.

\subsection{Trend}

Generalized purchases or sales of assets within a market, motivated either by imitation, injections and redemptions of cash in mutual funds, the activity of momentum fund managers, or by rational or irrational bubbles, may also alter the link between ADR prices and their underlying assets. However, the effects of these activities on the efficiency and pricing of ADRs would differ depending on the direction of the ensuing trends in the financial markets involved. Indeed, Kyle and Xiong (2001) and Yuan (2005) have argued that financial crises are more likely to occur when short-selling, borrowing, and wealth constraints induce rational speculators to trade regardless of fundamentals. The main implication of these arguments is that violations of the arbitrage relation of Eq. (1) or shifts in the relative importance of local or global sources of risk for ADR returns should be more likely during a bear market or a correction, i.e., when those financial constraints are more binding for investors. The second group of variables therefore attempts to measure prolonged, asymmetric runs in the aggregate domestic and U.S. return series. More specifically, we devise two sets of dummy measures $d_{t}^{m+}$ and $d_{t}^{m-}$ (and $d_{t}^{U S+}$ and $d_{t}^{U S-}$ ) equal to one if the sign of $R_{M t}^{m}\left(r_{M t}^{U S}\right)$ over the current and each of the previous two weeks is positive or negative, respectively, and equal to zero otherwise.

\subsection{Economic environment}

Our third group of variables provides information on the dynamics of the local and U.S. economic environment. Many recent financial crises were ignited by pressures on the domestic currency. Bailey et al. (2000), Pavlova and Rigobon (2003), and Kallberg et al. (2005), among others, explicitly studied the empirical and theoretical relation between currency and equity markets in proximity of episodes of financial turmoil. Instability in the exchange rate market may affect both Eqs. (1) and (2) either directly (when altering the terms of trade between ADRs and underlying assets) or indirectly (by virtue of its impact on the domestic and U.S. stock markets).

In this paper, we use the standard deviation of weekly returns for the exchange rate between the domestic currency for country $m$ and the dollar $\left(r_{m t}^{F X}\right.$ from Datastream) over the past 100 weeks, $\sigma_{m t}^{F X}$, to measure the stability of that country's foreign exchange market. Not only the volatility of the exchange rate, but its direction may be relevant as well. Emerging economies, and their ADRs, may in fact react differently to continuing appreciation or depreciation of the 
domestic currency, depending on their exposure to foreign currency-denominated debt, their dependence on imports, or the importance of foreign markets for their products and services. To account for this possibility, we introduce an additional set of dummies equal to one if the local currency has been depreciating $\left(d_{m t}^{F X+}\right)$ or appreciating $\left(d_{m t}^{F X-}\right)$ versus the dollar (i.e., if the relative change in the exchange rate $r_{m t}^{F X}$ is positive or negative) over the current and each of the previous two weeks and equal to zero otherwise.

The degree of economic integration of a country is also going to affect its sensitivity to fluctuations of the exchange rate. As in Bekaert et al. (2002), we proxy for it with monthly ratios of exports plus imports divided by GDP (from IFS), $T_{t}^{m}$, which capture the size of each country $m$ 's trade sector. ${ }^{24}$ Finally, we are interested in measuring how current and expected macroeconomic conditions are going to affect a country's ability to fulfill its obligations toward creditors. Indeed, when these conditions deteriorate, investors tend to move away from its capital markets. We use the foreign currency sovereign credit rating history from Standard \& Poors to construct monthly series $C_{t}^{m}$ of numeric rating shifts (from a high of 26 for AAA to a low of 1 for Default) as an (albeit imprecise) proxy for the ex ante credibility of country $m$ 's economic policies.

\subsection{Financial integration}

Over the past fifteen years, most of the emerging economies in our sample experienced significant regulatory changes which have furthered their financial integration with the rest of the world. As a result of these changes, domestic investors gained access to investments in foreign assets, and foreign investors to domestic assets. This process of market integration has affected expected returns, their correlation with world factors, the cost of capital, and volatility (e.g., Bekaert and Harvey, 1995, 1997, and 2000).

These changes may have affected the market for ADRs as well. More specifically, it is reasonable to imagine that, as a consequence of capital market liberalization, domestic and foreign investors and speculators gained greater access to both depositary receipts and their underlying stocks, thus altering (and possibly realigning) not only the arbitrage relationships between ADR and local prices but also their dependence on local and global sources of risk. To test for the validity of this argument, we therefore need to account for the occurrence of liberalization events in our sample. Measuring and dating the process of market integration represents, however, a very difficult task. Indeed, this process generally involves a series of complex, gradual steps whose rel-

\footnotetext{
${ }^{24}$ Trade linkages may also provide a channel for the occurrence and propagation of financial crises (e.g., Glick and Rose, 1999; Dasgupta, 2000).
} 
ative ultimate impact on the degree of financial market openness of a country is often extremely difficult to assess. Thus, we employ the chronology of financial integration generated by Bekaert and al. (2002), since it measures endogenous market integration rather than exogenous market liberalization. These dates, although usually later than dates of official capital market reforms, result in fact from model-free, non-parametric specifications which nonetheless control for many financial and macroeconomic variables likely related to the integration process. In particular, we define a dummy $I_{t}^{m}$ equal to one if $t$ is greater than (or equal to) the lower bound of the confidence interval for the estimated integration date reported by Bekaert et al. (2002) in the last column of their Table 2 and equal to zero otherwise.

\subsection{Investors' activity}

Grossman and Stiglitz (1980) were the first to observe that speculative trading activity makes capital markets more efficient by augmenting the information content of prices. In that respect, foreign speculators may play an especially important role in emerging markets, where liquidity is often poor, generation, acquisition, and dissemination of information are still insufficiently standardized, and price manipulation is more likely (see Bekaert and Harvey, 2000). Foreign speculators would therefore improve the efficiency of the market for emerging ADRs and affect the contribution of local and global sources of risk to their prices by enhancing their informational and allocational properties.

Foreign investors have, however, also been accused of destabilizing emerging capital markets. Short-term trading by foreign speculators and the portfolio rebalancing activity of institutional investors are frequently blamed by the financial press for exacerbating the propagation of shocks across markets. Moreover, recent empirical evidence (e.g., Kaminsky et al., 2001, 2004) linked redemptions and injections of underlying investors in mutual funds to emerging markets crises. Under this scenario, more intense trading activity by foreign investors in the domestic markets would negatively affect these markets' ability to process information (hence altering the parameters of Eq. (2)) and to ensure that no-arbitrage conditions are satisfied (hence lowering the parameter $b_{i}$ in Eq. (1)).

We test for the validity of these conflicting arguments by introducing a new set of variables, $F_{t}^{m}$, as proxies for signed net trading activity by foreign investors in the emerging equity markets in our sample. In particular, following Tesar and Werner (1995b), we define $F_{t}^{m}$ as the net monthly equity capital flows (in millions of dollars) for country $m$, from the U.S. Treasury Bulletin, for the corresponding week $t$. 


\subsection{Market liquidity}

Our sixth group of variables tries to measure the liquidity in each of the markets where ADRs and underlying stocks are traded. There is some anecdotal evidence that, during financial crises, the number of speculators willing to trade domestic assets dwindles and transaction costs raise, thereby reducing local market liquidity, implicitly limiting arbitrage activities, and moving prices away from fundamentals. For instance, arbitrageurs may find lending shares for shorting more difficult, as Summers (2000, p. 5) notes that, during the major international financial crises of the 1990s, "investors (both domestic and foreign) decided to reduce the stock of their assets in the affected country." In addition, Lesmond (2004) shows that various measures of transaction costs in emerging equity markets increased in proximity of the events in East Asia and Russia. Hence, shrinking liquidity may explain why prices of depositary receipts departed from basic no-arbitrage relations or became more sensitive to global factors. Vice versa, periods of greater market liquidity may translate in higher correlation between $r_{i t}^{U S}$ and $r_{i t}^{m}$ and greater sensitivity of ADR returns to local sources of risk.

In addition, it has been argued that when a security trades at multiple locations, ceteris paribus, insiders would choose to trade in the more liquid venue since the impact of their actions on the equilibrium prices is going to be lower (e.g., Chowdhry and Nanda, 1991). Then, shifts in the relative liquidity of the markets for ADRs and local stocks may affect the relative pricing of those securities and the relative importance of domestic and U.S.-originated information production in $r_{i t}^{U S}$. As in Bekaert et al. (2002), we proxy for the liquidity of the U.S. $\left(L_{t}^{U S}\right)$ and each emerging $\left(L_{t}^{m}\right)$ equity market in our database by computing the ratio of weekly volume of trading to weekly market capitalization, both in local currency, from Datastream.

\subsection{Expected returns}

Finally, we consider the possibility that relative changes in expected returns alter the efficiency and pricing of ADRs. Relative information shocks, the process of market liberalization, or shifts in the investors' perception of (diversifiable and non-diversifiable) local and U.S. risks may sway investors' expectations and preferences for local versus U.S. equities, therefore permanently altering the existing links between domestic, global, and ADR returns. To bring this proposition to the data, we need to estimate expected returns in the markets where depositary receipts and their underlying securities are traded. Bekaert and Harvey (2000) have argued that changes in dividend yields are effective measures for changes in expected returns of emerging capital markets. Hence, we use weekly time series of dividend yields from Datastream to define two new 
sets of variables, $D_{t}^{m}$ and $D_{t}^{U S}$, in each of the emerging markets in our sample and in the U.S. stock market. $^{25}$

\subsection{The analysis}

We now test whether the various proxies devised above can explain the occurrence and clustering of the efficiency and pricing breaks reported in Tables $1 \mathrm{a}$ and $2 \mathrm{a}$ and displayed in Figure 2. To accomplish this task, the simplest approach would be to use multivariate linear regressions. However, because the breaks are, by construction, unique events and concentrate over relatively short periods of time, the discrete dependent variables $E_{t}^{m}$ and $P_{t}^{m}$ show a preponderance of zeros and small values (e.g., in Figure 3). According to the econometric literature, the Poisson regression model is a better specification to account for these properties of the data. This model assumes that each discrete dependent variable $Y_{t}^{m}$ (either $E_{t}^{m}$ or $P_{t}^{m}$ ) is drawn from a Poisson distribution with parameter $\lambda_{t}^{m}$, such that

$$
\operatorname{Pr}\left(Y_{t}^{m}=i\right)=\frac{e^{-\lambda_{t}^{m}}\left(\lambda_{t}^{m}\right)^{i}}{i !}
$$

where $i$ is the number of ADRs in country $m$ experiencing a break in Eq. (1), when $Y_{t}^{m}=E_{t}^{m}$, or in Eq. (2), when $Y_{t}^{m}=P_{t}^{m}$, for $i=0,1,2, \ldots{ }^{26}$ We impose that the parameter $\lambda_{t}^{m}$ is related to our seven groups of regressors in terms of the following log-linear model:

$$
\begin{aligned}
\ln \lambda_{t}^{m}= & \gamma_{1} \sigma_{t}^{m}+\gamma_{2} \sigma_{t}^{U S}+\gamma_{3} d_{t}^{m+}+\gamma_{4} d_{t}^{m-}+\gamma_{5} d_{t}^{U S+}+\gamma_{6} d_{t}^{U S-}+ \\
& \gamma_{7} \sigma_{m t}^{F X}+\gamma_{8} d_{m t}^{F X+}+\gamma_{9} d_{m t}^{F X-}+\gamma_{10} T_{t}^{m}+\gamma_{11} C_{t}^{m}+\gamma_{12} I_{t}^{m}+ \\
& \gamma_{13} F_{t}^{m}+\gamma_{14} L_{t}^{m}+\gamma_{15} L_{t}^{U S}+\gamma_{16} D_{t}^{m}+\gamma_{17} D_{t}^{U S}
\end{aligned}
$$

We estimate the parameters of Eq. (8) by maximum likelihood and report the results in

\footnotetext{
${ }^{25}$ Dividend yields in the U.S. $\left(D_{t}^{U S}\right)$ are characterized by a pronounced downward trend over the sample period, which can be in part ascribed to the increasing popularity of alternative payout policies (e.g., stock repurchases or stock rights) by U.S. corporations. No such trends can be identified for the emerging market dividend yields series $\left(D_{t}^{m}\right)$.

${ }^{26}$ By construction, both time series $E_{t}^{m}$ and $P_{t}^{m}$, as well as their first differences, display high positive serial correlation, thus violating the assumption that event occurrences generated by a Poisson point process in successive time intervals are independent. Unfortunately, alternative time series regression models for counts with those properties are neither available nor very well developed yet (e.g., see the surveys of Cameron and Trivedi, 1996 and Greene, 1997, Chapter 19). Therefore, after balancing the inadequacy of the Poisson model with the inability of least squares and the linear model to account for the discrete nature of the nonnegative dependent variables in Eq. (7), we decided to proceed with the former. The results from multiple linear regressions (available on request) are nonetheless qualitatively similar.
} 
Table 3 for $Y_{t}^{m}=E_{t}^{m}$ and in Table 4 for $Y_{t}^{m}=P_{t}^{m}$ for each emerging country $m$ in our sample. ${ }^{27}$ Our model appears to perform well in both cases. The Poisson model produces no obvious counterpart to the $R^{2}$ of linear regressions. Yet, two alternative measures of goodness of fit based on standardized residuals $\left(R_{P}^{2}\right)$ and log-deviances $\left(R_{D}^{2}\right)$ are both mostly greater than $90 \%$, while the chi-squared statistic $\left(\chi^{2}\right)$ rejects the null hypothesis that the slopes in Eq. (8) are all zero for all countries but Hong Kong and Poland in Table 3 and South Korea in Table 4. Further, our evidence suggests that information asymmetry, domestic and U.S. economic conditions, and changes in relative liquidity and expected returns are the most relevant factors in explaining the clustering of efficiency and pricing breaks over the last decade.

To begin with, we find that the likelihood of an emerging ADR market to become less efficient and its prices more sensitive to local sources of risk is negatively related to domestic equity volatility and positively related to U.S. stock market volatility. More specifically, we find statistically significant (often at the $1 \%$ level) $\widehat{\gamma}_{1}<0$ and/or $\widehat{\gamma}_{2}>0$ in Eq. (8) for those countries (e.g., Argentina, Mexico, Russia, South Africa, South Korea, and Venezuela) whose ADR markets experienced a (statistically significant) deterioration in their efficiency and/or pricing relationships over the sample period, according to Tables 1a and 2a. Indeed, much trading in emerging market equities already takes place on the NYSE, NASDAQ, or AMEX during "tranquil" times. ${ }^{28}$ More trading, especially if informed, may shift toward these more liquid venues during periods of turmoil. Consistently, greater divergence in liquidity (lower $L_{t}^{m}$ and/or higher $L_{t}^{U S}$ ) explains as well the efficiency and pricing breaks in Tables 1a and 2a: $\widehat{\gamma}_{14}<0$ and/or $\widehat{\gamma}_{15}>0$ in Eq. (8). ${ }^{29}$ Hence, greater information asymmetry, uncertainty, and disagreement makes the more liquid U.S. equity market the primary source of risk for ADR returns $r_{i t}^{U S}$ in Eqs. (1) and (2) in proximity of financial crises.

Not surprisingly, the greater the fluctuations in the domestic currency, the more likely are ADR returns to violate the law of one price and to covary less with U.S. equity returns: $\widehat{\gamma}_{7}>0$ in Eq. (8) for $E_{t}^{m}$ and/or $P_{t}^{m}$ for Argentina, Brazil, Mexico, Russia, South Africa, and South Korea, i.e., where $\widehat{\widehat{\Delta b}}_{i}<0, \overline{\Delta \widehat{b}_{i}^{m}}>0$, and/or $\overline{\Delta \widehat{b}_{i}^{U S}}<0$ in Tables 1a and 2a. Along those lines, the coefficient $\widehat{\gamma}_{7}$ is instead negative and significant for China, Hong Kong, India, and

\footnotetext{
${ }^{27}$ For each country $m$, the sample over which Eqs. (7) and (8) are estimated starts on the first potential break date for the ADR with the earliest return data available ( $t_{0}$ in Tables 3 and 4$)$. The specification of Eq. (8) has no constant term to avoid the possibility of collinear regressors in the estimation.

${ }^{28}$ For example, Hargis et al. (1997) report that a significant portion of trading in cross-listed Mexican stocks occurs in the U.S. rather than in Mexico.

${ }^{29}$ Accordingly, Rabinovitch et al. (2003) find that liquidity is the main factor explaining differences in transaction costs associated with ADR arbitrage activities between Argentina and Chile.
} 
Israel, whose ADR markets were found to become more (rather than less) efficient and sensitive to global sources of risk during the 1990s (in Tables 1a and 2a and Figure 2). ${ }^{30}$ However, the impact of the exchange rate on the efficiency and pricing of the emerging equity markets is symmetrically unrelated to its prolonged unidirectional swings: Coefficients for $d_{m t}^{F X+}$ and $d_{m t}^{F X-}$ in Tables 3 and 4 are not statistically different from zero for most of the countries in the sample. A shrinking (expanding) trade sector (lower (higher) $T_{t}^{m}$ ) also led very often to the clustering of negative (positive) shifts in $\widehat{b}_{i}$ and $\widehat{b}_{i}^{U S}$, and/or positive (negative) shifts in $\widehat{b}_{i}^{m}$, especially in Latin America. Yet, deterioration (improvement) in the efficiency and pricing of ADRs are generally less (more) likely to occur during worsening (better) macroeconomic conditions (as proxied by declining S\&P sovereign ratings $C_{t}^{m}$ ): $\widehat{\gamma}_{11}>0$ in Tables 3 and 4 for most countries in the sample. These results indicate that the healthier economic environment of an emerging country and the ensuing attention from the financial community ameliorate the efficiency and pricing of its ADR market only if accompanied by greater economic integration with the rest of the world.

Somehow surprisingly, capital flight, measured by net monthly equity capital flows $\left(F_{t}^{m}\right)$, does not impact the clustering of arbitrage and pricing breaks in emerging ADR markets, with the sole exception of India. The dummy for the process of market liberalization $\left(I_{t}^{m}\right)$ is equally disappointing: It is in fact only for the Philippines that financial integration occurs within the time-frame of our sample. In that circumstance, the opening of its equity market to foreign investors improved its overall efficiency, since the coefficient for $I_{t}^{m}$ in Eq. (8) $\left(\widehat{\gamma}_{12}\right)$ is positive and significant in both Tables 3 and 4 . Thus, the breaks reported in Tables 1a and 2a cannot be explained by inflows and outflows of funds by foreign investors or by the regulatory changes which integrated many emerging capital markets with the rest of the world. Nonetheless, shifts in investors' expectations played an important role for the dynamics of $E_{t}^{m}$ and $P_{t}^{m}$ : Lower expected returns in the U.S. $\left(D_{t}^{U S}\right)$ and in the domestic market $\left(D_{t}^{m}\right)$ almost uniformly increase the likelihood of the law of one price to be violated and of a significant $\Delta \widehat{b}_{i}^{U S}<0$ to be observed. ADR markets were instead on average more efficient, but more sensitive to local sources of risks, in response to higher $D_{t}^{m}$.

In short, our findings suggest that many of the factors usually associated with the occurrence of financial crises in emerging economies, in particular increasing uncertainty and confusion among investors, greater exchange rate volatility, dwindling trade balances, unfavorable expectations, and worsening liquidity (but not financial integration, currency devaluations, or the

\footnotetext{
${ }^{30}$ Since the weekly currency return volatility $\sigma_{m t}^{F X}$ for China, Hong Kong, and India (with a mean of $0.89 \%$, $0.03 \%$, and $0.45 \%$, respectively) is generally smaller than for the other countries in the sample, the corresponding estimates of $\widehat{\gamma}_{7}$ in Table 3 are of greater absolute magnitude.
} 
disruptive flight of foreign capital), also contribute to make their emerging equity markets less efficient and more de facto segmented.

\subsection{Contagion}

The above analysis examined the relation between various fundamental factors linked to the occurrence of financial crises and the occurrence of efficiency and pricing breaks within each emerging ADR market in our sample. There is, however, a growing body of theoretical and empirical literature suggesting that financial crises may propagate across emerging financial markets regardless of those fundamentals. The ensuing financial contagion has often been attributed to the trading activity of investors and speculators, due to either portfolio rebalancing, financial and wealth constraints, or herding. ${ }^{31}$ Multi-asset trading could also increase the likelihood of an emerging country's ADRs to experience regime shifts in their arbitrage and pricing relationships of Eqs. (1) and (2) beyond what would be expected based on the fundamentals described in Sections 6.1 to 6.7 .

To test for this possibility, we construct a novel empirical measure of contagion based on the herding proxy developed by Lakonishok et al. (1992) and used in Wermers (1999) and Kallberg et al. (2005), among others. Indeed, traditional contagion measures, such as return or residual correlation, suffer of various shortcomings (e.g., see Forbes and Rigobon, 2002) and cannot be easily adapted to our discrete framework. We define financial contagion in the context of this study as the circumstance in which the number of emerging ADR markets simultaneously experiencing more efficiency or pricing breaks than justified by the fundamental model of Eqs. (7) and (8) is greater than if due to chance. To make this definition operational, we introduce two new discrete variables $B_{t}(E)=\sum_{m=1}^{n_{t}(E)} \frac{V_{t}^{m}(E)}{n_{t}(E)}$ and $B_{t}(P)=\sum_{m=1}^{n_{t}(P)} \frac{V_{t}^{m}(P)}{n_{t}(P)}$, in which $n_{t}(E) \geq 2$ $\left(n_{t}(P) \geq 2\right)$ is the number of countries $m$ in our sample for which the variable $E_{t}^{m}\left(P_{t}^{m}\right)$ of Section 6 is available at time $t$ and $V_{t}^{m}(E)=1\left(V_{t}^{m}(P)=1\right)$ if $E_{t}^{m}>\hat{\lambda}_{t}^{m}\left(P_{t}^{m}>\hat{\lambda}_{t}^{m}\right)$ and zero otherwise. Hence, $B_{t}(E)\left(B_{t}(P)\right)$ is the fraction of emerging ADR markets experiencing more efficiency (pricing) breaks than expected, given the estimated parameters in Table 3 (Table 4). We then compute our measures of contagious propagation of efficiency and pricing breaks in week $t$ as

$$
C M_{t}(l)=\left\{B_{t}(l)-E\left[B_{t}(l)\right]\right\}-E\left\{B_{t}^{*}(l)-E\left[B_{t}^{*}(l)\right]\right\},
$$

where $l=E$ or $P$. In Eq. (9), we first subtract $E\left[B_{t}(l)\right]$ from $B_{t}(l)$ to allow for variation due

\footnotetext{
${ }^{31}$ Much of this research stems from the seminal work of King and Wadhwani (1990). See Kallberg et al. (2005) for a review of the most recent contributions.
} 
to model mispecification or estimation noise. We then subtract an adjustment term from the resulting observed excess proportion of regime shifts of type $l$ to account for the null hypothesis that contagion is only observed as a result of random chance. More specifically, we calculate this adjustment by assuming that the "normal" number of countries where $E_{t}^{m}>\widehat{\lambda}_{t}^{m}$ (or $P_{t}^{m}>\widehat{\lambda}_{t}^{m}$ ) is drawn from a binomial distribution in which the probability of each such event is one half. ${ }^{32}$

We compute Eq. (9) for both $E_{t}^{m}$ and $P_{t}^{m}$ over selected time intervals by estimating $E\left[B_{t}(l)\right]$ as a rolled average of the past 12 realizations of $B_{t}(l)$, and report the ensuing measures in Table $5 .^{33}$ The results are striking. The variable $C M_{t}(E)$ is not statistically different from zero, and the alternative hypothesis of contagion $H_{1}: C M_{t}(E)>0$ is overwhelmingly rejected in favor of the null hypothesis $H_{0}: C M_{t}(E) \leq 0$ over the entire sample and each of the given subperiods. When pricing breaks are considered, we cannot reject the alternative hypothesis of contagion at a significance level of $8.58 \%$. Yet, it is only during the Mexican Peso crisis, between January 1994 and December 1995, that both the measure $C M_{t}(P)$ is statistically different from zero (at the $10 \%$ level) and the one-sided $t$-test rejects $H_{0}$ (with a $p$-value of $4.75 \%$ ), i.e., emerging ADRs were experiencing more regime shifts in the pricing relation of Eq. (2) than could be explained by fundamentals and chance. Overall, Table 5 suggests that financial contagion did not significantly contribute to the clustering of efficiency and pricing breaks displayed in Figure 2.

\subsection{Legal environment}

In recent years, the financial literature has witnessed increasing interest in the potential effects of the legal environment for equity trading and holding on asset prices, corporate decision-making, and (ultimately) economic development, especially in emerging markets. ${ }^{34}$ The legal environment may also have significant effects on the efficiency and pricing of the emerging ADR market.

Specifically, the extant set of domestic regulations concerning trading and shareholder protection may explicitly and implicitly limit the activity of arbitrageurs, as well as the investment decisions of foreign and local speculators. For instance, many developing countries restrict foreign ownership of domestic firms (Edison and Warnock, 2003). This may curtail the ability of foreign investors to fully arbitrage price wedges between ADRs and their underlying stocks. ${ }^{35}$

\footnotetext{
${ }^{32}$ This implies that $E\left\{B_{t}^{*}(l)-E\left[B_{t}^{*}(l)\right]\right\}=\sum_{m=0}^{n_{t}(l)} \frac{m-0.5}{n_{t}(l)}\left(\begin{array}{c}n_{t}(l) \\ m\end{array}\right) 0.5^{n_{t}(l)\left[n_{t}(l)-m\right]}=0$.

${ }^{33}$ Rolling intervals of different length did not significantly affect the results.

${ }^{34}$ An incomplete list of such studies includes La Porta et al. (1997, 1998), Levine (1998), Stulz (1999), Henry (2000), Beck and Levine (2002), Claessens et al. (2002), and Durnev and Kim (2005).

${ }^{35}$ For example, the circumstances leading to a financial crisis may worsen those traders' existing agency problems. Accordingly, De Long et al. (1990) and Shleifer and Vishny (1997) suggest that random shocks causing undiversifiable risk to arbitrageurs may limit the amount of capital they employ in their trading activity.
} 
Furthermore, ADRs and their associated shares often provide different degrees of protection to their holders. ${ }^{36}$ In the presence of imperfect legal substitutability between the two securities, informed risk arbitrage in emerging markets may become less attractive (Morck et al., 2000). ${ }^{37}$ In times of financial crises, these considerations may become even more important, leading to larger violations of the law of one price and greater dependence of ADR prices on local sources of risk. Finally, the intensity of capital controls is often time-varying. As mentioned in Section 6.4 , virtually all the emerging economies in our sample gradually relaxed capital mobility and foreign ownership restrictions over the course of the 1990s. Yet, some of their governments also abruptly reintroduced many of these restrictions in proximity of financial crises, most notably in Argentina between 2001 and 2002. ${ }^{38}$ These dynamics are likely to influence the degree of efficiency and market segmentation of the affected equity markets.

We address these issues in this section. We noted above that deteriorating macroeconomic and market conditions may implicitly heighten existing barriers to the trading activity of foreign investors and arbitrageurs. Therefore, we begin by studying the link between the clustering and dynamics of efficiency and pricing shifts for emerging ADRs during financial crises and the timevarying intensity of barriers to trading and capital flows, after controlling for the seven categories of macroeconomic and financial variables listed in Sections 6.1 to 6.7. To that purpose, we employ two popular country-level measures of capital controls: The Chinn and Ito (2002) index $\left(C I_{t}^{m}\right)$ and the Edison and Warnock (2003) smoothed index $\left(E W_{t}^{m}\right)$. The former improves over binary variables based on the IMF's Annual Report on Exchange Arrangements and Exchange Restrictions by looking at the interaction between capital controls and other restrictions on international transactions. The latter captures the extent to which a market is closed to foreign investors by looking at the share of that market's capitalization made of "investable" stocks. We then estimate country-level regressions of the difference between the actual number of firms in

\footnotetext{
${ }^{36}$ E.g., Gagnon and Karolyi (2004, p. 10) observe that "depending on the country of origin, the bundle of rights underpinning an ADR and its home share may be quite different from an arbitrageur's perspective even though the cash-flow rights underpinning each security are exactly the same."

${ }^{37}$ In addition, Aggarwal et al. (2004) find that U.S.-based emerging mutual funds prefer to hold ADRs rather than the underlying domestic stocks when the issuers are from countries with weak investor protection laws relative to the U.S.

${ }^{38}$ Nonetheless, the majority of estimated regime shifts in Eqs. (1) and (2) for Argentina took place before new restrictions to capital flight (described in Auguste et al., 2003 and Levy Yeyati et al., 2004) were announced and implemented. However, our evidence of lower efficiency and segmentation of the Argentine ADR market in 2001 (in Tables 1 and 2 and Figure 2) is consistent with the argument in Melvin (2002) that domestic investors moved funds out of Argentina, despite stringent capital controls, by purchasing shares of local companies cross-listed in the U.S. and then converting them in ADRs, until such conversions were permitted (March 25, 2002).
} 
country $m$ experiencing either an efficiency $\left(Y_{t}^{m}=E_{t}^{m}\right)$ or a pricing $\left(Y_{t}^{m}=P_{t}^{m}\right)$ break at time $t$ and the corresponding estimate from the fundamental model of Eqs. (7) and $(8), \hat{\lambda}_{t}^{m}$, on the first differences of both indexes $\left(\Delta C I_{t}^{m}\right.$ and $\left.\Delta E W_{t}^{m}\right)$ as follows:

$$
Y_{t}^{m}-\widehat{\lambda}_{t}^{m}=\delta_{0}^{m}+\delta_{1}^{m} \Delta C I_{t}^{m}+\delta_{2}^{m} \Delta E W_{t}^{m}+u_{t}^{m} .
$$

We adjust each index so that a positive change reflects more intense capital controls, as in Auguste et al. (2003). Therefore, positive estimated values for either $\delta_{1}^{m}$ or $\delta_{2}^{m}$ would indicate that, in country $m$, more efficiency and/or pricing breaks than predicted by the fundamental model of Section 6.8 took place when capital controls intensified. We report these estimates and their statistical significance in Table $6 .{ }^{39}$ The ensuing evidence is mixed. Indeed, either $\delta_{1}^{m}$ or $\delta_{2}^{m}$ are positive and (often just weakly) significant for just few of the countries in our sample, notably only in Russia and South Africa for both efficiency and pricing breaks. In many more countries (e.g., Indonesia, Philippines, South Korea, and Venezuela), those coefficients are instead negative and strongly significant. These results suggest that structural shifts in ADR efficiency and pricing relationships are more likely when the activity of investors and arbitrageurs is less (and not more) hindered.

Next, we test whether poor investor protection and corporate governance in a country contribute to lower efficiency and greater segmentation of its ADR market in proximity of financial crises. To that end, we measure the degree of legal and factual protection each country offers to corporate shareholders using the static country rankings for legal enforcement of investor protection developed by La Porta et al. (1998) - Efficiency of judicial system, Rule of law, Corruption, Risk of expropriation, Risk of contract repudiation, and Rating on accounting standards - as well as the static corporate governance macro rankings and firm-level scores developed by Credit Lyonnais Securities Asia (CLSA) - Rules and regulations, Enforcement and regulation, Political/regulatory environment, Adoption of IGAAP, Institutional mechanisms and corporate governance culture, and their Weighted index — when available. ${ }^{40}$

We then estimate the cross-country covariation between the percentage of ADRs experiencing either efficiency $(e f f)$ or pricing $(p r i)$ breaks in a country $\left(N^{*} / N\right.$ from Tables 1a and 2a, respectively) and the corresponding investor protection rankings. We use three measures of covariation: Pearson parametric correlation $\left(\rho_{\text {eff }}\right.$ and $\left.\rho_{\text {pri }}\right)$, Spearman rank-order correlation $\left(\rho_{\text {eff }}^{s p}\right.$

\footnotetext{
${ }^{39}$ Due to data availability, Eq. (10) can be estimated only until December 2000 and only for 15 of the 20 countries in our sample. We obtain qualitatively similar results when employing index levels.

${ }^{40}$ There is an extensive literature employing the rankings in La Porta et al. (1998). Recent studies of the importance of corporate governance for pricing in emerging markets using the CLSA indexes include Klapper and Love (2002) and Durnev and Kim (2005). CLSA firm scores are available for roughly half of the ADR issuers in 14 of the 20 countries in our sample.
} 
and $\left.\rho_{p r i}^{s p}\right)$, and Pearson partial correlations $\left(r_{e f f}\right.$ and $\left.r_{p r i}\right)$. For all the variables listed above, the higher is the ranking of a country, the greater is its degree of investor protection. Hence, if poorer investor protection explicitly or implicitly limits the trading activity of foreign investors and arbitrageurs in the ADR market, we expect these correlation coefficients to be negative. Their estimates, reported in Table 7, only weakly support this argument. All of the estimated correlations are in fact negative, yet most are statistically indistinguishable from zero or even positive after controlling for multicollinearity.

Finally, we test whether the relative quality of corporate governance of an issuer $i$ within a country $m$ affects the likelihood of its ADR to experience either an efficiency $\left(Y_{i}^{m}=E_{i}^{m}=1\right)$ or a pricing $\left(Y_{i}^{m}=P_{i}^{m}=1\right)$ break over the sample period. We do so by estimating different variants of the following logit model

$$
\operatorname{Pr}\left(Y_{i}^{m}=1\right)=\frac{e^{\alpha+\beta C G_{i}^{m}}}{1+e^{\alpha+\beta C G_{i}^{m}}}
$$

where $C G_{i}^{m}$ is the ratio between CLSA's corporate governance weighted index for firm $i$ in country $m$ and country $m$ 's mean index, as in Klapper and Love (2002). In particular, we alternatively allow for fixed and random country effects, impose exponential heteroskedasticity, or use the number of ADRs for which the index was available in each country as a weighting variable. According to the above considerations, poorer (relative) corporate governance of a firm (lower score $C G_{i}^{m}$ ) should make foreign or domestic speculators less willing to trade its stocks during financial crises, hence its ADR's efficiency and pricing relationships more likely to experience a regime shift: $\beta<0$. Nonetheless, the resulting estimates, in Table 8 , univocally reject this hypothesis: Most of the $\beta$ coefficients are positive, and none of them is statistically significant. ${ }^{41}$ Overall, the evidence reported in this section provides little or no support to the notion that the violations of normal market conditions in proximity of recent financial crises estimated in Section 5 were driven by the extant or worsening legal environment for foreign investors and arbitrageurs.

\section{Conclusions}

Financial crises have received increasing attention from the financial literature, not least in light of the tremendous social and allocational costs stemming from their occurrence. However, determining the nature of a financial crisis has not become as important and distinct an object of study as examining its consequences. Episodes of financial turmoil, especially in emerging

\footnotetext{
${ }^{41}$ Probit models generate qualitatively similar results, available on request.
} 
economies, are instead often defined in terms of those consequences (abrupt price declines, currency devaluations, capital flight) rather than by the market breakdowns that the word "crisis" seems to imply. A clear understanding of the mechanisms by which these events take place is necessary to provide policy-makers with tools and recommendations on how to prevent them from happening in the future.

The main objective of this paper was to contribute to closing this gap. To that purpose, we conducted an empirical investigation of the efficiency and pricing of the emerging ADR market. More specifically, we first identified two fundamental relationships that arbitrage considerations impose on returns of depositary receipts and their local counterparts. The first one, between the dollar return for an ADR and the dollar return for the underlying security, arises from the law of one price, ceteris paribus for various financial frictions, and should always hold unless "normal" market conditions are violated. The second one, between ADR returns and global sources of risk, is the result of perfectly open and fully integrated financial markets. Then, we tested for a regime shift in each of these relations in our sample of ADRs from issuers in 20 emerging countries using the non-parametric technique of Bai et al. (1998).

We provided evidence that, during recent episodes of financial turmoil (Mexico (1994), East Asia (1997), Russia (1998), Brazil (1999), and Argentina (2002)), those normal market conditions were in fact violated. Therefore, our evidence suggests that such episodes were not the result of natural dependencies, but indeed "crises." In particular, we found that a majority of the depositary receipts in our sample experienced statistically and economically significant structural shifts in their efficiency and pricing relationships over the past decade. The estimated chronology of these breaks suggests that financial crises involving emerging economies were accompanied by lower efficiency in the ADR market, greater market segmentation, and more intense generation of information in the less liquid local markets.

Finally, using several regression models, we offered support for some of the available explanations of financial crises in emerging economies, by showing that the estimated regime shifts in each country in our sample were more likely when uncertainty among (foreign) investors was greater and both financial and macroeconomic conditions were deteriorating. Yet, those efficiency and pricing breaks were also generally unrelated to financial contagion, currency depreciations, capital flight, and the legal environment in which equity trading and holding take place. 


\section{References}

[1] Aggarwal, R., Inclan, C., Leal, R. (1999). Volatility in Emerging Stock Markets. Journal of Financial and Quantitative Analysis, 34, pp. 33-55.

[2] Alexander, G., Eun, C., Janakiramanan, S. (1987). Asset Pricing and Dual Listing on Foreign Capital Markets: A Note. Journal of Finance, 42, pp. 151-158.

[3] Auguste, S., Dominguez, K., Kamil, H., Tesar, L. (2003). Cross-Border Trading as a Mechanism for Capital Flight: ADRs and the Argentine Crisis. Journal of Monetary Economics, forthcoming.

[4] Bacidore, J., Sofianos, G. (2002). Liquidity Provision and Specialist Trading in NYSE-Listed Non-U.S. Stocks. Journal of Financial Economics, 63, pp. 133-158.

[5] Bai, J., Lumsdaine, R., Stock, J. (1998). Testing for and Dating Common Breaks in Multivariate Time Series. Review of Economic Studies, 65, pp. 395-432.

[6] Bailey, W., Chan, K., Chung, P. (2002). Depositary Receipts, Country Funds, and the Peso Crash: The Intraday Evidence. Journal of Finance, 55, pp. 2693-2717.

[7] Beck, T., Levine, R. (2002). Industry Growth and Capital Allocation: Does Having a Market- or Bank-base System Matter? Journal of Financial Economics, 64, pp. 147-180.

[8] Bekaert, G., Harvey, C. (1995). Time-Varying World Market Integration. Journal of Finance, 50, pp. 403-444.

[9] Bekaert, G., Harvey, C. (1997). Emerging Equity Market Volatility. Journal of Financial Economics, 43, pp. 29-78.

[10] Bekaert, G., Harvey, C. (2000). Foreign Speculators and Emerging Equity Markets. Journal of Finance, 55, pp. 565-613.

[11] Bekaert, G., Harvey, C., Lumsdaine, R. (2002). Dating the Integration of World Equity Markets. Journal of Financial Economics, 65, pp. 203-247.

[12] Brown, S., Goetzmann, W., Park, J. (1998). Hedge Funds and the Asian Currency Crisis of 1997. NBER Working Paper No. 6427.

[13] Calomiris, C. (1995). Financial Fragility: Issues and Policy Implications. Journal of Financial Services Research, 9, pp. 241-257. 
[14] Cameron, C., Trivedi, P. (1996). Count Data Models for Financial Data. In Maddala G., Rao, C. (eds.), Handbook of Statistics, Vol. 14, Statistical Methods in Finance, Elsevier, North-Holland, Amsterdam, pp. 363-392.

[15] Chancellor, E. (2000). Devil Take the Hindmost: A History of Financial Speculation. Farrar, Straus, \& Giroux Inc., New York.

[16] Chinn, M., Ito, H. (2002). Capital Account Liberalization, Institutions and Financial Development: Cross-country Evidence, NBER Working Paper No. 8967.

[17] Choe, H., Kho, B., Stulz, R. (1999). Do Foreign Investors Destabilize Stock Markets? The Korean Experience in 1997. Journal of Financial Economics, 54, pp. 227-264.

[18] Chowdhry, B., Nanda, V. (1991). Multimarket Trading and Market Liquidity. Review of Financial Studies, 4, pp. 483-511.

[19] Claessens, S., Djankov, S., Fan, J., Lang, L. (2002). Disentangling the Incentive and Entrenchment Effects of Large Shareholdings. Journal of Finance, 57, pp. 2741-2771.

[20] Corsetti, G., Pesenti, P., Roubini, N. (1999). What Caused the Asian Currency and Financial Crisis? Working Paper, Yale University.

[21] Dasgupta, A. (2000). Regionality Revised: An Examination of the Direction of Spread of Currency Crises. Working Paper, Yale University.

[22] De Long, B., Shleifer, A., Summers, L., Waldmann, R. (1990). Noise Trader Risk in Financial Markets. Journal of Political Economy, 98, pp. 703-738.

[23] Disyatat P., Gelos, G. (2001). The Asset Allocation of Emerging Market Mutual Funds. IMF Working Paper No. 01/111.

[24] Durnev, A., Kim, H. (2005). To Steal or Not to Steal: Firm Attributes, Legal Environment, and Valuation. Journal of Finance, 60, pp. 1461-1493.

[25] Edison, H., Warnock, F. (2003). A Simple Measure of the Intensity of Capital Controls. Journal of Empirical Finance, 10, pp. 81-103.

[26] Eichengreen, B., Mathieson, D. (1998). Hedge Funds and Financial Market Dynamics. IMF Occasional Paper No. 166. 
[27] Eichengreen, B., Rose, A., Wyplosz, C. (1996). Contagious Currency Crises: First Tests. Scandinavian Journal of Economics, 98, pp. 463-484.

[28] Ely, D., Salehizadeh, M. (2001). American Depositary Receipts. An Analysis of International Stock Price Movements. International Review of Financial Analysis, 10, pp. 343-363.

[29] Errunza, V., Losq, E. (1985). International Asset Pricing under Mild Segmentation: Theory and Test. Journal of Finance, 40, pp. 105-124.

[30] Foerster, S., Karolyi, A. (1999). The Effects of Market Segmentation and Investor Recognition on Asset Prices: Evidence from Foreign Stocks Listing in the United States. Journal of Finance, 54, pp. 981-1014.

[31] Gagnon, L., Karolyi, A. (2004). Multi-Market Trading and Arbitrage. Working Paper, Fisher College of Business, Ohio State University.

[32] Glick, R., Rose, A. (1999). Contagion and Trade: Why are Currency Crises Regional? Journal of International Money and Finance, 18, pp. 603-617.

[33] Greene, W. (1997). Econometric Analysis. Prentice Hall, New Jersey.

[34] Griffin, J., Karolyi, A. (1998). Another Look at the Role of the Industrial Structure of Markets for International Diversification Strategies. Journal of Financial Economics, 50, pp. 351-373.

[35] Grossman, S., Stiglitz, J. (1980). On the Impossibility of Informationally Efficient Markets. American Economic Review, 70, pp. 393-408.

[36] Harvey, C. (1995). Predictable Risk and Return in Emerging Markets. Review of Financial Studies, 8, pp. 773-816.

[37] Henry, P. (2000). Stock Market Liberalization, Economic Reform and Emerging Market Equity Prices. Journal of Finance, 55, pp. 529-565.

[38] Heston, S., Rouwenhorst, G. (1994). Does Industrial Structure Explain the Benefits of International Diversification? Journal of Financial Economics, 36, pp. 3-27.

[39] Howe, J., Kelm, K. (1987). The Stock Price Impact of Overseas Listings. Financial Management, 16, pp. 51-56. 
[40] Hunter, D. (2005). What Drives Time Variation in Emerging Market Segmentation? Journal of Financial Research, 28, pp. 261-280.

[41] Ibbotson, R., Brinson, G. (1993). Global Investing. McGraw-Hill, New York.

[42] Jorion, P., Schwartz, E. (1986). Integration versus Segmentation in the Canadian Stock Market. Journal of Finance, 41, pp. 603-616.

[43] Kallberg, J., Liu, C., Pasquariello, P. (2002). An Examination of the Asian Crisis Part II: Information Spillover, Herding, and Regime Shifts. Working Paper, Stern School of Business, New York University.

[44] Kallberg, J., Liu, C., Pasquariello, P. (2005). An Examination of the Asian Crisis: Regime Shifts in Currency and Equity Markets. Journal of Business, 78, pp. 169-211.

[45] Kaminsky, G., Lyons, R., Schmukler, S. (2001). Mutual Fund Investment in Emerging Markets: An Overview. Working Paper, George Washington University.

[46] Kaminsky, G., Lyons, R., Schmukler, S. (2004). Managers, Investors, and Crises: Mutual Fund Strategies in Emerging Markets. Journal of International Economics, 64, pp. 113-134.

[47] Karolyi, A. (1998). Why Do Companies List Shares Abroad?: A Survey of the Evidence and Its Managerial Implications. Financial Markets, Institutions $\&$ Money, 7, pp. 1-60.

[48] Karolyi, A. (2004). The World of Cross-Listings and Cross-Listings of the World: Challenging Conventional Wisdom. Working Paper, Fisher College of Business, Ohio State University.

[49] Kato, K., Linn, S., Schallheim, J. (1991). Are There Arbitrage Opportunities in the Market for American Depositary Receipts? Journal of International Financial Markets, Institutions \& Money, 1, pp. 73-89.

[50] Kim, W., Wei, S. (2002). Foreign Portfolio Investors Before and During a Crisis. Journal of International Economics, 56, pp. 77-96.

[51] King, M., Wadhwani, S. (1990). Transmission of Volatility between Stock Markets. Review of Financial Studies, 3, pp. 5-33.

[52] Klapper, L., Love, I. (2002). Corporate Governance, Investor Protection, and Performance in Emerging Markets, World Bank Working Paper No. 2818. 
[53] Kodres, L., Pritsker, M. (2002). A Rational Expectations Model of Financial Contagion. Journal of Finance, 57, pp. 769-799.

[54] Kyle, A., Xiong, W. (2001). Contagion as a Wealth Effect. Journal of Finance, 56, pp. 1401-1440.

[55] La Porta, R., Lopez de Silanes, F., Shleifer, A., Vishny, R. (1997). Legal Determinants of External Finance. Journal of Finance, 52, pp. 1131-1150.

[56] La Porta, R., Lopez de Silanes, F., Shleifer, A., Vishny, R. (1998). Law and Finance. Journal of Political Economy, 106, pp. 1113-1155.

[57] Lakonishok, J., Shleifer, A., Vishny, R. (1992). The Impact of Institutional Trading on Stock Prices. Journal of Financial Economics, 32, pp. 23-44.

[58] Lesmond, D. (2004). Liquidity of Emerging Markets. Journal of Financial Economics, forthcoming.

[59] Levine, R. (1998). Stock Markets, Banks, and Economic Growth. American Economic Review, 88, pp. 537-558.

[60] Levy Yeyati, E., Schmukler, S., Van Horen, N. (2004). The Price of Inconvertible Deposits: The Stock Market Boom during the Argentine Crisis. Economic Letters, 83, pp. 7-13.

[61] Melvin, M. (2002). A Stock Market Boom during a Financial Crisis? ADRs and Capital Outflows in Argentina. Working Paper, Arizona State University.

[62] Morck, R., Yeung, B., Yu, W. (2000). The Information Content of Stock Markets: Why Do Emerging Markets Have Synchronous Stock Price Movements? Journal of Financial Economics, 58, pp. 215-260.

[63] Obstfeld, M. (1998). The Global Capital Market: Benefactor or Menace. Working Paper, UC Berkeley.

[64] Park, Y., Lee, J. (2001). Recovery and Sustainability in East Asia. NBER Working Paper No. 8373.

[65] Pasquariello, P. (2004). Imperfect Competition, Information Heterogeneity, and Financial Contagion. Working Paper, Ross School of Business at University of Michigan.

[66] Pavlova, A., Rigobon, R. (2003). Asset Prices and Exchange Rates. Working Paper, MIT. 
[67] Picard D. (1985). Testing and Estimating Change-Points in Time Series. Advances in Applied Probability, 176, pp. 841-867.

[68] Quandt, R. (1958). The Estimation of the Parameters of a Linear Regression System Obeying Two Separate Regimes. Journal of the American Statistical Association, 53, pp. 873-880.

[69] Quandt, R. (1960). Tests of the Hypothesis That a Linear Regression System Obeys Two Separate Regimes. Journal of the American Statistical Association, 55, pp. 324-330.

[70] Rabinovitch, R., Silva, A., Susmel, R. (2003). Returns on ADRs and Arbitrage in Emerging Markets. Working Paper, Bauer College of Business, University of Houston.

[71] Roll, R. (1992). Industrial Structure and the Comparative Behavior of International Stock Market Indices. Journal of Finance, 47, pp. 3-42.

[72] Rosenthal, L. (1983). An Empirical Test of the Efficiency of the ADR Market. Journal of Banking and Finance, 7, pp. 17-29.

[73] Shleifer, A., Vishny, R. (1997). The Limits of Arbitrage. Journal of Finance, 52, pp. 35-55.

[74] Solnik, B. (1974). Why Not Diversify Internationally Rather than Domestically? Financial Analyst Journal, 30, pp. 48-54.

[75] Stulz, R. (1999). Globalization, Corporate Finance and the Cost of Capital. Journal of Applied Corporate Finance, 12, pp. 8-25.

[76] Summers, L. (2000). International Financial Crises: Causes, Prevention, and Cures. American Economic Review Papers and Proceedings, 90, pp. 1-16.

[77] Tesar, L., Werner, I. (1995a). Home Bias and High Turnover. Journal of International Money and Finance, 14, pp. 467-492.

[78] Tesar, L., Werner, I. (1995b). U.S. Equity Investment in Emerging Stock Markets. World Bank Economic Review, 9, pp. 109-130.

[79] Thurow, L. (1998). The Collapse and the Cure. The New York Review of Books: February 5.

[80] Velli, J. (1994). American Depositary Receipts: An Overview. Fordham International Law Journal, 17, pp. 38-57. 
[81] Webb, S., Officer, D., Boyd, B. (1995). An Examination of International Equity Markets Using American Depositary Receipts. Journal of Business Finance and Accounting, 22, pp. 415-430.

[82] Wermers, R. (1999). Mutual Fund Herding and the Impact on Stock Prices. Journal of Finance, 54, pp. 581-622.

[83] Yuan, K. (2005). Asymmetric Price Movements and Borrowing Constraints: A REE Model of Crisis, Contagion, and Confusion. Journal of Finance, 60, pp. 379-411. 
Table 1a. Efficiency tests: One break

This table reports mean OLS estimates for Eq. (1) when it experiences a statistically significant break (at the $5 \%$ level) for each country in the sample and, in brackets, the number of ADRs for which they are (not) different from zero (one) at the $5 \%$ level. $R_{a}^{2}$ is the adjusted $R^{2} . N$ is the number of ADRs, while $N^{*}$ is the subset where date $\widehat{k}_{i}^{m}=\arg \max F_{i}^{m}(k)$, the Wald statistic of Eq. (5), and $F_{i}^{m}\left(\widehat{k}_{i}^{m}\right) \geq 11.78 ;{\widehat{k_{i}^{m \pm}}}^{m}$ is the mean width (and subscript standard deviation) of its confidence interval (Eq. (6)) in weeks.

\begin{tabular}{|c|c|c|c|c|c|c|c|c|c|}
\hline & $N$ & $N^{*}$ & $F_{i}^{m}\left(\widehat{k}_{i}^{m}\right)$ & ${\widehat{k_{i}}}_{i}^{m \pm}$ & $\overline{R_{a}^{2}}$ & $\overline{\widehat{a}}_{i}$ & $\widehat{\widehat{b}_{i}}$ & $\widehat{\Delta a}_{i}$ & $\widehat{\Delta b}_{i}$ \\
\hline Total & 156 & 81 & 46.17 & $\begin{array}{c}63 \\
(58)\end{array}$ & $63.35 \%$ & -0.0017 & $\begin{array}{l}0.7124 \\
(73,21)\end{array}$ & $\begin{array}{c}0.0006 \\
(5)\end{array}$ & $\begin{array}{c}-0.0236 \\
(81)\end{array}$ \\
\hline Argentina & 13 & 9 & 74.33 & $\begin{array}{c}33 \\
(19)\end{array}$ & $54.49 \%$ & $\begin{array}{c}-0.0019 \\
(0)\end{array}$ & $\begin{array}{c}0.7754 \\
(8,5)\end{array}$ & $\underset{(0)}{0.0017}$ & $\begin{array}{c}-0.0205 \\
(9)\end{array}$ \\
\hline Brazil & 30 & 12 & 28.68 & $\begin{array}{l}47 \\
(26)\end{array}$ & $75.40 \%$ & $\begin{array}{c}0.0003 \\
(0)\end{array}$ & $\begin{array}{c}0.7726 \\
(11,3)\end{array}$ & $\begin{array}{c}-0.0016 \\
(0)\end{array}$ & $\begin{array}{c}0.1245 \\
(12)\end{array}$ \\
\hline Chile & 19 & 10 & 37.34 & $\begin{array}{l}105 \\
(84)\end{array}$ & $50.34 \%$ & $\begin{array}{c}-0.0008 \\
(0)\end{array}$ & $\begin{array}{c}0.6673 \\
(7,4)\end{array}$ & $\begin{array}{c}-0.0002 \\
(1)\end{array}$ & $\begin{array}{c}-0.0899 \\
(10)\end{array}$ \\
\hline China & 14 & 8 & 25.61 & $\begin{array}{l}54 \\
(36)\end{array}$ & $81.97 \%$ & $\begin{array}{c}-0.0036 \\
(0)\end{array}$ & $\begin{array}{c}0.5884 \\
(7,0)\end{array}$ & $\begin{array}{c}0.0035 \\
(0)\end{array}$ & $\begin{array}{c}0.2853 \\
(8)\end{array}$ \\
\hline Colombia & 1 & 0 & n.a. & n.a. & n.a. & n.a. & n.a. & n.a. & n.a. \\
\hline Hong Kong & 6 & 1 & 17.13 & $\begin{array}{c}42 \\
\text { (n.a.) }\end{array}$ & $59.89 \%$ & $\begin{array}{c}-0.0113 \\
(0)\end{array}$ & $\begin{array}{c}0.5876 \\
(1,0)\end{array}$ & $\underset{(0)}{0.0115}$ & $\begin{array}{c}0.4134 \\
(1)\end{array}$ \\
\hline Hungary & 1 & 0 & n.a. & n.a. & n.a. & n.a. & n.a. & n.a. & n.a. \\
\hline India & 7 & 2 & 39.34 & $\begin{array}{l}20 \\
(8)\end{array}$ & $68.26 \%$ & $\underset{(1)}{0.0143}$ & $\begin{array}{c}0.6578 \\
(1,1)\end{array}$ & $\begin{array}{c}-0.0161 \\
(1)\end{array}$ & $\underset{(2)}{0.1764}$ \\
\hline Indonesia & 2 & 2 & 39.85 & $\begin{array}{c}61 \\
(27)\end{array}$ & $81.29 \%$ & $\begin{array}{c}-0.0034 \\
(0)\end{array}$ & $\begin{array}{c}0.6358 \\
(2,0)\end{array}$ & $\begin{array}{c}0.0038 \\
(0)\end{array}$ & $\begin{array}{c}0.2296 \\
(2)\end{array}$ \\
\hline Israel & 7 & 3 & 40.24 & $\begin{array}{c}65 \\
(39)\end{array}$ & $55.33 \%$ & $\begin{array}{c}0.0021 \\
(0)\end{array}$ & $\begin{array}{c}0.4534 \\
(3,0)\end{array}$ & $\begin{array}{c}-0.0023 \\
(0)\end{array}$ & $\begin{array}{c}0.4275 \\
\quad(3)\end{array}$ \\
\hline Mexico & 27 & 16 & 65.95 & $\begin{array}{c}76 \\
(61)\end{array}$ & $68.12 \%$ & $\begin{array}{c}-0.0018 \\
(2)\end{array}$ & $\begin{array}{c}0.7967 \\
(16,4)\end{array}$ & $\begin{array}{c}-0.0001 \\
\quad(2)\end{array}$ & $\begin{array}{c}-0.1991 \\
(16)\end{array}$ \\
\hline Peru & 2 & 1 & 57.03 & $\begin{array}{c}32 \\
(n . a .)\end{array}$ & $43.59 \%$ & $\begin{array}{c}-0.0014 \\
(0)\end{array}$ & $\begin{array}{c}0.8168 \\
(1,0)\end{array}$ & $\underset{(0)}{0.0044}$ & $\begin{array}{c}-0.5168 \\
(1)\end{array}$ \\
\hline Philippines & 1 & 1 & 13.66 & $\begin{array}{l}298 \\
(\text { n.a. })\end{array}$ & $55.32 \%$ & $\begin{array}{c}0.0012 \\
(0)\end{array}$ & $\underset{(1,0)}{0.7092}$ & $\begin{array}{c}-0.0018 \\
(0)\end{array}$ & $\begin{array}{c}0.1880 \\
(1)\end{array}$ \\
\hline Poland & 1 & 1 & 44.22 & $\begin{array}{c}12 \\
\text { (n.a.) }\end{array}$ & $51.65 \%$ & $\begin{array}{c}-0.0053 \\
(0)\end{array}$ & $\underset{(1,1)}{0.9165}$ & $\begin{array}{c}-0.0134 \\
(0)\end{array}$ & $-\frac{1.1045}{(1)}$ \\
\hline Russia & 3 & 3 & 67.87 & $\begin{array}{l}17 \\
(6)\end{array}$ & $45.29 \%$ & $-\frac{0.0206}{(1)}$ & $\begin{array}{c}0.5409 \\
(3,1)\end{array}$ & $\begin{array}{c}0.0260 \\
(1)\end{array}$ & $\begin{array}{c}0.0487 \\
(3)\end{array}$ \\
\hline S. Africa & 8 & 6 & 29.89 & $\begin{array}{c}57 \\
(44)\end{array}$ & $64.75 \%$ & $\begin{array}{c}-0.0009 \\
(0)\end{array}$ & $\begin{array}{c}0.8259 \\
(5,2)\end{array}$ & $\begin{array}{c}0.0022 \\
(0)\end{array}$ & $-\frac{0.1890}{(6)}$ \\
\hline S. Korea & 6 & 4 & 21.16 & $\begin{array}{c}81 \\
(46)\end{array}$ & $50.37 \%$ & $\begin{array}{c}-0.0027 \\
(0)\end{array}$ & $\begin{array}{c}0.5695 \\
(4,0)\end{array}$ & $\begin{array}{c}-0.0009 \\
(0)\end{array}$ & $\underset{(4)}{0.0416}$ \\
\hline Taiwan & 5 & 0 & n.a. & n.a. & n.a. & n.a. & n.a. & n.a. & n.a. \\
\hline Turkey & 1 & 0 & n.a. & n.a. & n.a. & n.a. & n.a. & n.a. & n.a. \\
\hline Venezuela & 2 & 2 & 107.1 & $\begin{array}{l}44 \\
(57) \\
\end{array}$ & $42.82 \%$ & $\begin{array}{c}0.0025 \\
(0)\end{array}$ & $\begin{array}{c}0.7479 \\
(2,0)\end{array}$ & $\begin{array}{c}-0.0132 \\
(0)\end{array}$ & $\begin{array}{c}-0.8359 \\
(2)\end{array}$ \\
\hline
\end{tabular}


Table 1b. Efficiency tests: No break

This table reports mean OLS estimates for Eq. (1) when it does not experience a statistically significant break (at the $5 \%$ level) for each country in the sample and, in brackets, the number of ADRs for which they are (not) statistically different from zero (one) at the $5 \%$ significance level. Variables and statistics are defined in the notes to Table 1a. $N^{o}$ is the subset of ADRs where date $\widehat{k}_{i}^{m}=\arg \max F_{i}^{m}(k)$, the Wald statistic of Eq. (5), but $F_{i}^{m}\left(\widehat{k}_{i}^{m}\right)<11.78$.

\begin{tabular}{|c|c|c|c|c|c|c|c|c|c|}
\hline & $N$ & $N^{o}$ & $F\left(\widehat{k}_{i}^{m}\right)$ & $\overline{\hat{k}_{i}^{m \pm}}$ & $\overline{R_{a}^{2}}$ & $\overline{\widehat{a}_{i}}$ & $\widehat{\widehat{b}}_{i}$ & $\widehat{\widehat{\Delta a_{i}}}$ & $\widehat{\widehat{\Delta b}}$ \\
\hline Total & 156 & 75 & 5.94 & n.a. & $72.14 \%$ & $\begin{array}{c}-0.0009 \\
(1)\end{array}$ & $\begin{array}{l}0.8734 \\
(73,28)\end{array}$ & n.a. & n.a. \\
\hline Argentina & 13 & 4 & 6.67 & n.a. & $38.06 \%$ & $\begin{array}{c}-0.0039 \\
(0)\end{array}$ & $\begin{array}{c}0.6175 \\
(3,1)\end{array}$ & n.a. & n.a. \\
\hline Brazil & 30 & 18 & 5.74 & n.a. & $84.32 \%$ & $\begin{array}{c}-0.0002 \\
(0)\end{array}$ & $\begin{array}{c}0.9235 \\
(18,6)\end{array}$ & n.a. & n.a. \\
\hline Chile & 19 & 9 & 8.50 & n.a. & $77.50 \%$ & $-\frac{0.0004}{(0)}$ & $\begin{array}{c}0.9205 \\
(9,4)\end{array}$ & n.a. & n.a. \\
\hline China & 14 & 6 & 4.62 & n.a. & $85.29 \%$ & $\begin{array}{c}0.0002 \\
(0)\end{array}$ & $\underset{(6,2)}{0.9112}$ & n.a. & n.a. \\
\hline Colombia & 1 & 1 & 4.81 & n.a. & $4.69 \%$ & $-\frac{0.0029}{(0)}$ & $\begin{array}{c}0.2753 \\
(1,0)\end{array}$ & n.a. & n.a. \\
\hline Hong Kong & 6 & 5 & 5.28 & n.a. & $65.33 \%$ & $\begin{array}{c}-0.0017 \\
(0)\end{array}$ & $\begin{array}{c}0.8516 \\
(5,1)\end{array}$ & n.a. & n.a. \\
\hline Hungary & 1 & 1 & 7.63 & n.a. & $82.65 \%$ & -0.00003 & $\underset{(1,0)}{0.9426}$ & n.a. & n.a. \\
\hline India & 7 & 5 & 5.80 & n.a. & $56.86 \%$ & $\begin{array}{c}-0.0017 \\
(0)\end{array}$ & $\begin{array}{c}0.8151 \\
(5,2)\end{array}$ & n.a. & n.a. \\
\hline Indonesia & 2 & 0 & n.a. & n.a. & n.a. & n.a. & n.a. & n.a. & n.a. \\
\hline Israel & 7 & 4 & 3.86 & n.a. & $80.36 \%$ & $\begin{array}{c}-0.0002 \\
(0)\end{array}$ & $\begin{array}{c}0.9698 \\
(4,3)\end{array}$ & n.a. & n.a. \\
\hline Mexico & 27 & 11 & 6.08 & n.a. & $74.65 \%$ & $\begin{array}{c}-0.0001 \\
(0)\end{array}$ & $\begin{array}{c}0.9218 \\
(11,5)\end{array}$ & n.a. & n.a. \\
\hline Peru & 2 & 1 & 6.87 & n.a. & $-0.61 \%$ & $\begin{array}{c}-0.0147 \\
(1)\end{array}$ & $\begin{array}{c}-0.0023 \\
(0,0)\end{array}$ & n.a. & n.a. \\
\hline Philippines & 1 & 0 & n.a. & n.a. & n.a. & n.a. & n.a. & n.a. & n.a. \\
\hline Poland & 1 & 0 & n.a. & n.a. & n.a. & n.a. & n.a. & n.a. & n.a. \\
\hline Russia & 3 & 0 & n.a. & n.a. & n.a. & n.a. & n.a. & n.a. & n.a. \\
\hline S. Africa & 8 & 2 & 7.28 & n.a. & $63.33 \%$ & $\begin{array}{c}-0.0005 \\
(0)\end{array}$ & $\begin{array}{c}0.8087 \\
(2,0)\end{array}$ & n.a. & n.a. \\
\hline S. Korea & 6 & 2 & 7.03 & n.a. & $71.73 \%$ & $\begin{array}{c}-0.0008 \\
(0)\end{array}$ & $\begin{array}{c}0.8780 \\
(2,0)\end{array}$ & n.a. & n.a. \\
\hline Taiwan & 5 & 5 & 3.98 & n.a. & $70.96 \%$ & $\underset{(0)}{0.0001}$ & $\underset{(5,4)}{0.9718}$ & n.a. & n.a. \\
\hline Turkey & 1 & 1 & 5.89 & n.a. & $66.39 \%$ & $\begin{array}{c}-0.0060 \\
(0)\end{array}$ & $\begin{array}{c}0.8639 \\
(1,0)\end{array}$ & n.a. & n.a. \\
\hline Venezuela & 2 & 0 & n.a. & n.a. & n.a. & n.a. & n.a. & n.a. & n.a. \\
\hline
\end{tabular}


Table 2a. Pricing tests: One break

This table reports mean OLS estimates for Eq. (2) when it experiences a statistically significant break (at the $5 \%$ level) for each country in the sample and, in brackets, the number of ADRs for which they are different from zero at the $5 \%$ level. $R_{a}^{2}$ is the adjusted $R^{2} . N$ is the number of ADRs, while $N^{*}$ is the subset where date $\widehat{k}_{i}^{m}=\arg \max F_{i}^{m}(k)$, the Wald statistic of Eq. (5), and $F_{i}^{m}\left(\widehat{k}_{i}^{m}\right) \geq 11.78 ;{\widehat{k_{i}}}^{ \pm}$is the mean width (and subscript standard deviation) of its confidence interval (Eq. (6)) in weeks.

\begin{tabular}{|c|c|c|c|c|c|c|c|c|c|}
\hline & $N$ & $N^{*}$ & $F\left(\widehat{k}_{i}^{m}\right)$ & $\overline{\widehat{k}_{i}^{m \pm}}$ & $\overline{R_{a}^{2}}$ & $\overline{\widehat{b}_{i}^{m}}$ & $\overline{\widehat{b}_{i}^{U S}}$ & $\overline{\Delta \widehat{b}_{i}^{m}}$ & $\overline{\Delta b_{i}^{U S}}$ \\
\hline Total & 156 & 79 & 28.85 & $\begin{array}{c}71 \\
(53)\end{array}$ & $35.69 \%$ & $\begin{array}{c}0.7538 \\
(71) \\
\end{array}$ & $\begin{array}{c}0.2929 \\
(28) \\
\end{array}$ & $\begin{array}{c}0.1274 \\
(67)\end{array}$ & $\begin{array}{c}-0.0975 \\
(13)\end{array}$ \\
\hline Argentina & 13 & 9 & 49.30 & $\begin{array}{l}55 \\
(50)\end{array}$ & $37.15 \%$ & $\begin{array}{c}0.8061 \\
(9)\end{array}$ & $\begin{array}{c}0.1705 \\
(2)\end{array}$ & $\begin{array}{c}0.0389 \\
(8)\end{array}$ & $\begin{array}{c}0.5965 \\
(5)\end{array}$ \\
\hline Brazil & 30 & 13 & 22.68 & $\begin{array}{l}73 \\
(52)\end{array}$ & $48.90 \%$ & $\begin{array}{c}0.8737 \\
(11)\end{array}$ & $\begin{array}{c}0.3546 \\
(4)\end{array}$ & $\begin{array}{c}0.2853 \\
(12)\end{array}$ & $\begin{array}{c}-0.2850 \\
(4)\end{array}$ \\
\hline Chile & 19 & 11 & 22.29 & $\begin{array}{c}69 \\
(46)\end{array}$ & $25.94 \%$ & $\begin{array}{c}0.6647 \\
(8)\end{array}$ & $\begin{array}{c}0.4580 \\
(5)\end{array}$ & $\begin{array}{c}0.1943 \\
(9)\end{array}$ & $\begin{array}{c}-0.2861 \\
(5)\end{array}$ \\
\hline China & 14 & 8 & 20.62 & $\begin{array}{c}54 \\
(36)\end{array}$ & $24.63 \%$ & $\begin{array}{c}0.5838 \\
(7)\end{array}$ & $\begin{array}{c}-0.0983 \\
(2)\end{array}$ & $\begin{array}{c}0.1151 \\
(7)\end{array}$ & $\begin{array}{c}0.1865 \\
(3)\end{array}$ \\
\hline Colombia & 1 & 0 & n.a. & n.a. & n.a. & n.a. & n.a. & n.a. & n.a. \\
\hline Hong Kong & 6 & 2 & 15.92 & $\begin{array}{c}85 \\
(27)\end{array}$ & $18.45 \%$ & $\begin{array}{c}0.1857 \\
(1)\end{array}$ & $\begin{array}{c}-0.0477 \\
(0)\end{array}$ & $\begin{array}{c}0.6063 \\
(2)\end{array}$ & $\begin{array}{c}0.4988 \\
(1)\end{array}$ \\
\hline Hungary & 1 & 1 & 43.05 & $\begin{array}{c}34 \\
(\text { n.a. })\end{array}$ & $70.87 \%$ & $\begin{array}{c}0.7607 \\
(1)\end{array}$ & $\begin{array}{c}0.1067 \\
(0)\end{array}$ & $\begin{array}{c}0.5046 \\
(1)\end{array}$ & $\begin{array}{c}0.1558 \\
(0)\end{array}$ \\
\hline India & 7 & 2 & 15.56 & $\begin{array}{l}51 \\
(24)\end{array}$ & $31.25 \%$ & $\begin{array}{c}1.2523 \\
(2)\end{array}$ & $\begin{array}{c}-0.8646 \\
(1)\end{array}$ & $-\underset{(1)}{-0.2916}$ & $\begin{array}{c}1.1265 \\
(1)\end{array}$ \\
\hline Indonesia & 2 & 2 & 47.25 & $\begin{array}{c}59 \\
(35)\end{array}$ & $59.17 \%$ & $\begin{array}{c}0.4949 \\
(2)\end{array}$ & $\begin{array}{c}0.2574 \\
(0)\end{array}$ & $\begin{array}{c}0.3809 \\
(2)\end{array}$ & $\begin{array}{c}0.1427 \\
(0)\end{array}$ \\
\hline Israel & 7 & 3 & 15.12 & $\begin{array}{c}79 \\
(47)\end{array}$ & $28.59 \%$ & $\begin{array}{c}0.5593 \\
(3)\end{array}$ & $\begin{array}{c}0.6085 \\
(1)\end{array}$ & $\begin{array}{c}0.5356 \\
(2)\end{array}$ & $\begin{array}{c}-0.4979 \\
(1)\end{array}$ \\
\hline Mexico & 27 & 17 & 26.01 & $\begin{array}{c}69 \\
(38)\end{array}$ & $38.43 \%$ & $\begin{array}{c}0.8675 \\
(16)\end{array}$ & $\begin{array}{c}0.4373 \\
(7)\end{array}$ & $\begin{array}{c}-0.0065 \\
(15)\end{array}$ & $\begin{array}{c}-0.3910 \\
(6)\end{array}$ \\
\hline Peru & 2 & 0 & n.a. & n.a. & n.a. & n.a. & n.a. & n.a. & n.a. \\
\hline Philippines & 1 & 1 & 68.47 & $\begin{array}{c}62 \\
(n . a .)\end{array}$ & $43.24 \%$ & $\begin{array}{c}0.8409 \\
\quad(1)\end{array}$ & $\begin{array}{c}1.0825 \\
(1)\end{array}$ & -0.1150 & $\begin{array}{c}-1.0442 \\
(1)\end{array}$ \\
\hline Poland & 1 & 0 & n.a. & n.a. & n.a. & n.a. & n.a. & n.a. & n.a. \\
\hline Russia & 3 & 2 & 88.08 & $\begin{array}{l}13 \\
(1)\end{array}$ & $47.25 \%$ & $\begin{array}{l}0.2370 \\
(2)\end{array}$ & $\begin{array}{c}1.6028 \\
(1)\end{array}$ & $\begin{array}{c}0.9030 \\
(2)\end{array}$ & $\begin{array}{c}-1.1883 \\
(1)\end{array}$ \\
\hline S. Africa & 8 & 5 & 19.72 & $\begin{array}{l}178 \\
(75)\end{array}$ & $17.84 \%$ & $\begin{array}{c}0.7814 \\
(5)\end{array}$ & $\begin{array}{c}-0.3712 \\
(2)\end{array}$ & $\begin{array}{c}-0.1064 \\
(3)\end{array}$ & $\begin{array}{c}0.2516 \\
(2)\end{array}$ \\
\hline S. Korea & 6 & 2 & 15.17 & $\begin{array}{c}64 \\
(71)\end{array}$ & $28.78 \%$ & $\begin{array}{c}0.7858 \\
\quad(2)\end{array}$ & $\begin{array}{c}0.9817 \\
(1)\end{array}$ & $\begin{array}{c}-0.2345 \\
(2)\end{array}$ & $\begin{array}{c}-0.7148 \\
(0)\end{array}$ \\
\hline Taiwan & 5 & 0 & n.a. & n.a. & n.a. & n.a. & n.a. & n.a. & n.a. \\
\hline Turkey & 1 & 0 & n.a. & n.a. & n.a. & n.a. & n.a. & n.a. & n.a. \\
\hline Venezuela & 2 & 1 & 68.45 & $\begin{array}{c}16 \\
(\text { n.a. }) \\
\end{array}$ & $55.29 \%$ & $\begin{array}{c}1.1118 \\
(1)\end{array}$ & $\begin{array}{c}0.2958 \\
(1)\end{array}$ & $\begin{array}{c}-1.1376 \\
(1)\end{array}$ & $\begin{array}{c}0.3283 \\
(0)\end{array}$ \\
\hline
\end{tabular}


Table 2b. Pricing tests: No break

This table reports mean OLS estimates for Eq. (2) when it does not experience a statistically significant break (at the $5 \%$ level) for each country in the sample and, in brackets, the number of ADRs for which they are different from zero at the $5 \%$ significance level. Variables and statistics are defined in the notes to Table 1a. $N^{o}$ is the subset of ADRs where date $\widehat{k}_{i}^{m}=\arg \max F_{i}^{m}(k)$, the Wald statistic of Eq. (5), but $F_{i}^{m}\left(\widehat{k}_{i}^{m}\right)<11.78$.

\begin{tabular}{|c|c|c|c|c|c|c|c|c|c|}
\hline & $N$ & $N^{o}$ & $F\left(\widehat{k}_{i}^{m}\right)$ & $\widehat{k}_{i}^{m \pm}$ & $\overline{R_{a}^{2}}$ & $\widehat{b}_{i}^{m}$ & $\widehat{b}_{i}^{U S}$ & $\overline{\Delta \widehat{b}_{i}^{m}}$ & $\overline{\Delta \widehat{b}_{i}^{U S}}$ \\
\hline Total & 156 & 77 & 7.83 & n.a. & $30.84 \%$ & $\begin{array}{c}0.9498 \\
(74)\end{array}$ & $\begin{array}{c}0.2654 \\
(34) \\
\end{array}$ & n.a. & n.a. \\
\hline Argentina & 13 & 4 & 9.10 & n.a. & $8.91 \%$ & $\begin{array}{c}0.5388 \\
(4)\end{array}$ & $\begin{array}{c}0.1182 \\
(1)\end{array}$ & n.a. & n.a. \\
\hline Brazil & 30 & 17 & 6.84 & n.a. & $39.99 \%$ & $\begin{array}{c}0.9734 \\
(17)\end{array}$ & $\begin{array}{c}0.2112 \\
(7)\end{array}$ & n.a. & n.a. \\
\hline Chile & 19 & 8 & 8.64 & n.a. & $35.29 \%$ & $\begin{array}{c}1.1769 \\
(8)\end{array}$ & $\begin{array}{c}0.0890 \\
(0)\end{array}$ & n.a. & n.a. \\
\hline China & 14 & 6 & 9.35 & n.a. & $24.77 \%$ & $\begin{array}{c}0.6409 \\
(4)\end{array}$ & $\begin{array}{c}0.2487 \\
(5)\end{array}$ & n.a. & n.a. \\
\hline Colombia & 1 & 1 & 10.27 & n.a. & $5.93 \%$ & $\begin{array}{c}0.5264 \\
(1)\end{array}$ & $\begin{array}{c}0.3422 \\
(1)\end{array}$ & n.a. & n.a. \\
\hline Hong Kong & 6 & 4 & 8.14 & n.a. & $15.97 \%$ & $\begin{array}{c}1.0619 \\
(4)\end{array}$ & $\begin{array}{c}0.3049 \\
(1)\end{array}$ & n.a. & n.a. \\
\hline Hungary & 1 & 0 & n.a. & n.a. & n.a. & n.a. & n.a. & n.a. & n.a. \\
\hline India & 7 & 5 & 8.95 & n.a. & $30.39 \%$ & $\frac{1.2401}{(5)}$ & $\begin{array}{c}0.5629 \\
\quad(2)\end{array}$ & n.a. & n.a. \\
\hline Indonesia & 2 & 0 & n.a. & n.a. & n.a. & n.a. & n.a. & n.a. & n.a. \\
\hline Israel & 7 & 4 & 6.57 & n.a. & $29.23 \%$ & $\begin{array}{c}1.0782 \\
(4)\end{array}$ & $\begin{array}{c}0.3524 \\
(3)\end{array}$ & n.a. & n.a. \\
\hline Mexico & 27 & 10 & 8.38 & n.a. & $30.79 \%$ & $\begin{array}{c}0.8522 \\
\quad(9)\end{array}$ & $\begin{array}{c}0.2000 \\
(2)\end{array}$ & n.a. & n.a. \\
\hline Peru & 2 & 2 & 7.38 & n.a. & $18.55 \%$ & $\begin{array}{c}1.2486 \\
(2)\end{array}$ & $\begin{array}{c}0.2589 \\
\quad(1)\end{array}$ & n.a. & n.a. \\
\hline Philippines & 1 & 0 & n.a. & n.a. & n.a. & n.a. & n.a. & n.a. & n.a. \\
\hline Poland & 1 & 1 & 5.33 & n.a. & $4.67 \%$ & $\begin{array}{c}1.2698 \\
(1)\end{array}$ & $\begin{array}{c}0.2328 \\
(0)\end{array}$ & n.a. & n.a. \\
\hline Russia & 3 & 1 & 9.99 & n.a. & $38.52 \%$ & $\begin{array}{c}0.8666 \\
(1)\end{array}$ & $\begin{array}{c}0.6097 \\
(1)\end{array}$ & n.a. & n.a. \\
\hline S. Africa & 8 & 3 & 8.29 & n.a. & $14.64 \%$ & $\begin{array}{c}0.7245 \\
(3)\end{array}$ & $\underset{(3)}{-0.3101}$ & n.a. & n.a. \\
\hline S. Korea & 6 & 4 & 7.43 & n.a. & $32.52 \%$ & $\begin{array}{c}0.8847 \\
\quad(4)\end{array}$ & $\begin{array}{c}0.4061 \\
(2)\end{array}$ & n.a. & n.a. \\
\hline Taiwan & 5 & 5 & 5.31 & n.a. & $55.16 \%$ & $\begin{array}{c}1.1398 \\
(5)\end{array}$ & $\begin{array}{c}0.7219 \\
(5)\end{array}$ & n.a. & n.a. \\
\hline Turkey & 1 & 1 & 9.22 & n.a. & $48.74 \%$ & $\begin{array}{c}0.8499 \\
(1)\end{array}$ & $\begin{array}{c}0.2670 \\
(0)\end{array}$ & n.a. & n.a. \\
\hline Venezuela & 2 & 1 & 6.79 & n.a. & $2.53 \%$ & $\begin{array}{c}0.4710 \\
(1)\end{array}$ & $\begin{array}{c}0.4596 \\
(0)\end{array}$ & n.a. & n.a. \\
\hline
\end{tabular}




\section{Table 3. Explaining efficiency breaks}

This table reports maximum likelihood estimates for the Poisson regression model of Eqs. (7) and (8) when $Y_{t}^{m}=E_{t}^{m}$, i.e., explaining the clustering of statistically significant breaks in the efficiency relationship of Eq. (1) for each country $m$ in our sample. The model includes the following seven groups of independent variables (defined in Section 6): Information, trend, economic environment, financial integration, investors' activity, market liquidity, and expected returns. Information: $\sigma_{t}^{m}$ and $\sigma_{t}^{U S}$ are domestic and U.S. market return volatility computed as the standard deviation of weekly returns for the corresponding index in local currency (from Datastream) over the interval $[t-99, t]$. Trend: $d_{t}^{m+}$ and $d_{t}^{m-}$ (and $d_{t}^{U S+}$ and $d_{t}^{U S-}$ ) are dummies equal to one if the sign of $R_{M t}^{m}\left(r_{M t}^{U S}\right)$ over the current and each of the previous two weeks is positive or negative, respectively, and equal to zero otherwise. Economic environment: $\sigma_{m t}^{F X}$ is the standard deviation of weekly returns for the exchange rate between the domestic currency for country $m$ and the dollar (from Datastream) over the interval $[t-99, t]$; $d_{m t}^{F X+}$ and $d_{m t}^{F X-}$ are dummies equal to one if the local currency has been depreciating or appreciating versus the dollar for at least three consecutive weeks, respectively, and zero otherwise; $T_{t}^{m}$ is the monthly ratio of exports plus imports divided by GDP for country $m$ (from IFS) in the corresponding week $t$; $C_{t}^{m}$ is the monthly numeric Standard \& Poors' foreign currency sovereign credit rating (from a high of 26 for AAA to a low of 1 for Default) for country $m$ in the corresponding week $t$. Financial integration: $I_{t}^{m}$ is a dummy equal to one if $t$ is greater than (or equal to) the lower bound of the confidence interval for the estimated integration date in Bekaert et al. (2002). Investors' activity: $F_{t}^{m}$ is the net monthly equity capital flows (in millions of dollars) for country $m$ (from the U.S. Treasury Bulletin) in the corresponding week $t$. Market liquidity: $L_{t}^{U S}$ and $L_{t}^{m}$ are the ratios of weekly volume of trading to weekly market capitalization, both in local currency, for the U.S. and each country $m$, respectively (from Datastream). Expected returns: $D_{t}^{m}$ and $D_{t}^{U S}$ are weekly time series of dividend yields (from Datastream) in each country $m$ 's stock market and in the U.S. stock market, respectively. For each country $m$, the sample over which the model is estimated starts on the first potential break date for the ADR with the earliest return data available $\left(t_{0}\right)$; hence, $N$ is the number of observations used for each country's estimation. For each of the estimated coefficients we report the corresponding $t$-statistic in parentheses. We also report two $R^{2}$ statistics which measure the improvement of the fit resulting from using $\lambda_{t}^{m}$ instead of $\overline{E_{t}^{m}}$, the mean of $E_{t}^{m}$ over the sample, to predict $Y_{t}^{m}$. The first one, the Pearson $R_{P}^{2}$, is computed as $1-\overline{E_{t}^{m}}\left[\sum_{t=1}^{N}\left(E_{t}^{m}-\lambda_{t}^{m}\right)^{2}\right] /\left[\sum_{t=1}^{N}\left(E_{t}^{m}-\overline{E_{t}^{m}}\right)^{2}\right] ;$ the second one, the Deviance $R_{P}^{2}$, is computed as $1-\overline{E_{t}^{m}}\left[\sum_{t=1}^{N} E_{t}^{m} \ln \left(E_{t}^{m} / \lambda_{t}^{m}\right)\right] /\left[\sum_{t=1}^{N} E_{t}^{m} \ln \left(E_{t}^{m} / \overline{E_{t}^{m}}\right)\right]$. The goodness-of-fit statistic $\chi^{2}$ tests the hypothesis that all estimated coefficients in Eq. (8) are zero. The $p$-values for this test (rounded to 4 decimals) are in parentheses. A "*”, "**”, or “***” indicate significance at the $10 \%, 5 \%$, or $1 \%$ level, respectively. 
Table 3 (Continued).

\begin{tabular}{|c|c|c|c|c|c|c|c|c|}
\hline & Argentina & Brazil & Chile & China & Hong Kong & India & Indonesia & Israel \\
\hline \multicolumn{9}{|c|}{ Information } \\
\hline$\sigma_{t}^{m}$ & $\begin{array}{c}-102.5^{* * *} \\
(-5.49)\end{array}$ & $\begin{array}{c}-0.2720 \\
(-0.11)\end{array}$ & $\begin{array}{c}-20.65^{* * *} \\
(-4.69)\end{array}$ & $\begin{array}{c}11.30^{* * *} \\
(5.22)\end{array}$ & $\begin{array}{c}-124.7^{* *} \\
(-2.15)\end{array}$ & $\begin{array}{c}87.91^{* * *} \\
(5.55)\end{array}$ & $\begin{array}{c}-28.02^{* * *} \\
(-4.08)\end{array}$ & $\begin{array}{c}-22.23^{*} \\
(-1.76)\end{array}$ \\
\hline$\sigma_{t}^{U S}$ & $\begin{array}{c}138.7^{* * *} \\
(8.26)\end{array}$ & $\begin{array}{c}40.21^{* * *} \\
(5.78)\end{array}$ & $\begin{array}{c}56.54^{* * *} \\
(8.55)\end{array}$ & $\begin{array}{c}17.65^{*} \\
(1.92)\end{array}$ & $\begin{array}{l}29.02 \\
(0.51)\end{array}$ & $\begin{array}{c}-258.5^{* * *} \\
(-3.51)\end{array}$ & $\begin{array}{c}85.44^{* * *} \\
(6.18)\end{array}$ & $\begin{array}{c}36.28^{* * *} \\
(3.14)\end{array}$ \\
\hline \multicolumn{9}{|l|}{ Trend } \\
\hline$d_{t}^{m+}$ & $\begin{array}{c}0.0581 \\
(0.42)\end{array}$ & $\begin{array}{c}-0.0497 \\
(-0.86)\end{array}$ & $\begin{array}{c}0.0115 \\
(0.22)\end{array}$ & $\begin{array}{c}-0.0638 \\
(-0.98)\end{array}$ & $\begin{array}{c}-0.3400 \\
(-0.84)\end{array}$ & $\begin{array}{c}0.4674^{*} \\
(1.69)\end{array}$ & $\begin{array}{l}0.0666 \\
(-0.49)\end{array}$ & $\begin{array}{c}-0.0797 \\
(-0.87)\end{array}$ \\
\hline$d_{t}^{m-}$ & $\begin{array}{c}0.2523^{*} \\
(1.85)\end{array}$ & $\begin{array}{c}0.0280 \\
(0.38)\end{array}$ & $\begin{array}{c}0.0319 \\
(0.59)\end{array}$ & $\begin{array}{c}-0.0287 \\
(-0.45)\end{array}$ & $\begin{array}{c}-0.0330 \\
(-0.10)\end{array}$ & $\begin{array}{c}-0.6019^{* *} \\
(-2.44)\end{array}$ & $\begin{array}{c}0.0254 \\
(0.19)\end{array}$ & $\begin{array}{c}0.0440 \\
(0.40)\end{array}$ \\
\hline$d_{t}^{U S+}$ & $\begin{array}{c}-0.0714 \\
(-0.45)\end{array}$ & $\begin{array}{c}-0.0112 \\
(-0.20)\end{array}$ & $\begin{array}{c}-0.0193 \\
(-0.38)\end{array}$ & $\begin{array}{c}0.0066 \\
(0.11)\end{array}$ & $\begin{array}{c}-0.2809 \\
(-0.71)\end{array}$ & $\begin{array}{c}0.0938 \\
(0.33)\end{array}$ & $\begin{array}{c}-0.0830 \\
(-0.64)\end{array}$ & $\begin{array}{c}0.0167 \\
(0.18)\end{array}$ \\
\hline$d_{t}^{U S-}$ & $\begin{array}{c}0.1240 \\
(1.03)\end{array}$ & $\begin{array}{c}-0.0003 \\
(-0.01)\end{array}$ & $\begin{array}{c}0.0192 \\
(0.30)\end{array}$ & $\begin{array}{c}-0.0210 \\
(-0.30)\end{array}$ & $\begin{array}{c}-0.0487 \\
(-0.14)\end{array}$ & $\begin{array}{c}0.3998^{*} \\
(1.80)\end{array}$ & $\begin{array}{c}0.0943 \\
(0.65)\end{array}$ & $\begin{array}{c}-0.0475 \\
(-0.41)\end{array}$ \\
\hline \multicolumn{9}{|c|}{ Economic environment } \\
\hline$\sigma_{m t}^{F X}$ & $\begin{array}{c}84.69^{* * *} \\
(6.33)\end{array}$ & $\begin{array}{c}2.5500^{*} \\
(1.65)\end{array}$ & $\begin{array}{c}-2.8185 \\
(-0.41)\end{array}$ & $\begin{array}{c}-626.0^{* * *} \\
(-4.69)\end{array}$ & $\begin{array}{c}-16,436^{* * *} \\
(-3.86)\end{array}$ & $\begin{array}{c}-1,107.8^{* * *} \\
(-3.79)\end{array}$ & $\begin{array}{c}-1.4116 \\
(-0.04)\end{array}$ & $\begin{array}{c}-91.04^{* * *} \\
(-4.29)\end{array}$ \\
\hline$d_{m t}^{F X+}$ & $\begin{array}{c}-0.1407 \\
(-0.83)\end{array}$ & $\begin{array}{c}-0.0446 \\
(-0.92)\end{array}$ & $\begin{array}{c}0.0227 \\
(0.49)\end{array}$ & $\begin{array}{c}-0.1044 \\
(-1.27)\end{array}$ & $\begin{array}{c}-0.1631 \\
(-0.41)\end{array}$ & $\begin{array}{c}0.5823^{* *} \\
(2.18)\end{array}$ & $\begin{array}{c}-0.0494 \\
(-0.39)\end{array}$ & $\begin{array}{c}-0.0362 \\
(-0.36)\end{array}$ \\
\hline$d_{m t}^{F X-}$ & $\begin{array}{c}0.0172 \\
(0.13)\end{array}$ & $\begin{array}{c}0.0189 \\
(0.26)\end{array}$ & $\begin{array}{c}0.0161 \\
(0.26)\end{array}$ & $\begin{array}{c}0.0531 \\
(0.57)\end{array}$ & $\begin{array}{c}0.0208 \\
(0.05)\end{array}$ & $\begin{array}{c}-0.1677 \\
(-0.70)\end{array}$ & $\begin{array}{c}-0.0097 \\
(-0.06)\end{array}$ & $\begin{array}{c}0.0178 \\
(0.17)\end{array}$ \\
\hline$T_{t}^{m}$ & $\begin{array}{c}-6.7281^{* *} \\
(-2.23)\end{array}$ & $\begin{array}{l}4.9429^{* * *} \\
\quad(4.28)\end{array}$ & $\begin{array}{c}-6.3495^{* * *} \\
(-6.57)\end{array}$ & n.a. & $\begin{array}{c}-6.3460^{* * *} \\
(-2.82)\end{array}$ & $\begin{array}{c}-42.74^{*} \\
(-1.73)\end{array}$ & $\begin{array}{c}2.8350^{* * *} \\
(6.64)\end{array}$ & $\begin{array}{c}0.4647 \\
(0.49)\end{array}$ \\
\hline$C_{t}^{m}$ & $\begin{array}{c}-0.1140^{* * *} \\
(-5.17)\end{array}$ & $\begin{array}{c}0.0637^{* * *} \\
(3.94)\end{array}$ & $\begin{array}{c}0.2884^{* * *} \\
(10.99)\end{array}$ & $\begin{array}{c}0.0796^{* * *} \\
(4.20)\end{array}$ & $\begin{array}{c}1.2077^{* * *} \\
(3.40)\end{array}$ & $\begin{array}{c}0.7867 \\
(1.51)\end{array}$ & $\begin{array}{c}-0.0061 \\
(-0.43)\end{array}$ & $\begin{array}{c}0.0536 \\
(1.42)\end{array}$ \\
\hline \multicolumn{9}{|c|}{ Financial integration } \\
\hline \multicolumn{9}{|c|}{ Investors' activity } \\
\hline$F_{t}^{m}$ & $\begin{array}{c}-0.0006 \\
(-1.64)\end{array}$ & $\begin{array}{c}-0.0001 \\
(-1.15)\end{array}$ & $\begin{array}{c}-0.0001 \\
(-0.43)\end{array}$ & $\begin{array}{c}0.0002 \\
(0.85)\end{array}$ & $\begin{array}{c}-0.00004 \\
(-0.40)\end{array}$ & $\begin{array}{c}-0.0032^{*} \\
(-1.66)\end{array}$ & $\begin{array}{c}-0.0005 \\
(-0.49)\end{array}$ & $\begin{array}{c}-0.0001 \\
(-0.37)\end{array}$ \\
\hline \multicolumn{9}{|c|}{ Market liquidity } \\
\hline$L_{t}^{m}$ & $\begin{array}{c}-0.1180^{* *} \\
(-2.09)\end{array}$ & $\begin{array}{c}0.0072 \\
(0.25)\end{array}$ & $\begin{array}{c}0.0879 \\
(0.07)\end{array}$ & $\begin{array}{c}-0.0009^{* * *} \\
(-2.78)\end{array}$ & $\begin{array}{c}-0.1580 \\
(-0.42)\end{array}$ & $\begin{array}{c}-30.55^{* * *} \\
(-4.30)\end{array}$ & $\begin{array}{l}11.83 \\
(0.94)\end{array}$ & n.a. \\
\hline$L_{t}^{U S}$ & $\begin{array}{c}0.1255 \\
(0.71)\end{array}$ & $\begin{array}{l}0.2249^{* *} \\
(2.07)\end{array}$ & $\begin{array}{l}0.2747^{* *} \\
(2.54)\end{array}$ & $\begin{array}{c}0.2505^{* *} \\
(1.99)\end{array}$ & $\begin{array}{c}0.3525 \\
(0.65)\end{array}$ & $\begin{array}{c}0.3368 \\
(0.93)\end{array}$ & $\begin{array}{c}0.4947^{*} \\
(1.77)\end{array}$ & $\begin{array}{c}0.0311 \\
(0.16)\end{array}$ \\
\hline \multicolumn{9}{|c|}{ Expected returns } \\
\hline$D_{t}^{m}$ & $\begin{array}{c}0.3828^{* * *} \\
(9.02)\end{array}$ & $\begin{array}{c}-0.0693^{* * *} \\
(-4.24)\end{array}$ & $\begin{array}{c}-0.1251^{* * *} \\
(-3.76)\end{array}$ & $\begin{array}{c}-0.1627^{* *} \\
(-5.89)\end{array}$ & $\begin{array}{c}0.9551^{* *} \\
(1.97)\end{array}$ & $\begin{array}{c}0.4890 \\
(1.20)\end{array}$ & $\begin{array}{c}0.1771^{*} \\
(1.68)\end{array}$ & n.a. \\
\hline$D_{t}^{U S}$ & $\begin{array}{c}0.1043 \\
(0.31) \\
\end{array}$ & $\begin{array}{c}-0.7208^{* * *} \\
(-8.10)\end{array}$ & $\begin{array}{c}-0.4806^{* * *} \\
(-7.43) \\
\end{array}$ & $\begin{array}{c}0.1752 \\
(0.80) \\
\end{array}$ & $\begin{array}{c}-3.9257^{* *} \\
(-2.53) \\
\end{array}$ & $\begin{array}{c}4.6872^{* * *} \\
(4.03) \\
\end{array}$ & $\begin{array}{c}-2.5391^{* * *} \\
(-6.94)\end{array}$ & $\begin{array}{c}-0.0879 \\
(-0.74) \\
\end{array}$ \\
\hline$t_{0}$ & $12 / 7 / 93$ & $3 / 15 / 94$ & $11 / 28 / 89$ & $12 / 21 / 93$ & $11 / 19 / 96$ & $7 / 14 / 98$ & $3 / 21 / 95$ & $6 / 1 / 93$ \\
\hline$N$ & 487 & 473 & 697 & 485 & 333 & 247 & 420 & 566 \\
\hline$R_{P}^{2}$ & $95.86 \%$ & $94.55 \%$ & $95.95 \%$ & $88.53 \%$ & $90.71 \%$ & $77.73 \%$ & $81.98 \%$ & $74.52 \%$ \\
\hline$R_{D}^{2}$ & $94.45 \%$ & $92.81 \%$ & $96.09 \%$ & $91.41 \%$ & $88.79 \%$ & $78.91 \%$ & $85.67 \%$ & $80.47 \%$ \\
\hline$\chi^{2}$ & $\begin{array}{c}132.5^{* * *} \\
(0.0000) \\
\end{array}$ & $\begin{array}{c}74.87^{* * *} \\
(0.0000) \\
\end{array}$ & $\begin{array}{c}68.79^{* * *} \\
(0.0000) \\
\end{array}$ & $\begin{array}{c}146.9^{* * *} \\
(0.0000) \\
\end{array}$ & $\begin{array}{c}21.65 \\
(0.1172) \\
\end{array}$ & $\begin{array}{c}67.17^{* * *} \\
(0.0000) \\
\end{array}$ & $\begin{array}{c}53.40^{* * *} \\
(0.0000) \\
\end{array}$ & $\begin{array}{c}50.37^{* * *} \\
(0.0000) \\
\end{array}$ \\
\hline
\end{tabular}


Table 3 (Continued).

\begin{tabular}{|c|c|c|c|c|c|c|c|c|}
\hline & Mexico & Peru & Philippines & Poland & Russia & S. Africa & S. Korea & Venezuela \\
\hline \multicolumn{9}{|c|}{ Information } \\
\hline$\sigma_{t}^{m}$ & $\begin{array}{c}-6.8658^{*} \\
(-1.93)\end{array}$ & $\begin{array}{l}24.49 \\
(0.88)\end{array}$ & $\begin{array}{c}-1.2412 \\
(-0.08)\end{array}$ & $\begin{array}{c}8.6179 \\
(0.05)\end{array}$ & $\begin{array}{c}-24.24^{* *} \\
(-3.36)\end{array}$ & $\begin{array}{c}-17.24^{* * *} \\
(-5.09)\end{array}$ & $\begin{array}{c}-37.75^{* * *} \\
(-3.99)\end{array}$ & $\begin{array}{c}-111.0^{* * *} \\
(-4.52)\end{array}$ \\
\hline$\sigma_{t}^{U S}$ & $\begin{array}{c}47.32^{* * *} \\
(9.39)\end{array}$ & $\begin{array}{c}128.9^{* * *} \\
(3.81)\end{array}$ & $\begin{array}{l}-22.73 \\
(-1.01)\end{array}$ & $\begin{array}{l}14.36 \\
(0.16)\end{array}$ & $\begin{array}{c}83.31^{* * *} \\
(3.89)\end{array}$ & $\begin{array}{c}17.49^{* * *} \\
(4.48)\end{array}$ & $\begin{array}{c}97.61^{* * *} \\
(8.20)\end{array}$ & $\begin{array}{c}212.8^{* * *} \\
(4.03)\end{array}$ \\
\hline \multicolumn{9}{|l|}{ Trend } \\
\hline$d_{t}^{m+}$ & $\begin{array}{c}0.0294 \\
(0.61)\end{array}$ & $\begin{array}{c}-0.0605 \\
(-0.28)\end{array}$ & $\begin{array}{c}-0.2039 \\
(-1.21)\end{array}$ & $\begin{array}{c}0.0741 \\
(0.17)\end{array}$ & $\begin{array}{c}0.0251 \\
(0.22)\end{array}$ & $\begin{array}{c}0.0274 \\
(0.54)\end{array}$ & $\begin{array}{c}-0.0229 \\
(-0.21)\end{array}$ & $\begin{array}{c}-0.1753 \\
(-0.49)\end{array}$ \\
\hline$d_{t}^{m-}$ & $\begin{array}{c}0.0678 \\
(1.19)\end{array}$ & $\begin{array}{c}-0.1066 \\
(-0.58)\end{array}$ & $\begin{array}{c}-0.0046 \\
(-0.04)\end{array}$ & $\begin{array}{c}-0.0461 \\
(-0.13)\end{array}$ & $\begin{array}{c}-0.0644 \\
(-0.47)\end{array}$ & $\begin{array}{c}-0.0032 \\
(-0.05)\end{array}$ & $\begin{array}{c}0.0438 \\
(0.37)\end{array}$ & $\begin{array}{c}-0.0830 \\
(-0.35)\end{array}$ \\
\hline$d_{t}^{U S+}$ & $\begin{array}{c}-0.0296 \\
(-0.65)\end{array}$ & $\begin{array}{c}-0.0536 \\
(-0.28)\end{array}$ & $\begin{array}{c}0.0808 \\
(0.61)\end{array}$ & $\begin{array}{r}-0.2597 \\
(-0.39)\end{array}$ & $\begin{array}{c}-0.0862 \\
(-0.67)\end{array}$ & $\begin{array}{c}-0.0169 \\
(-0.32)\end{array}$ & $\begin{array}{c}-0.0816 \\
(-0.80)\end{array}$ & $\begin{array}{c}-0.0736 \\
(-0.22)\end{array}$ \\
\hline$d_{t}^{U S-}$ & $\begin{array}{c}0.0276 \\
(0.51)\end{array}$ & $\begin{array}{c}0.0746 \\
(0.36)\end{array}$ & $\begin{array}{c}-0.0540 \\
(-0.30)\end{array}$ & $\begin{array}{c}0.0297 \\
(0.08)\end{array}$ & $\begin{array}{c}0.1320 \\
(0.99)\end{array}$ & $\begin{array}{c}0.0371 \\
(0.55)\end{array}$ & $\begin{array}{c}0.0804 \\
(0.75)\end{array}$ & $\begin{array}{c}0.3198 \\
(1.28)\end{array}$ \\
\hline \multicolumn{9}{|c|}{ Economic environment } \\
\hline$\sigma_{m t}^{F X}$ & $\begin{array}{c}10.47^{* * *} \\
(3.73)\end{array}$ & $\begin{array}{c}0.9523 \\
(0.02)\end{array}$ & $\begin{array}{c}-4.0247 \\
(-0.29)\end{array}$ & $\begin{array}{l}-139.8 \\
(-0.29)\end{array}$ & $\begin{array}{c}9.5619^{* * *} \\
(4.15)\end{array}$ & $\begin{array}{l}8.2074^{* * *} \\
(3.25)\end{array}$ & $\begin{array}{c}39.23^{* * *} \\
(5.24)\end{array}$ & $\begin{array}{c}-9.9911 \\
(-0.47)\end{array}$ \\
\hline$d_{m t}^{F X+}$ & $\begin{array}{c}0.0439 \\
(0.89)\end{array}$ & $\begin{array}{c}0.1129 \\
(0.54)\end{array}$ & $\begin{array}{c}-0.0962 \\
(-0.71)\end{array}$ & $\begin{array}{c}0.0156 \\
(0.03)\end{array}$ & $\begin{array}{c}-0.1681 \\
(-1.60)\end{array}$ & $\begin{array}{c}-0.0231 \\
(-0.44)\end{array}$ & $\begin{array}{c}0.1510 \\
(1.45)\end{array}$ & $\begin{array}{c}0.0556 \\
(0.26)\end{array}$ \\
\hline$d_{m t}^{F X-}$ & $\begin{array}{c}0.0108 \\
(0.20)\end{array}$ & $\begin{array}{c}-0.0296 \\
(-0.12)\end{array}$ & $\begin{array}{c}0.0509 \\
(0.25)\end{array}$ & $\begin{array}{c}-0.0496 \\
(-0.12)\end{array}$ & $\begin{array}{c}-0.2572^{*} \\
(-1.72)\end{array}$ & $\begin{array}{c}0.0306 \\
(0.51)\end{array}$ & $\begin{array}{c}0.0643 \\
(0.64)\end{array}$ & $\begin{array}{c}-0.1265 \\
(-0.36)\end{array}$ \\
\hline$T_{t}^{m}$ & $\begin{array}{c}-0.1151 \\
(-0.30)\end{array}$ & $\begin{array}{l}-12.15 \\
(-0.95)\end{array}$ & $\begin{array}{l}3.3023^{* * *} \\
(2.78)\end{array}$ & $\begin{array}{c}15,872 \\
(0.00)\end{array}$ & $\begin{array}{c}1.4961 \\
(1.09)\end{array}$ & $\begin{array}{c}-1.1511^{* *} \\
(-2.29)\end{array}$ & $\begin{array}{c}2.3423^{* * *} \\
(3.26)\end{array}$ & $\begin{array}{c}-1.8429 \\
(-0.24)\end{array}$ \\
\hline$C_{t}^{m}$ & $\begin{array}{c}0.1432^{* * *} \\
(6.27)\end{array}$ & $\begin{array}{c}0.0248 \\
(0.08)\end{array}$ & $\begin{array}{c}-0.4543^{* * *} \\
(-3.16)\end{array}$ & $\begin{array}{c}-529.6 \\
(0.00)\end{array}$ & $\begin{array}{c}0.0509^{* *} \\
(2.23)\end{array}$ & $\begin{array}{c}0.0777^{* * *} \\
(5.43)\end{array}$ & $\begin{array}{c}-0.0012 \\
(-0.04)\end{array}$ & $\begin{array}{c}-0.0050 \\
(-0.03)\end{array}$ \\
\hline \multicolumn{9}{|c|}{ Financial integration } \\
\hline$I_{t}^{m}$ & n.a. & n.a. & $\begin{array}{c}5.2367^{* * *} \\
(2.64)\end{array}$ & n.a. & n.a. & n.a. & n.a. & n.a. \\
\hline \multicolumn{9}{|c|}{ Investors' activity } \\
\hline$F_{t}^{m}$ & $\begin{array}{c}-0.00001 \\
(-0.22)\end{array}$ & $\begin{array}{c}-0.0011 \\
(-0.81)\end{array}$ & $\begin{array}{c}0.0009 \\
(0.52)\end{array}$ & $\begin{array}{c}0.0036 \\
(0.21)\end{array}$ & $\begin{array}{c}0.0014 \\
(1.11)\end{array}$ & $\begin{array}{c}0.0001 \\
(0.39)\end{array}$ & $\begin{array}{c}-0.0002 \\
(-1.42)\end{array}$ & $\begin{array}{c}0.0012 \\
(0.52)\end{array}$ \\
\hline \multicolumn{9}{|c|}{ Market liquidity } \\
\hline$L_{t}^{m}$ & $\begin{array}{c}-0.0846 \\
(-1.58)\end{array}$ & $\begin{array}{c}0.0640 \\
(0.72)\end{array}$ & $\begin{array}{c}-0.1679 \\
(-1.04)\end{array}$ & $\begin{array}{c}0.4861 \\
(0.21)\end{array}$ & $\begin{array}{c}0.0002 \\
(0.29)\end{array}$ & $\begin{array}{c}0.3019 \\
(1.46)\end{array}$ & $\begin{array}{c}1.5076 \\
(0.11)\end{array}$ & $\begin{array}{c}-0.5078 \\
(-0.08)\end{array}$ \\
\hline$L_{t}^{U S}$ & $\begin{array}{c}0.4541^{* *} \\
(5.71)\end{array}$ & $\begin{array}{c}0.5859 \\
(1.51)\end{array}$ & $\begin{array}{c}0.4847 \\
(1.53)\end{array}$ & $\begin{array}{c}0.2167 \\
(0.34)\end{array}$ & $\begin{array}{c}0.5227^{* *} \\
(2.31)\end{array}$ & $\begin{array}{c}0.5182^{* *} \\
(4.23)\end{array}$ & $\begin{array}{c}0.5955^{* *} \\
(3.01)\end{array}$ & $\begin{array}{c}0.5628 \\
(1.44)\end{array}$ \\
\hline \multicolumn{9}{|c|}{ Expected returns } \\
\hline$D_{t}^{m}$ & $\begin{array}{c}-0.1228^{* *} \\
(-2.14)\end{array}$ & $\begin{array}{c}0.5316 \\
(1.53)\end{array}$ & $\begin{array}{c}0.2729 \\
(1.28)\end{array}$ & $\begin{array}{c}-0.5609 \\
(-0.33)\end{array}$ & $\begin{array}{c}-0.0662 \\
(-0.95)\end{array}$ & $0.1112^{* * *}$ & $\begin{array}{c}0.0621 \\
(0.77)\end{array}$ & $\begin{array}{c}-0.0421 \\
(-0.43)\end{array}$ \\
\hline$D_{t}^{U S}$ & $\begin{array}{c}-0.8269^{* * *} \\
(-9.21)\end{array}$ & $\begin{array}{c}-1.6017^{* * *} \\
(-3.11)\end{array}$ & $\begin{array}{c}-0.9743^{* * *} \\
(-3.45)\end{array}$ & $\begin{array}{c}0.0750 \\
(0.03)\end{array}$ & $\begin{array}{c}-1.5684^{* * *} \\
(-5.24)\end{array}$ & $\begin{array}{c}-0.1552^{* * *} \\
(-4.30)\end{array}$ & $\begin{array}{c}-1.9696^{* * *} \\
(-5.14)\end{array}$ & $\begin{array}{c}-1.4139 \\
(-1.24) \\
\end{array}$ \\
\hline$t_{0}$ & $5 / 31 / 88$ & $10 / 15 / 96$ & $2 / 9 / 88$ & $12 / 5 / 00$ & $6 / 3 / 97$ & $5 / 27 / 80$ & $3 / 14 / 95$ & $8 / 17 / 93$ \\
\hline$N$ & 775 & 338 & 791 & 122 & 305 & 1,210 & 421 & 503 \\
\hline$R_{P}^{2}$ & $97.68 \%$ & $59.76 \%$ & $78.67 \%$ & $98.48 \%$ & $63.08 \%$ & $88.01 \%$ & $75.10 \%$ & $93.04 \%$ \\
\hline$R_{D}^{2}$ & $97.39 \%$ & $71.13 \%$ & $81.35 \%$ & $98.35 \%$ & $70.78 \%$ & $85.21 \%$ & $82.93 \%$ & $90.32 \%$ \\
\hline$\chi^{2}$ & $\begin{array}{c}102.8^{* * *} \\
(0.0000)\end{array}$ & $\begin{array}{c}39.04^{* * *} \\
(0.0006)\end{array}$ & $\begin{array}{c}78.50^{* * *} \\
(0.0000)\end{array}$ & $\begin{array}{c}0.8687 \\
(1.0000)\end{array}$ & $\begin{array}{c}71.90^{* * *} \\
(0.0000)\end{array}$ & $\begin{array}{c}92.67^{* * *} \\
(0.0000)\end{array}$ & $\begin{array}{c}104.4^{* * *} \\
(0.0000)\end{array}$ & $\begin{array}{c}38.57^{* * *} \\
(0.0007)\end{array}$ \\
\hline
\end{tabular}




\section{Table 4. Explaining pricing breaks}

This table reports maximum likelihood estimates for the Poisson regression model of Eqs. (7) and (8) when $Y_{t}^{m}=P_{t}^{m}$, i.e., explaining the clustering of statistically significant breaks in the pricing relationship of Eq. (2) for each country $m$ in our sample. The model includes the following seven groups of independent variables (defined in Section 6): Information, trend, economic environment, financial integration, investors' activity, market liquidity, and expected returns. Information: $\sigma_{t}^{m}$ and $\sigma_{t}^{U S}$ are domestic and U.S. market return volatility computed as the standard deviation of weekly returns for the corresponding index in local currency (from Datastream) over the interval $[t-99, t]$. Trend: $d_{t}^{m+}$ and $d_{t}^{m-}$ (and $d_{t}^{U S+}$ and $d_{t}^{U S-}$ ) are dummies equal to one if the sign of $R_{M t}^{m}\left(r_{M t}^{U S}\right)$ over the current and each of the previous two weeks is positive or negative, respectively, and equal to zero otherwise. Economic environment: $\sigma_{m t}^{F X}$ is the standard deviation of weekly returns for the exchange rate between the domestic currency for country $m$ and the dollar (from Datastream) over the interval $[t-99, t]$; $d_{m t}^{F X+}$ and $d_{m t}^{F X-}$ are dummies equal to one if the local currency has been depreciating or appreciating versus the dollar for at least three consecutive weeks, respectively, and zero otherwise; $T_{t}^{m}$ is the monthly ratio of exports plus imports divided by GDP for country $m$ (from IFS) in the corresponding week $t$; $C_{t}^{m}$ is the monthly numeric Standard \& Poors' foreign currency sovereign credit rating (from a high of 26 for AAA to a low of 1 for Default) for country $m$ in the corresponding week $t$. Financial integration: $I_{t}^{m}$ is a dummy equal to one if $t$ is greater than (or equal to) the lower bound of the confidence interval for the estimated integration date in Bekaert et al. (2002). Investors' activity: $F_{t}^{m}$ is the net monthly equity capital flows (in millions of dollars) for country $m$ (from the U.S. Treasury Bulletin) in the corresponding week $t$. Market liquidity: $L_{t}^{U S}$ and $L_{t}^{m}$ are the ratios of weekly volume of trading to weekly market capitalization, both in local currency, for the U.S. and each country $m$, respectively (from Datastream). Expected returns: $D_{t}^{m}$ and $D_{t}^{U S}$ are weekly time series of dividend yields (from Datastream) in each country m's stock market and in the U.S. stock market, respectively. For each country $m$, the sample over which the model is estimated starts on the first potential break date for the ADR with the earliest return data available $\left(t_{0}\right)$; hence, $N$ is the number of observations used for each country's estimation. For each of the estimated coefficients we report the corresponding $t$-statistic in parentheses. We also report two $R^{2}$ statistics which measure the improvement of the fit resulting from using $\lambda_{t}^{m}$ instead of $\overline{P_{t}^{m}}$, the mean of $P_{t}^{m}$ over the sample, to predict $Y_{t}^{m}$. The first one, the Pearson $R_{P}^{2}$, is computed as $1-\overline{P_{t}^{m}}\left[\sum_{t=1}^{N}\left(P_{t}^{m}-\lambda_{t}^{m}\right)^{2}\right] /\left[\sum_{t=1}^{N}\left(P_{t}^{m}-\overline{P_{t}^{m}}\right)^{2}\right]$; the second one, the Deviance $R_{P}^{2}$, is computed as $1-\overline{P_{t}^{m}}\left[\sum_{t=1}^{N} P_{t}^{m} \ln \left(P_{t}^{m} / \lambda_{t}^{m}\right)\right] /\left[\sum_{t=1}^{N} P_{t}^{m} \ln \left(P_{t}^{m} / \overline{P_{t}^{m}}\right)\right]$. The goodness-of-fit statistic $\chi^{2}$ tests the hypothesis that all estimated coefficients in Eq. (8) are zero. The $p$-values for this test (rounded to 4 decimals) are in parentheses. A "*”, "**”, or “***” indicate significance at the $10 \%, 5 \%$, or $1 \%$ level, respectively. 
Table 4 (Continued).

\begin{tabular}{|c|c|c|c|c|c|c|c|c|}
\hline & Argentina & Brazil & Chile & China & Hong Kong & Hungary & India & Indonesia \\
\hline \multicolumn{9}{|c|}{ Information } \\
\hline$\sigma_{t}^{m}$ & $\begin{array}{c}-63.03^{* * *} \\
(-4.79)\end{array}$ & $\begin{array}{c}-24.58^{* * *} \\
(-5.72)\end{array}$ & $\begin{array}{c}-7.6265 \\
(-1.61)\end{array}$ & $\begin{array}{c}-2.4965 \\
(-1.14)\end{array}$ & $\begin{array}{c}-2.7346 \\
(-0.25)\end{array}$ & $\begin{array}{l}10.35 \\
(0.56)\end{array}$ & $\begin{array}{c}30.67^{* *} \\
(2.56)\end{array}$ & $\begin{array}{c}-27.20^{* * *} \\
(-4.02)\end{array}$ \\
\hline$\sigma_{t}^{U S}$ & $\begin{array}{c}196.2^{* * *} \\
(12.63)\end{array}$ & $\begin{array}{c}114.0^{* * *} \\
(13.36)\end{array}$ & $\begin{array}{c}75.96^{* * *} \\
(10.90)\end{array}$ & $\begin{array}{c}50.70^{* * *} \\
(8.05)\end{array}$ & $\begin{array}{c}51.25^{*} \\
(1.95)\end{array}$ & $\begin{array}{c}117.6^{* * *} \\
(2.97)\end{array}$ & $\begin{array}{c}72.11^{*} \\
(1.81)\end{array}$ & $\begin{array}{c}78.57^{* * *} \\
(5.81)\end{array}$ \\
\hline \multicolumn{9}{|l|}{ Trend } \\
\hline$d_{t}^{m+}$ & $\begin{array}{c}0.0601 \\
(0.48)\end{array}$ & $\begin{array}{c}0.0700 \\
(1.14)\end{array}$ & $\begin{array}{c}0.0121 \\
(0.22)\end{array}$ & $\begin{array}{c}-0.0913 \\
(-1.31)\end{array}$ & $\begin{array}{c}-0.1270 \\
(-0.88)\end{array}$ & $\begin{array}{c}0.1449 \\
(0.66)\end{array}$ & $\begin{array}{c}0.0363 \\
(0.21)\end{array}$ & $\begin{array}{c}-0.0523 \\
(-0.39)\end{array}$ \\
\hline$d_{t}^{m-}$ & $\begin{array}{c}0.1821^{*} \\
(1.75)\end{array}$ & $\begin{array}{c}0.1122 \\
(1.52)\end{array}$ & $\begin{array}{c}0.0479 \\
(0.84)\end{array}$ & $\begin{array}{c}-0.0030 \\
(-0.04)\end{array}$ & $\begin{array}{c}-0.0153 \\
(-0.12)\end{array}$ & $\begin{array}{c}0.0367 \\
(0.19)\end{array}$ & $\begin{array}{c}-0.1596 \\
(-0.94)\end{array}$ & $\begin{array}{c}0.0023 \\
(0.02)\end{array}$ \\
\hline$d_{t}^{U S+}$ & $\begin{array}{c}-0.1369 \\
(-1.08)\end{array}$ & $\begin{array}{c}-0.0941 \\
(-1.51)\end{array}$ & $\begin{array}{c}-0.0328 \\
(-0.60)\end{array}$ & $\begin{array}{c}-0.0074 \\
(-0.12)\end{array}$ & $\begin{array}{c}0.0047 \\
(0.04)\end{array}$ & $\begin{array}{c}-0.2441 \\
(-1.08)\end{array}$ & $\begin{array}{c}-0.0384 \\
(-0.21)\end{array}$ & $\begin{array}{c}-0.0486 \\
(-0.39)\end{array}$ \\
\hline$d_{t}^{U S-}$ & $\begin{array}{c}0.1609 \\
(1.62)\end{array}$ & $\begin{array}{c}0.0082 \\
(0.13)\end{array}$ & $\begin{array}{c}0.0491 \\
(0.77)\end{array}$ & $\begin{array}{c}0.0204 \\
(0.28)\end{array}$ & $\begin{array}{c}0.0019 \\
(0.01)\end{array}$ & $\begin{array}{c}0.0966 \\
(0.44)\end{array}$ & $\begin{array}{c}0.1481 \\
(0.88)\end{array}$ & $\begin{array}{c}0.0861 \\
(0.60)\end{array}$ \\
\hline \multicolumn{9}{|c|}{ Economic environment } \\
\hline$\sigma_{m t}^{F X}$ & $\begin{array}{c}39.68^{* * *} \\
(4.16)\end{array}$ & $\begin{array}{c}7.7168^{* * *} \\
(4.66)\end{array}$ & $\begin{array}{c}-33.21^{* * *} \\
(-4.41)\end{array}$ & $\begin{array}{c}-14.85^{* * *} \\
(-2.74)\end{array}$ & $\begin{array}{l}95.22 \\
(0.07)\end{array}$ & $\begin{array}{l}94.51 \\
(0.83)\end{array}$ & $\begin{array}{l}-139.3 \\
(-1.61)\end{array}$ & $\begin{array}{c}-2.9209 \\
(-0.09)\end{array}$ \\
\hline$d_{m t}^{F X+}$ & $\begin{array}{c}-0.1179 \\
(-0.71)\end{array}$ & $\begin{array}{c}-0.0334 \\
(-0.64)\end{array}$ & $\begin{array}{c}0.0123 \\
(0.25)\end{array}$ & $\begin{array}{c}-0.0586 \\
(-0.67)\end{array}$ & $\begin{array}{c}0.0287 \\
(0.24)\end{array}$ & $\begin{array}{c}-0.0340 \\
(-0.16)\end{array}$ & $\begin{array}{c}0.0916 \\
(0.57)\end{array}$ & $\begin{array}{c}-0.0218 \\
(-0.17)\end{array}$ \\
\hline$d_{m t}^{F X-}$ & $\begin{array}{c}-0.1789 \\
(-1.40)\end{array}$ & $\begin{array}{c}0.0447 \\
(0.62)\end{array}$ & $\begin{array}{c}0.0166 \\
(0.26)\end{array}$ & $\begin{array}{c}0.0228 \\
(0.24)\end{array}$ & $\begin{array}{c}0.0449 \\
(0.25)\end{array}$ & $\begin{array}{c}-0.0510 \\
(-0.22)\end{array}$ & $\begin{array}{c}-0.1356 \\
(-0.65)\end{array}$ & $\begin{array}{c}-0.0282 \\
(-0.16)\end{array}$ \\
\hline$T_{t}^{m}$ & $\begin{array}{c}-0.1608 \\
(-0.08)\end{array}$ & $\begin{array}{c}-3.3730^{* * *} \\
(-2.55)\end{array}$ & $\begin{array}{c}-2.9894^{* * *} \\
(-2.97)\end{array}$ & n.a. & $\begin{array}{c}-1.1240^{* *} \\
(-2.21)\end{array}$ & $\begin{array}{c}-1.3260 \\
(-0.96)\end{array}$ & $\begin{array}{c}-3.1034 \\
(-0.35)\end{array}$ & $\begin{array}{c}2.8525^{* * *} \\
(6.93)\end{array}$ \\
\hline$C_{t}^{m}$ & $\begin{array}{c}-0.0410^{* *} \\
(-2.23)\end{array}$ & $\begin{array}{c}0.1786^{* * *} \\
(7.16)\end{array}$ & $\begin{array}{c}0.1555^{* * *} \\
(5.56)\end{array}$ & $\begin{array}{c}0.0851^{* * *} \\
\quad(4.46)\end{array}$ & $\begin{array}{c}0.1521^{* *} \\
(2.11)\end{array}$ & $\begin{array}{c}-0.0242 \\
(-0.14)\end{array}$ & $\begin{array}{c}-0.1724 \\
(-0.78)\end{array}$ & $\begin{array}{c}-0.0041 \\
(-0.29)\end{array}$ \\
\hline \multicolumn{9}{|c|}{ Financial integration } \\
\hline$I_{t}^{m}$ & n.a. & n.a. & n.a. & n.a. & n.a. & n.a. & n.a. & n.a. \\
\hline \multicolumn{9}{|c|}{ Investors' activity } \\
\hline$F_{t}^{m}$ & $\begin{array}{c}-0.0003 \\
(-1.10)\end{array}$ & $\begin{array}{c}-0.0001 \\
(-1.28)\end{array}$ & $\begin{array}{c}-0.0003 \\
(-1.06)\end{array}$ & $\begin{array}{c}-0.0002 \\
(-0.77)\end{array}$ & $\begin{array}{c}-0.00001 \\
(-0.19)\end{array}$ & $\begin{array}{c}-0.0013 \\
(-0.52)\end{array}$ & $\begin{array}{c}0.0016 \\
(1.55)\end{array}$ & $\begin{array}{r}-0.0007 \\
(-0.67)\end{array}$ \\
\hline \multicolumn{9}{|c|}{ Liquidity } \\
\hline$L_{t}^{m}$ & $\begin{array}{c}-0.1463^{* * *} \\
(-2.95)\end{array}$ & $\begin{array}{c}0.0226 \\
(0.82)\end{array}$ & $\begin{array}{c}0.9328 \\
(0.78)\end{array}$ & $\begin{array}{c}-0.0004 \\
(-1.29)\end{array}$ & $\begin{array}{c}0.0436 \\
(0.59)\end{array}$ & $\begin{array}{l}-54.75 \\
(-1.56)\end{array}$ & $\begin{array}{c}-0.3121 \\
(-0.10)\end{array}$ & $\begin{array}{l}13.01 \\
(1.05)\end{array}$ \\
\hline$L_{t}^{U S}$ & $\begin{array}{c}0.7352^{* * *} \\
(4.62)\end{array}$ & $\begin{array}{c}0.1014 \\
(0.91)\end{array}$ & $\begin{array}{c}0.3185^{* * *} \\
(2.94)\end{array}$ & $\begin{array}{c}0.3137^{* * *} \\
(2.63)\end{array}$ & $\begin{array}{c}0.1944 \\
(0.75)\end{array}$ & $\begin{array}{c}0.4797 \\
(1.11)\end{array}$ & $\begin{array}{c}0.0901 \\
(0.28)\end{array}$ & $\begin{array}{c}0.4589^{*} \\
(1.66)\end{array}$ \\
\hline \multicolumn{9}{|c|}{ Expected returns } \\
\hline$D_{t}^{m}$ & $\begin{array}{c}0.1487^{* * *} \\
(4.84)\end{array}$ & $\begin{array}{c}0.1154^{* * *} \\
(6.98)\end{array}$ & $\begin{array}{c}-0.2667^{* * *} \\
(-6.11)\end{array}$ & $\begin{array}{c}0.0155 \\
(0.62)\end{array}$ & $\begin{array}{c}0.1383 \\
(1.64)\end{array}$ & $\begin{array}{c}-0.2260 \\
(-0.88)\end{array}$ & $\begin{array}{c}-0.6431^{* * *} \\
(-2.59)\end{array}$ & $\begin{array}{c}0.1870^{*} \\
(1.80)\end{array}$ \\
\hline$D_{t}^{U S}$ & $\begin{array}{c}-2.4326^{* * *} \\
(-9.19) \\
\end{array}$ & $\begin{array}{c}-1.7685^{* * *} \\
(13.92) \\
\end{array}$ & $\begin{array}{c}-0.2369^{* * *} \\
(-3.55) \\
\end{array}$ & $\begin{array}{c}-0.9133^{* * *} \\
(-7.61) \\
\end{array}$ & $\begin{array}{c}-1.0599^{* * *} \\
(-2.73) \\
\end{array}$ & $\begin{array}{c}-1.9280^{* * *} \\
(-2.63)\end{array}$ & $\begin{array}{c}1.2889 \\
(1.51) \\
\end{array}$ & $\begin{array}{c}-2.4323^{* * *} \\
(-6.96)\end{array}$ \\
\hline$t_{0}$ & $12 / 7 / 93$ & $3 / 15 / 94$ & $11 / 28 / 89$ & $12 / 21 / 93$ & $11 / 19 / 96$ & $4 / 14 / 98$ & $7 / 14 / 98$ & $3 / 21 / 95$ \\
\hline$N$ & 487 & 473 & 697 & 485 & 333 & 260 & 247 & 420 \\
\hline$R_{P}^{2}$ & $94.24 \%$ & $95.16 \%$ & $95.23 \%$ & $90.23 \%$ & $32.92 \%$ & $41.91 \%$ & $63.04 \%$ & $81.68 \%$ \\
\hline$R_{D}^{2}$ & $92.17 \%$ & $95.58 \%$ & $94.85 \%$ & $91.40 \%$ & $51.59 \%$ & $57.70 \%$ & $70.03 \%$ & $85.64 \%$ \\
\hline$\chi^{2}$ & $\begin{array}{c}140.2^{* * *} \\
(0.0000) \\
\end{array}$ & $\begin{array}{c}102.7^{* * *} \\
(0.0000) \\
\end{array}$ & $\begin{array}{c}92.52^{* * *} \\
(0.0000) \\
\end{array}$ & $\begin{array}{c}95.83^{* * *} \\
(0.0000) \\
\end{array}$ & $\begin{array}{c}38.63^{* * *} \\
(0.0007) \\
\end{array}$ & $\begin{array}{l}27.88^{* *} \\
(0.0223) \\
\end{array}$ & $\begin{array}{c}37.28^{* * *} \\
(0.0012) \\
\end{array}$ & $\begin{array}{c}52.79^{* * *} \\
(0.0000) \\
\end{array}$ \\
\hline
\end{tabular}


Table 4 (Continued).

\begin{tabular}{|c|c|c|c|c|c|c|c|}
\hline & Israel & Mexico & Philippines & Russia & S. Africa & S. Korea & Venezuela \\
\hline \multicolumn{8}{|c|}{ Information } \\
\hline$\sigma_{t}^{m}$ & $\begin{array}{c}-44.08^{* *} \\
(-2.42)\end{array}$ & $\begin{array}{c}-16.71^{* * *} \\
(-4.32)\end{array}$ & $\begin{array}{c}-9.3947 \\
(-0.62)\end{array}$ & $\begin{array}{c}-14.48^{*} \\
(-1.84)\end{array}$ & $\begin{array}{c}4.0104 \\
(1.35)\end{array}$ & $\begin{array}{c}-25.20^{* * *} \\
(-3.26)\end{array}$ & $\begin{array}{c}-213.0^{* * *} \\
(-3.21)\end{array}$ \\
\hline$\sigma_{t}^{U S}$ & $\begin{array}{c}46.34^{* * *} \\
(3.42)\end{array}$ & $\begin{array}{c}25.54^{* * *} \\
(4.84)\end{array}$ & $\begin{array}{l}-21.21 \\
(-0.94)\end{array}$ & $\begin{array}{c}72.14^{* * *} \\
(3.01)\end{array}$ & $\begin{array}{c}-0.0310 \\
(-0.01)\end{array}$ & $\begin{array}{l}19.45 \\
(1.46)\end{array}$ & $\begin{array}{c}141.5^{* *} \\
(2.08)\end{array}$ \\
\hline \multicolumn{8}{|l|}{ Trend } \\
\hline$d_{t}^{m+}$ & $\begin{array}{c}-0.0301 \\
(-0.29)\end{array}$ & $\begin{array}{c}0.0286 \\
(0.61)\end{array}$ & $\begin{array}{c}-0.1664 \\
(-0.98)\end{array}$ & $\begin{array}{c}0.0392 \\
(0.31)\end{array}$ & $\begin{array}{c}0.0073 \\
(0.15)\end{array}$ & $\begin{array}{c}0.0462 \\
(0.38)\end{array}$ & $\begin{array}{c}-0.5077 \\
(-0.85)\end{array}$ \\
\hline$d_{t}^{m-}$ & $\begin{array}{c}0.0153 \\
(0.12)\end{array}$ & $\begin{array}{c}0.0332 \\
(0.60)\end{array}$ & $\begin{array}{c}-0.0143 \\
(-0.11)\end{array}$ & $\begin{array}{c}0.0318 \\
(0.22)\end{array}$ & $\begin{array}{c}0.0125 \\
(0.22)\end{array}$ & $\begin{array}{c}-0.0412 \\
(-0.32)\end{array}$ & $\begin{array}{c}-0.2263 \\
(-0.59)\end{array}$ \\
\hline$d_{t}^{U S+}$ & $\begin{array}{r}-0.0687 \\
(-0.66)\end{array}$ & $\begin{array}{c}-0.0397 \\
(-0.93)\end{array}$ & $\begin{array}{c}0.0512 \\
(0.38)\end{array}$ & $\begin{array}{c}-0.0408 \\
(-0.30)\end{array}$ & $\begin{array}{c}0.0041 \\
(0.09)\end{array}$ & $\begin{array}{c}-0.0497 \\
(-0.48)\end{array}$ & $\begin{array}{c}0.5241 \\
(0.94)\end{array}$ \\
\hline$d_{t}^{U S-}$ & $\begin{array}{c}-0.0079 \\
(-0.06)\end{array}$ & $\begin{array}{c}0.0334 \\
(0.63)\end{array}$ & $\begin{array}{c}-0.0564 \\
(-0.31)\end{array}$ & $\begin{array}{c}0.0803 \\
(0.52)\end{array}$ & $\begin{array}{c}0.0187 \\
(0.28)\end{array}$ & $\begin{array}{c}0.0149 \\
(0.11)\end{array}$ & $\begin{array}{c}0.3339 \\
(0.90)\end{array}$ \\
\hline \multicolumn{8}{|c|}{ Economic environment } \\
\hline$\sigma_{m t}^{F X}$ & $\begin{array}{c}-6.9853 \\
(-0.25)\end{array}$ & $\begin{array}{c}21.99^{* * *} \\
(8.63)\end{array}$ & $\begin{array}{c}1.6587 \\
(0.12)\end{array}$ & $\begin{array}{c}7.7446^{* * *} \\
(3.19)\end{array}$ & $\begin{array}{c}-0.0811 \\
(-0.03)\end{array}$ & $\begin{array}{c}21.22^{* * *} \\
(3.50)\end{array}$ & $\begin{array}{l}20.04 \\
(0.68)\end{array}$ \\
\hline$d_{m t}^{F X+}$ & $\begin{array}{c}-0.0560 \\
(-0.48)\end{array}$ & $\begin{array}{c}0.0143 \\
(0.30)\end{array}$ & $\begin{array}{c}-0.0850 \\
(-0.62)\end{array}$ & $\begin{array}{c}-0.1592 \\
(-1.33)\end{array}$ & $\begin{array}{c}-0.0102 \\
(-0.21)\end{array}$ & $\begin{array}{c}0.0539 \\
(0.49)\end{array}$ & $\begin{array}{c}-0.1665 \\
(-0.50)\end{array}$ \\
\hline$d_{m t}^{F X-}$ & $\begin{array}{c}0.1057 \\
(0.94)\end{array}$ & $\begin{array}{c}0.0048 \\
(0.09)\end{array}$ & $\begin{array}{c}0.0487 \\
(0.24)\end{array}$ & $\begin{array}{c}-0.2250 \\
(-1.45)\end{array}$ & $\begin{array}{c}-0.0097 \\
(-0.16)\end{array}$ & $\begin{array}{c}0.0202 \\
(0.18)\end{array}$ & $\begin{array}{c}-0.1215 \\
(-0.25)\end{array}$ \\
\hline$T_{t}^{m}$ & $\begin{array}{c}-6.7476^{* * *} \\
(-5.85)\end{array}$ & $\begin{array}{l}1.0543^{* * *} \\
(2.84)\end{array}$ & $\begin{array}{c}3.2825^{* * *} \\
(2.71)\end{array}$ & $\begin{array}{c}0.4027 \\
(0.27)\end{array}$ & $\begin{array}{c}-1.8805^{* * *} \\
(-3.47)\end{array}$ & $\begin{array}{c}1.4954^{*} \\
(1.95)\end{array}$ & $\begin{array}{c}4.9430 \\
(0.37)\end{array}$ \\
\hline$C_{t}^{m}$ & $\begin{array}{c}0.3621^{* * *} \\
(6.92)\end{array}$ & $\begin{array}{c}0.1780^{* * *} \\
(7.31)\end{array}$ & $\begin{array}{c}-0.4516^{* * *} \\
(-2.95)\end{array}$ & $\begin{array}{c}0.0172 \\
(0.69)\end{array}$ & $\begin{array}{c}0.1716^{* * *} \\
(11.18)\end{array}$ & $\begin{array}{c}0.0752^{* * *} \\
(2.76)\end{array}$ & $\begin{array}{c}0.2422 \\
(0.99)\end{array}$ \\
\hline \multicolumn{8}{|c|}{ Financial integration } \\
\hline$I_{t}^{m}$ & n.a. & n.a. & $\begin{array}{c}5.6480^{* *} \\
(2.47)\end{array}$ & n.a. & n.a. & n.a. & n.a. \\
\hline \multicolumn{8}{|c|}{ Investors' activity } \\
\hline$F_{t}^{m}$ & $\begin{array}{c}0.00005 \\
(0.23)\end{array}$ & $\begin{array}{c}0.00004 \\
(0.54)\end{array}$ & $\begin{array}{c}0.0007 \\
(0.44)\end{array}$ & $\begin{array}{c}0.0008 \\
(0.56)\end{array}$ & $\begin{array}{c}0.0003 \\
(1.20)\end{array}$ & $\begin{array}{c}0.00003 \\
(0.22)\end{array}$ & $\begin{array}{c}-0.0010 \\
(-0.21)\end{array}$ \\
\hline \multicolumn{8}{|c|}{ Liquidity } \\
\hline$L_{t}^{m}$ & n.a. & $\begin{array}{c}-0.4897^{* * *} \\
(-5.95)\end{array}$ & $\begin{array}{c}-0.1434 \\
(-0.89)\end{array}$ & $\begin{array}{c}0.0001 \\
(0.12)\end{array}$ & $\begin{array}{c}-0.0360 \\
(-0.19)\end{array}$ & $\begin{array}{c}-3.3398 \\
(-0.18)\end{array}$ & $\begin{array}{c}-9.7260 \\
(-0.57)\end{array}$ \\
\hline$L_{t}^{U S}$ & $\begin{array}{c}0.4624^{* *} \\
(2.13)\end{array}$ & $\begin{array}{c}0.5387^{* * *} \\
(6.78)\end{array}$ & $\begin{array}{c}0.4301 \\
(1.35)\end{array}$ & $\begin{array}{c}0.4865^{*} \\
(1.85)\end{array}$ & $\begin{array}{c}0.4605^{* * *} \\
(3.74)\end{array}$ & $\begin{array}{c}0.2083 \\
(0.88)\end{array}$ & $\begin{array}{c}0.4482 \\
(0.81)\end{array}$ \\
\hline \multicolumn{8}{|c|}{ Expected returns } \\
\hline$D_{t}^{m}$ & n.a. & $\begin{array}{c}-0.4309^{* * *} \\
(-6.08)\end{array}$ & $\begin{array}{c}0.2433 \\
(1.13)\end{array}$ & $\begin{array}{c}-0.1540^{*} \\
(-1.93)\end{array}$ & $\begin{array}{c}-0.0881^{* *} \\
(-2.50)\end{array}$ & $\begin{array}{c}0.0299 \\
(0.33)\end{array}$ & $\begin{array}{c}0.0697 \\
(0.56)\end{array}$ \\
\hline$D_{t}^{U S}$ & $\begin{array}{c}-0.9564^{* * *} \\
(-6.35)\end{array}$ & $\begin{array}{c}-0.6964^{* * *} \\
(-7.14)\end{array}$ & $\begin{array}{c}-1.1073^{* * *} \\
(-3.62)\end{array}$ & $\begin{array}{c}-1.0930^{* * *} \\
(-3.29)\end{array}$ & $\begin{array}{c}-0.3071^{* * *} \\
(-8.35)\end{array}$ & $\begin{array}{c}-1.1563^{* * *} \\
(-4.46)\end{array}$ & $\begin{array}{c}-2.4646 \\
(-1.35) \\
\end{array}$ \\
\hline$t_{0}$ & $6 / 1 / 93$ & $5 / 31 / 88$ & 2/9/88 & $6 / 3 / 97$ & $5 / 27 / 80$ & $3 / 14 / 95$ & $8 / 17 / 93$ \\
\hline$N$ & 566 & 775 & 791 & 305 & 1,210 & 421 & 503 \\
\hline$R_{P}^{2}$ & $74.52 \%$ & $90.29 \%$ & $78.71 \%$ & $53.57 \%$ & $83.76 \%$ & $69.08 \%$ & $92.37 \%$ \\
\hline$R_{D}^{2}$ & $80.47 \%$ & $91.03 \%$ & $81.59 \%$ & $66.83 \%$ & $82.93 \%$ & $70.88 \%$ & $88.50 \%$ \\
\hline$\chi^{2}$ & $\begin{array}{c}113.9^{* * *} \\
(0.0000) \\
\end{array}$ & $\begin{array}{c}447.5^{* * *} \\
(0.0006) \\
\end{array}$ & $\begin{array}{c}80.03^{* * *} \\
(0.0000) \\
\end{array}$ & $\begin{array}{c}59.43^{* * *} \\
(0.0003) \\
\end{array}$ & $\begin{array}{c}207.0^{* * *} \\
(0.0000) \\
\end{array}$ & $\begin{array}{c}19.79 \\
(0.1802) \\
\end{array}$ & $\begin{array}{c}33.27^{* * *} \\
(0.0043) \\
\end{array}$ \\
\hline
\end{tabular}




\section{Table 5. Contagion tests}

This table reports estimates for the contagion measure $C M_{t}(l)$ of Eq. (9),

$$
C M_{t}(l)=\left\{B_{t}(l)-E_{t-1}\left[B_{t}(l)\right]\right\}-E\left\{B_{t}^{*}(l)-E\left[B_{t}^{*}(l)\right]\right\},
$$

where $l=E$ or $P, B_{t}(l)=\sum_{m=1}^{n_{t}(l)} \frac{V_{t}^{m}(l)}{n_{t}(l)}, n_{t}(l) \geq 2$ is the number of countries in the sample for which the variable $Y_{t}^{m}$ of Section 6.7 is available at time $t, V_{t}^{m}(l)=1$ if $Y_{t}^{m}>\hat{\lambda}_{t}^{m}$ and equal to zero otherwise, $E\left\{B_{t}^{*}(l)-E\left[B_{t}^{*}(l)\right]\right\}=\sum_{m=0}^{n_{t}(l)} \frac{m-0.5}{n_{t}(l)}\left(\begin{array}{c}n_{t}(l) \\ m\end{array}\right) 0.5^{n_{t}(l)\left[n_{t}(l)-m\right]}$, and $E_{t-1}\left[B_{t}(l)\right]$ is a rolling average of over its past 12 realizations. $C M_{t}(l)$ is constructed across the efficiency (Panel A) and pricing (Panel B) breaks reported in Tables 1 and 2 and over different subintervals of the sample Mean is the average, Median is the median, and Stdev is the standard deviation of $C M_{t}(l)$ over the corresponding sample period, while t-stat is the resulting $t$-statistic. A "**, "**”, or "***" indicate significance at the $10 \%, 5 \%$, or $1 \%$ level, respectively. Finally, the column labeled p-one contains $p$-values for the one-sided test $H_{0}: C M_{t}(l) \leq 0$ versus the alternative hypothesis $H_{1}: C M_{t}(l)>0$; clearly, no observed negative mean value of $C M_{t}(l)$ can lead to the rejection of $H_{0}$.

\begin{tabular}{cccccc}
\hline \hline & \multicolumn{5}{c}{ Panel A: $C M_{t}(E)$} \\
\cline { 2 - 6 } Interval & Mean & Median & Stdev & t-stat & p-one \\
\hline $05 / 88-04 / 03$ & $0.54 \%$ & $0.00 \%$ & $13.58 \%$ & 1.10 & $13.49 \%$ \\
$05 / 88-12 / 93$ & $0.54 \%$ & $0.00 \%$ & $15.04 \%$ & 0.62 & $26.73 \%$ \\
$01 / 94-12 / 95$ & $0.74 \%$ & $-0.70 \%$ & $8.94 \%$ & 0.85 & $19.89 \%$ \\
$01 / 96-12 / 97$ & $-0.74 \%$ & $-2.08 \%$ & $7.03 \%$ & -1.08 & n.a. \\
$01 / 98-12 / 99$ & $0.83 \%$ & $0.99 \%$ & $8.48 \%$ & 1.00 & $16.02 \%$ \\
$01 / 00-04 / 03$ & $1.01 \%$ & $0.52 \%$ & $18.18 \%$ & 0.73 & $23.46 \%$ \\
\hline & & Panel B: $C M_{t}(P)$ & \\
\cline { 2 - 6 } Interval & Mean & Median & Stdev & t-stat & p-one \\
\hline $05 / 88-04 / 03$ & $0.60 \%$ & $0.00 \%$ & $12.16 \%$ & 1.37 & $8.58 \%$ \\
$05 / 88-12 / 93$ & $0.63 \%$ & $0.00 \%$ & $10.79 \%$ & 1.01 & $15.64 \%$ \\
$01 / 94-12 / 95$ & $1.26 \% *$ & $0.56 \%$ & $7.64 \%$ & 1.69 & $4.75 \%$ \\
$01 / 96-12 / 97$ & $0.20 \%$ & $0.01 \%$ & $6.83 \%$ & 0.30 & $38.17 \%$ \\
$01 / 98-12 / 99$ & $0.37 \%$ & $1.11 \%$ & $9.88 \%$ & 0.38 & $35.31 \%$ \\
$01 / 00-04 / 03$ & $0.51 \%$ & $1.11 \%$ & $18.80 \%$ & 0.35 & $36.28 \%$ \\
\hline \hline
\end{tabular}


Table 6. Capital controls test

This table reports OLS estimates for the following country-level regressions of the difference between the actual number of companies in country $m$ whose ADRs are experiencing either an efficiency $\left(Y_{t}^{m}=E_{t}^{m}\right)$ or pricing $\left(Y_{t}^{m}=P_{t}^{m}\right)$ break at time $t$ and the corresponding estimated number from the model of Eqs. (7) and (8), $\hat{\lambda}_{t}^{m}$, on two measures of intertemporal shifts in the intensity of capital controls in country $m$ (Eq. (10)):

$$
Y_{t}^{m}-\widehat{\lambda}_{t}^{m}=\delta_{0}^{m}+\delta_{1}^{m} \Delta C I_{t}^{m}+\delta_{2}^{m} \Delta E W_{t}^{m}+u_{t}^{m}
$$

where $\Delta C I_{t}^{m}$ is the first difference of the capital controls index of Chinn and Ito (2002) and $\Delta E W_{t}^{m}$ is the first difference of the smoothed market closeness index of Edison and Warnock (2003). Each index is adjusted so that a positive change reflects more intense capital controls. Both indexes are available only until December 2000. For each estimate we report the $t$-statistic in parentheses. A "**, "**", or " *** " indicate significance at the $10 \%$, $5 \%$, or $1 \%$ level, respectively. $R^{2}$ is the coefficient of determination; $N$ is the number of observations.

\begin{tabular}{|c|c|c|c|c|c|c|c|c|c|}
\hline \multirow[b]{2}{*}{ Country } & \multirow[b]{2}{*}{$N$} & \multicolumn{4}{|c|}{ Efficiency breaks: $Y_{t}^{m}=E_{t}^{m}$} & \multicolumn{4}{|c|}{ Pricing breaks: $Y_{t}^{m}=P_{t}^{m}$} \\
\hline & & $\delta_{0}^{m}$ & $\Delta C I_{t}^{m}$ & $\Delta E W_{t}^{m}$ & $R^{2}$ & $\delta_{0}^{m}$ & $\Delta C I_{t}^{m}$ & $\Delta E W_{t}^{m}$ & $R^{2}$ \\
\hline Argentina & 369 & $\begin{array}{c}-0.0478^{* * *} \\
(-22.17)\end{array}$ & $\begin{array}{c}-0.0119^{* * *} \\
(-3.32)\end{array}$ & $\begin{array}{l}-5.2864^{* * *} \\
(-4.05)\end{array}$ & $7.54 \%$ & $\begin{array}{c}-0.0545^{* * *} \\
(-2.91)\end{array}$ & $\begin{array}{c}-0.0276 \\
(-0.89)\end{array}$ & $\begin{array}{c}59.62^{* * *} \\
(5.27)\end{array}$ & $7.09 \%$ \\
\hline Brazil & 355 & $\begin{array}{c}-0.0377 \\
(-1.05)\end{array}$ & $\begin{array}{c}-0.1470 \\
(-1.07)\end{array}$ & $\begin{array}{c}1.3252 \\
(0.64)\end{array}$ & $0.43 \%$ & $\begin{array}{c}0.0647 \\
(1.36)\end{array}$ & $\begin{array}{c}-0.3158^{*} \\
(-1.73)\end{array}$ & $\begin{array}{c}4.7598^{*} \\
(1.74)\end{array}$ & $7.54 \%$ \\
\hline Chile & 579 & $\begin{array}{c}-0.0129 \\
(-0.57)\end{array}$ & $\begin{array}{c}0.0844^{* * *} \\
(4.05)\end{array}$ & $\begin{array}{c}0.3094 \\
(0.81)\end{array}$ & $2.88 \%$ & $\begin{array}{c}-0.0410^{*} \\
(-1.68)\end{array}$ & $\begin{array}{c}-0.0989^{* * *} \\
(-4.39)\end{array}$ & $\begin{array}{c}-0.2648 \\
(-0.64)\end{array}$ & $3.30 \%$ \\
\hline China & 367 & $\begin{array}{c}-0.0997 \\
(-1.63)\end{array}$ & $\begin{array}{c}0.3201 \\
(0.26)\end{array}$ & $\begin{array}{c}0.2027 \\
(0.25)\end{array}$ & $0.04 \%$ & $\begin{array}{c}-0.0440 \\
(-1.30)\end{array}$ & $\begin{array}{c}0.8582 \\
(1.28)\end{array}$ & $\begin{array}{c}-0.5704 \\
(-1.26)\end{array}$ & $0.89 \%$ \\
\hline Hungary & 142 & n.a. & n.a. & n.a. & n.a. & $\begin{array}{c}-0.0161 \\
(-0.65)\end{array}$ & n.a. & $\begin{array}{l}55.93 \\
(1.12)\end{array}$ & $0.88 \%$ \\
\hline India & 129 & $\begin{array}{c}-0.0461^{* * *} \\
(-4.99)\end{array}$ & $\begin{array}{c}0.0420^{* * *} \\
(3.09)\end{array}$ & $\begin{array}{c}-0.2008 \\
(-0.14)\end{array}$ & $7.04 \%$ & $\begin{array}{c}-0.0115 \\
(-0.28)\end{array}$ & $\begin{array}{c}0.1365^{* *} \\
(2.24)\end{array}$ & $\begin{array}{c}-18.07^{* * *} \\
(-2.81)\end{array}$ & $9.28 \%$ \\
\hline Indonesia & 302 & $\begin{array}{c}0.0456^{*} \\
(1.71)\end{array}$ & $\begin{array}{c}-0.3593^{* * *} \\
(-6.39)\end{array}$ & $\begin{array}{c}0.6672 \\
(1.08)\end{array}$ & $12.32 \%$ & $\begin{array}{c}0.0452^{*} \\
(1.75)\end{array}$ & $\begin{array}{c}-0.3443^{* * *} \\
(-6.32)\end{array}$ & $\begin{array}{c}0.7876 \\
(1.32)\end{array}$ & $12.24 \%$ \\
\hline Israel & 448 & $\begin{array}{c}-0.0647^{* * *} \\
(-4.46)\end{array}$ & $\begin{array}{c}-0.1610^{* * *} \\
(-10.24)\end{array}$ & n.a. & $19.02 \%$ & $\begin{array}{c}0.0270^{*} \\
(1.88)\end{array}$ & $\begin{array}{c}0.0438^{* * *} \\
(2.81)\end{array}$ & n.a. & $1.74 \%$ \\
\hline Mexico & 621 & $\begin{array}{c}-0.1244^{* * *} \\
(-4.46)\end{array}$ & $\begin{array}{c}-0.0028 \\
(-0.06)\end{array}$ & $\begin{array}{c}-1.4890^{* *} \\
(-2.02)\end{array}$ & $0.65 \%$ & $\begin{array}{c}-0.0776 \\
(-1.34)\end{array}$ & $\begin{array}{c}0.0697 \\
(0.70)\end{array}$ & $\begin{array}{c}0.0996 \\
(0.06)\end{array}$ & $0.08 \%$ \\
\hline Peru & 220 & $\begin{array}{c}-0.0030 \\
(-0.15)\end{array}$ & $\begin{array}{c}0.0647^{*} \\
(1.80)\end{array}$ & $\begin{array}{c}-1.8164 \\
(-0.75)\end{array}$ & $1.73 \%$ & n.a. & n.a. & n.a. & n.a. \\
\hline Philippines & 621 & $\begin{array}{c}-0.0213^{* *} \\
(-2.14)\end{array}$ & $\begin{array}{c}-0.0929^{* * *} \\
(-5.79)\end{array}$ & $\begin{array}{c}0.5076 \\
(0.49)\end{array}$ & $5.16 \%$ & $\begin{array}{c}-0.0152 \\
(-1.50)\end{array}$ & $\begin{array}{c}-0.0550^{* * *} \\
(-3.38)\end{array}$ & $\begin{array}{c}0.4662 \\
(0.45)\end{array}$ & $1.84 \%$ \\
\hline Russia & 187 & $\begin{array}{c}-0.1136^{* *} \\
(-2.49)\end{array}$ & n.a. & $\begin{array}{c}10.38^{* * *} \\
(4.24)\end{array}$ & $8.85 \%$ & $\begin{array}{c}-0.0787^{* *} \\
(-1.97)\end{array}$ & n.a. & $\begin{array}{c}8.3441^{* * *} \\
(3.88)\end{array}$ & $7.54 \%$ \\
\hline S. Africa & 417 & $\begin{array}{c}-0.1101^{* * *} \\
(-8.43)\end{array}$ & $\begin{array}{c}0.0369^{* *} \\
(2.02)\end{array}$ & $\begin{array}{c}2.2411 \\
(0.76)\end{array}$ & $1.11 \%$ & $\begin{array}{c}0.1625^{* * *} \\
(6.77)\end{array}$ & $\begin{array}{c}0.6628^{* * *} \\
(19.72)\end{array}$ & $\begin{array}{c}21.92^{* * *} \\
(4.05)\end{array}$ & $49.53 \%$ \\
\hline S. Korea & 303 & $\begin{array}{c}-0.0069 \\
(-0.17)\end{array}$ & $\begin{array}{c}-0.1292^{*} \\
(-1.88)\end{array}$ & $\begin{array}{c}-1.5207^{* * *} \\
(-2.64)\end{array}$ & $3.48 \%$ & $\begin{array}{c}0.0447^{* *} \\
(2.18)\end{array}$ & $\begin{array}{c}-0.1293^{* * *} \\
(-3.84)\end{array}$ & $\begin{array}{c}-0.2151 \\
(-0.76)\end{array}$ & $4.91 \%$ \\
\hline Venezuela & 385 & $\begin{array}{c}-0.0177^{* * *} \\
(-10.57) \\
\end{array}$ & n.a. & $\begin{array}{c}-0.2276^{* * *} \\
(-5.40) \\
\end{array}$ & $7.09 \%$ & $\begin{array}{c}-0.0033^{* * *} \\
(-11.34) \\
\end{array}$ & n.a. & $\begin{array}{c}-0.0138^{*} \\
(-1.90) \\
\end{array}$ & $0.93 \%$ \\
\hline
\end{tabular}




\section{Table 7. Legal protection tests: Country level}

This table reports estimates of the cross-country covariation between the percentage of ADRs experiencing efficiency (eff) or pricing (pri) breaks in a country (i.e., $N^{*} / N$ from Tables 1a and 2a, respectively) and the corresponding degree of investor protection and corporate governance. We measure the latter for each country using the rankings for legal enforcement of investor protection developed by La Porta et al. (1998) — Efficiency of judicial system, Rule of law, Corruption, Risk of expropriation, Risk of contract repudiation, and Rating on accounting standards - and the corporate governance macro rankings developed by Credit Lyonnais Securities Asia (CLSA, 2001) - Rules and regulations, Enforcement and regulation, Political/regulatory environment, Adoption of IGAAP, Institutional mechanisms and corporate governance culture, and a corresponding Weighted index when available $(n)$; in both cases, the higher is the realization of a variable, the greater is the degree of (legal and/or factual) investor protection. We use three measures of covariation: Pearson parametric correlation $\left(\rho_{e f f}\right.$ and $\left.\rho_{\text {pri }}\right)$, Spearman rank-order correlation $\left(\rho_{e f f}^{s p}\right.$ and $\left.\rho_{p r i}^{s p}\right)$, and Pearson partial correlations $\left(r_{e f f}\right.$ and $\left.r_{p r i}\right)$. For each estimate we report the $p$-value for the test of the null hypothesis that the correlation is zero. A "* ", " ** ", or "***" indicate the null hypothesis is rejected at the $10 \%, 5 \%$, or $1 \%$ significance level, respectively.

\begin{tabular}{|c|c|c|c|c|c|c|c|}
\hline \multirow[b]{2}{*}{ Indicators } & \multicolumn{7}{|c|}{ Legal protection \& country-grouped breaks } \\
\hline & $n$ & $\rho_{e f f}$ & $\rho_{\text {pri }}$ & $\rho_{e f f}^{s p}$ & $\rho_{p r i}^{s p}$ & $r_{e f f}$ & $r_{\text {pri }}$ \\
\hline $\begin{array}{l}\text { Efficiency of } \\
\text { judicial system }\end{array}$ & 16 & $\begin{array}{r}-0.4135 \\
(0.1114)\end{array}$ & $\begin{array}{l}-0.3703 \\
(0.1580)\end{array}$ & $\begin{array}{c}-0.4511^{*} \\
(0.0795)\end{array}$ & $\begin{array}{c}-0.4532^{*} \\
(0.0779)\end{array}$ & $\begin{array}{l}-0.5044 \\
(0.4956)\end{array}$ & $\begin{array}{r}-0.8829 \\
(0.1171)\end{array}$ \\
\hline $\begin{array}{l}\text { Rule of } \\
\text { law }\end{array}$ & 16 & $\begin{array}{c}-0.2359 \\
(0.3790)\end{array}$ & $\begin{array}{r}-0.0987 \\
(0.7163)\end{array}$ & $\begin{array}{c}-0.1484 \\
(0.5834)\end{array}$ & $\begin{array}{c}-0.0074 \\
(0.9782)\end{array}$ & $\begin{array}{l}0.6041 \\
(0.3959)\end{array}$ & $\begin{array}{l}0.9463^{*} \\
(0.0537)\end{array}$ \\
\hline Corruption & 16 & $\begin{array}{r}-0.3981 \\
(0.1267)\end{array}$ & $\begin{array}{l}-0.3087 \\
(0.2446)\end{array}$ & $\begin{array}{c}-0.3452 \\
(0.1904)\end{array}$ & $\begin{array}{c}-0.1798 \\
(0.5052)\end{array}$ & $\begin{array}{c}-0.4188 \\
(0.5812)\end{array}$ & $\begin{array}{r}-0.8991 \\
(0.1009)\end{array}$ \\
\hline $\begin{array}{l}\text { Risk of } \\
\text { expropriation }\end{array}$ & 16 & $\begin{array}{c}-0.4818^{*} \\
(0.0588)\end{array}$ & $\begin{array}{c}-0.3354 \\
(0.2040)\end{array}$ & $\begin{array}{c}-0.4911^{*} \\
(0.0534)\end{array}$ & $\begin{array}{c}-0.3576 \\
(0.1739)\end{array}$ & $\begin{array}{l}0.4015 \\
(0.5985)\end{array}$ & $\begin{array}{l}0.8867 \\
(0.1133)\end{array}$ \\
\hline $\begin{array}{l}\text { Risk of contract } \\
\text { repudiation }\end{array}$ & 16 & $\begin{array}{r}-0.4188 \\
(0.1064)\end{array}$ & $\begin{array}{r}-0.3211 \\
(0.2253)\end{array}$ & $\begin{array}{l}-0.3449 \\
(0.1907)\end{array}$ & $\begin{array}{c}-0.2658 \\
(0.3198)\end{array}$ & $\begin{array}{l}-0.5373 \\
(0.4627)\end{array}$ & $\begin{array}{r}-0.9385^{*} \\
(0.0615)\end{array}$ \\
\hline $\begin{array}{l}\text { Accounting } \\
\text { standards }\end{array}$ & 15 & $\begin{array}{c}-0.1003 \\
(0.7221)\end{array}$ & $\begin{array}{r}-0.2541 \\
(0.3608)\end{array}$ & $\begin{array}{c}-0.0045 \\
(0.9873)\end{array}$ & $\begin{array}{c}-0.2013 \\
(0.4720)\end{array}$ & $\begin{array}{l}0.5597 \\
(0.4403)\end{array}$ & $\begin{array}{c}0.9524^{* *} \\
(0.0476)\end{array}$ \\
\hline $\begin{array}{l}\text { Rules and } \\
\text { regulations }\end{array}$ & 19 & $\begin{array}{c}-0.6151^{* * *} \\
(0.0051)\end{array}$ & $\begin{array}{r}-0.3267 \\
(0.1721)\end{array}$ & $\begin{array}{c}-0.5916^{* * *} \\
(0.0076)\end{array}$ & $\begin{array}{c}-0.3332 \\
(0.1633)\end{array}$ & $\begin{array}{l}0.3121 \\
(0.6879)\end{array}$ & $\begin{array}{l}0.8439 \\
(0.1561)\end{array}$ \\
\hline $\begin{array}{l}\text { Enforcement } \\
\text { and regulation }\end{array}$ & 19 & $\begin{array}{c}-0.4716^{* *} \\
(0.0415)\end{array}$ & $\begin{array}{c}-0.3000 \\
(0.2121)\end{array}$ & $\begin{array}{c}-0.4621^{* *} \\
(0.0464)\end{array}$ & $\begin{array}{c}-0.2511 \\
(0.2998)\end{array}$ & $\begin{array}{l}0.4148 \\
(0.5852)\end{array}$ & $\begin{array}{l}0.7025 \\
(0.2976)\end{array}$ \\
\hline $\begin{array}{l}\text { Political/regulatory } \\
\text { environment }\end{array}$ & 19 & $\begin{array}{c}-0.4053^{*} \\
(0.0851)\end{array}$ & $\begin{array}{r}-0.1407 \\
(0.5656)\end{array}$ & $\begin{array}{r}-0.3262 \\
(0.1729)\end{array}$ & $\begin{array}{c}-0.0038 \\
(0.9878)\end{array}$ & $\begin{array}{r}-0.2367 \\
(0.7633)\end{array}$ & $\begin{array}{r}-0.0700 \\
(0.9300)\end{array}$ \\
\hline $\begin{array}{l}\text { Adoption } \\
\text { of IGAAP }\end{array}$ & 19 & $\begin{array}{c}-0.1305 \\
(0.5945)\end{array}$ & $\begin{array}{l}-0.1260 \\
(0.6073)\end{array}$ & $\begin{array}{c}-0.1733 \\
(0.4781)\end{array}$ & $\begin{array}{c}-0.1588 \\
(0.5160)\end{array}$ & $\begin{array}{l}0.4873 \\
(0.5126)\end{array}$ & $\begin{array}{c}0.9026^{*} \\
(0.0974)\end{array}$ \\
\hline $\begin{array}{l}\text { Institutional mecha- } \\
\text { nisms and culture }\end{array}$ & 19 & $\begin{array}{c}-0.5132^{* *} \\
(0.0246)\end{array}$ & $\begin{array}{c}-0.2170 \\
(0.3722)\end{array}$ & $\begin{array}{c}-0.5071^{* *} \\
(0.0267)\end{array}$ & $\begin{array}{c}-0.2140 \\
(0.3791)\end{array}$ & $\begin{array}{r}-0.5407 \\
(0.4593)\end{array}$ & $\begin{array}{c}-0.9273^{*} \\
(0.0727)\end{array}$ \\
\hline $\begin{array}{l}\text { Weighted } \\
\text { score }\end{array}$ & 19 & $\begin{array}{c}-0.4733^{* *} \\
(0.0407)\end{array}$ & $\begin{array}{c}-0.2558 \\
(0.2906)\end{array}$ & $\begin{array}{c}-0.4331^{*} \\
(0.0640)\end{array}$ & $\begin{array}{c}-0.2522 \\
(0.2975)\end{array}$ & n.a. & n.a. \\
\hline
\end{tabular}




\section{Table 8. Legal protection tests: Firm level}

This table reports estimates of different variants of the following Logit model for the likelihood of an ADR $i$ in country $m$ to experience an efficiency $\left(Y_{i}^{m}=E_{i}^{m}=1\right.$ in Panel A) or pricing $\left(Y_{i}^{m}=P_{i}^{m}=1\right.$ in Panel B) break over the sample (Eq. (11)):

$$
\operatorname{Pr}\left(Y_{i}^{m}=1\right)=\frac{e^{\alpha+\beta C G_{i}^{m}}}{1+e^{\alpha+\beta C G_{i}^{m}}}
$$

where $C G_{i}^{m}$ is the ratio between CLSA's corporate governance (CG) index for firm $i$ in country $m$ and country $m$ 's mean index. Column (1) reports the maximum likelihood estimates of $\beta$ and its corresponding $t$-statistic (in parentheses); column (2) reports estimates of $\beta$ when using the number of ADRs in the sample for which $C G_{i}^{m}$ was available in each country $m\left(n_{i}^{m}\right)$ as a weighting variable; column (3) reports estimates of $\beta$ when allowing for heteroskedasticity of the form $\operatorname{var}(\varepsilon)=\left(G C_{i}^{m}\right)^{\gamma}$; column (4) reports estimates of $\beta$ when allowing for fixed country effects $\left(\alpha^{m}+\beta C G_{i}^{m}\right)$; column (5) reports estimates of $\beta$ when allowing for random country effects $\left(\operatorname{Pr}\left(Y_{i}^{m}=1 \mid u^{m}\right)=\frac{1}{1+e^{-\left(\alpha+\beta C G_{i}^{m}\right)+u^{m}}}\right.$ and $\left.u^{m} \sim N\left(0, \sigma^{2}\right)\right) . n^{m}$ is the number of firms used for the corresponding estimation, after availability of the CG measure and corresponding data conditions are satisfied. The goodness-of-fit statistic $\chi^{2}$ tests the hypothesis that all estimated coefficients in Eq. (11) are zero. The $p$-values for this test (rounded to 4 decimals) are in parentheses. A "**, "** ", or "*** " indicate significance at the $10 \%, 5 \%$, or $1 \%$ level, respectively.

\begin{tabular}{|c|c|c|c|c|c|}
\hline \multirow[b]{3}{*}{ Coefficients } & \multicolumn{5}{|c|}{ Legal protection \& firm-level breaks } \\
\hline & \multicolumn{5}{|c|}{ Panel A: Efficiency breaks } \\
\hline & (1) & $(2)$ & $(3)$ & $(4)$ & $(5)$ \\
\hline$\beta$ & $\begin{array}{c}0.7803 \\
(0.61)\end{array}$ & $\begin{array}{c}0.9797 \\
(0.68)\end{array}$ & $\begin{array}{c}0.4977 \\
(0.12)\end{array}$ & $\begin{array}{c}0.4135 \\
(0.24)\end{array}$ & $\begin{array}{c}0.4599 \\
(0.45)\end{array}$ \\
\hline$n^{m}$ & 74 & 74 & 74 & 55 & 74 \\
\hline \multirow[t]{2}{*}{$\chi^{2}$} & $\begin{array}{c}0.3718 \\
(0.5420)\end{array}$ & $\begin{array}{c}0.4597 \\
(0.4978)\end{array}$ & $\begin{array}{c}0.6209 \\
(0.4307)\end{array}$ & n.a. & n.a. \\
\hline & \multicolumn{5}{|c|}{ Panel B: Pricing breaks } \\
\hline Coefficients & $(1)$ & $(2)$ & $(3)$ & $(4)$ & $(5)$ \\
\hline$\beta$ & $\begin{array}{c}0.2322 \\
(0.18)\end{array}$ & $\begin{array}{c}-0.8294 \\
(-0.54)\end{array}$ & $\begin{array}{c}-0.2613 \\
(-0.01)\end{array}$ & $\begin{array}{c}-0.2200 \\
(-0.13)\end{array}$ & $\begin{array}{c}0.1342 \\
(0.11)\end{array}$ \\
\hline$n^{m}$ & 74 & 74 & 74 & 60 & 74 \\
\hline$\chi^{2}$ & $\begin{array}{c}0.0318 \\
(0.8586)\end{array}$ & $\begin{array}{c}0.3014 \\
(0.5830)\end{array}$ & $\begin{array}{c}0.0514 \\
(0.8207)\end{array}$ & n.a. & n.a. \\
\hline
\end{tabular}




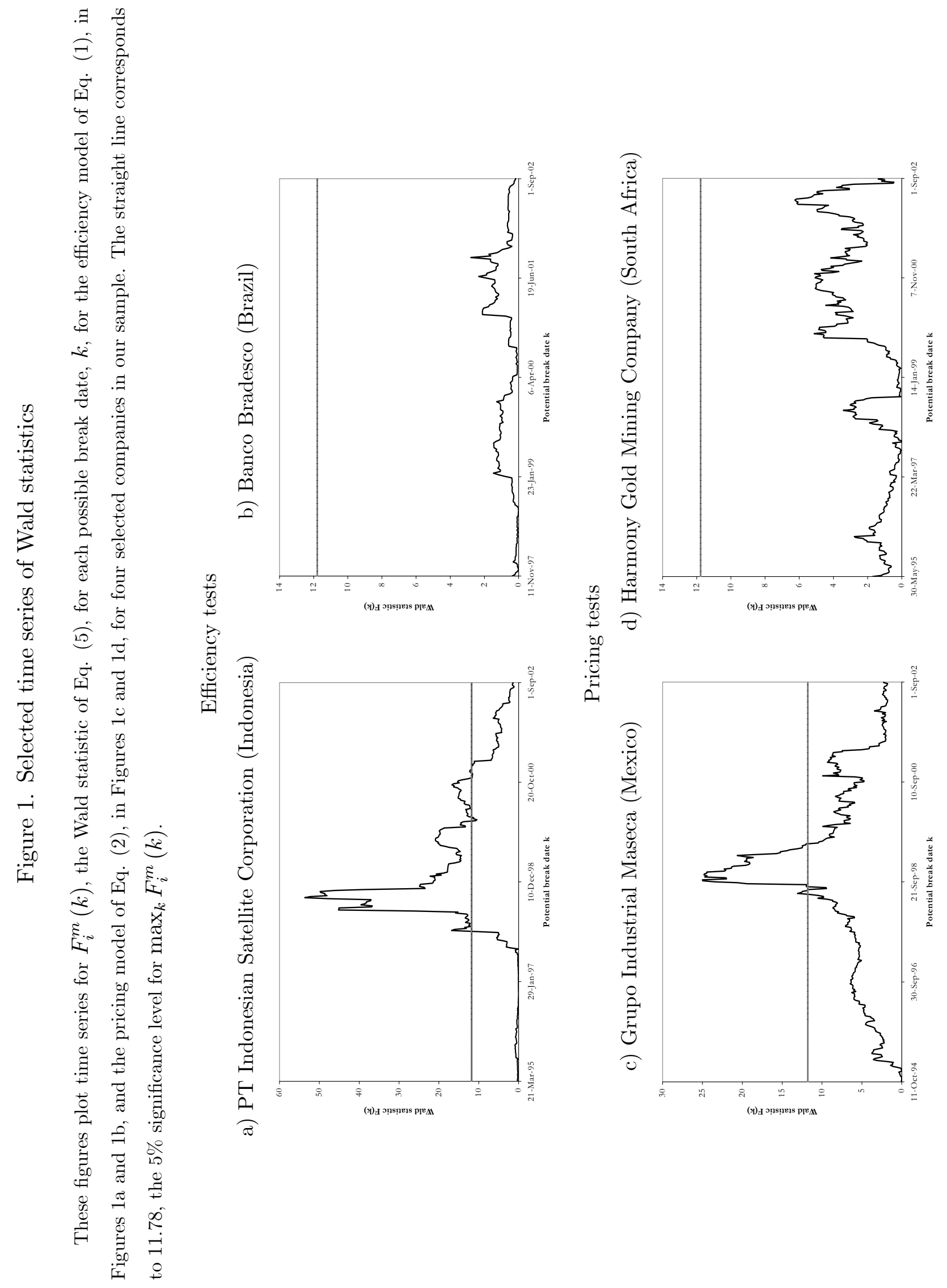


Figure 2. Scatter plots of regime shifts

These figures are scatter plots of the maximum of $F_{i}^{m}(k)$, the Wald statistic of Eq. (5), versus the corresponding estimated break date, $\widehat{k}_{i}^{m}$, for the efficiency model of Eq. (1), in Figure 1a, and the pricing model of Eq. (2), in Figure 1b, for each of the 156 ADRs in our sample. The straight line corresponds to 11.78, the 5\% significance level for $\max _{k} F_{i}^{m}(k)$. The figures also display the corresponding country label for those ADRs experiencing statistically significant breaks.

a) Efficiency tests

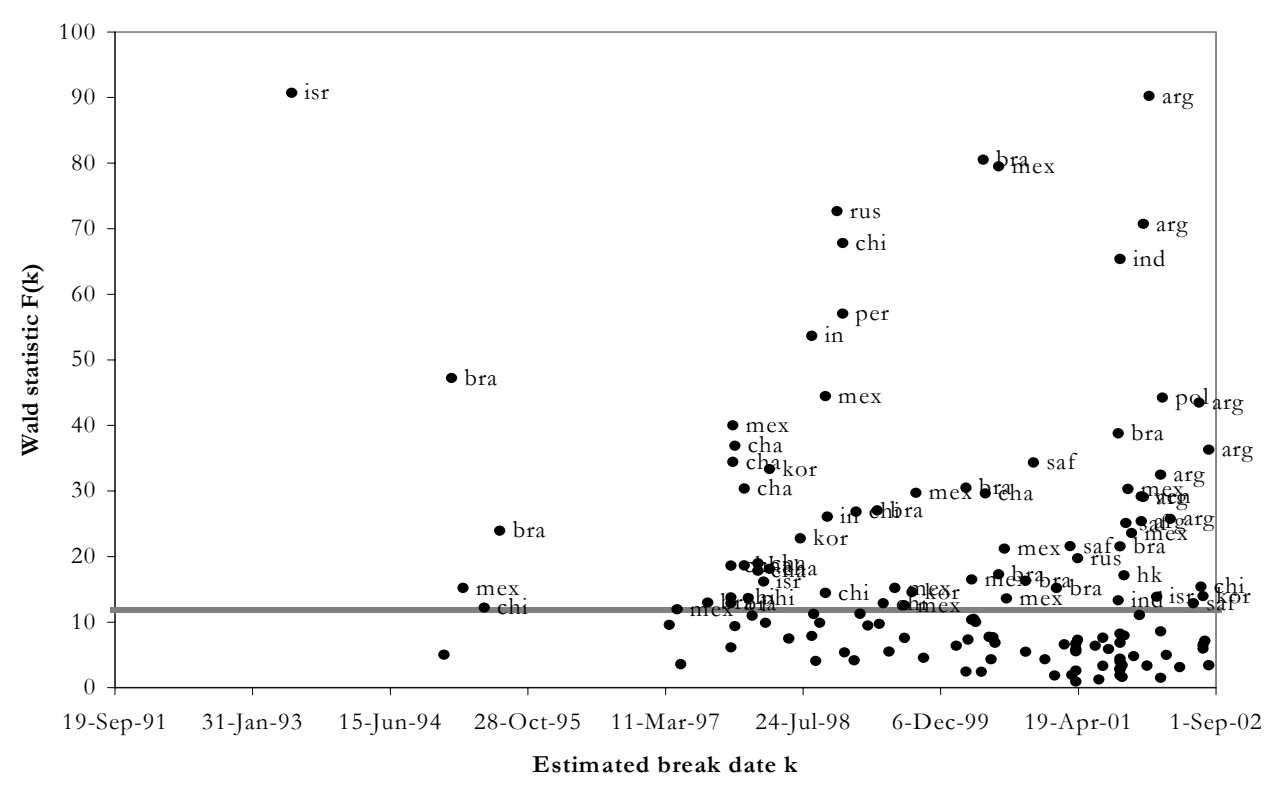

b) Pricing tests

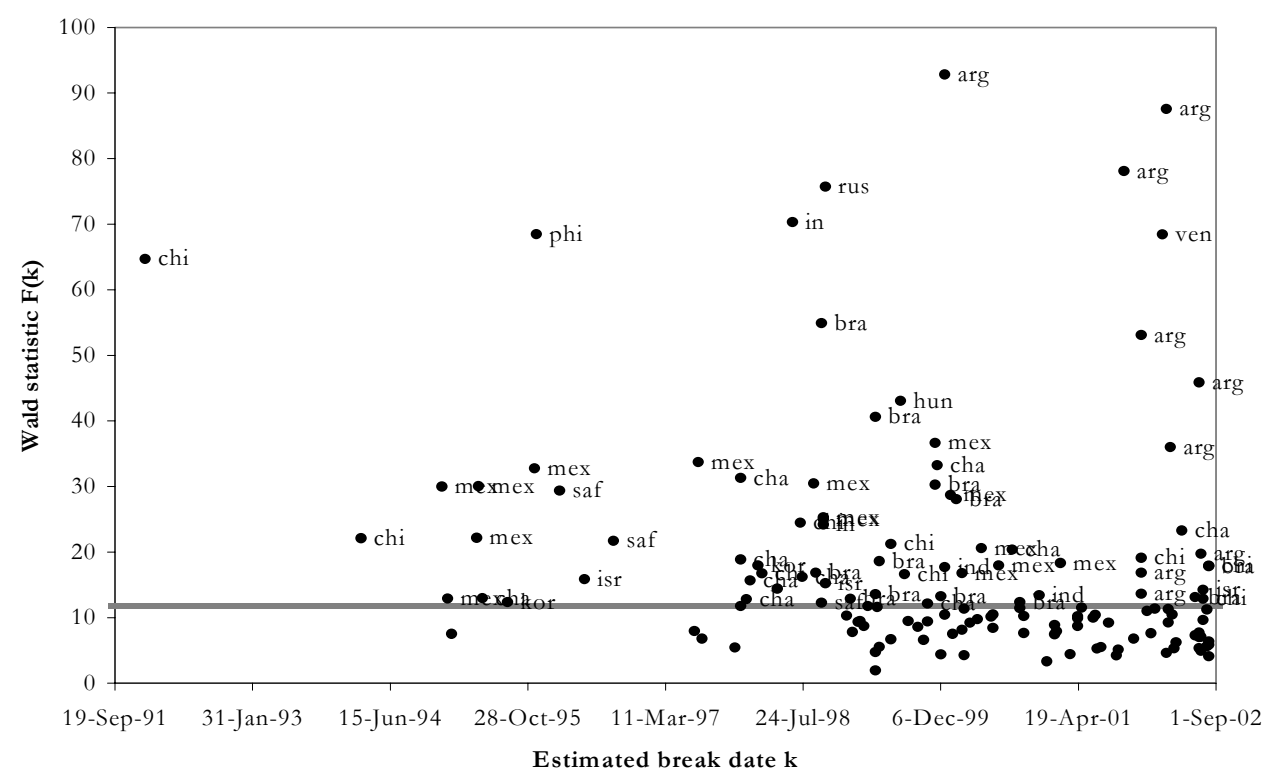




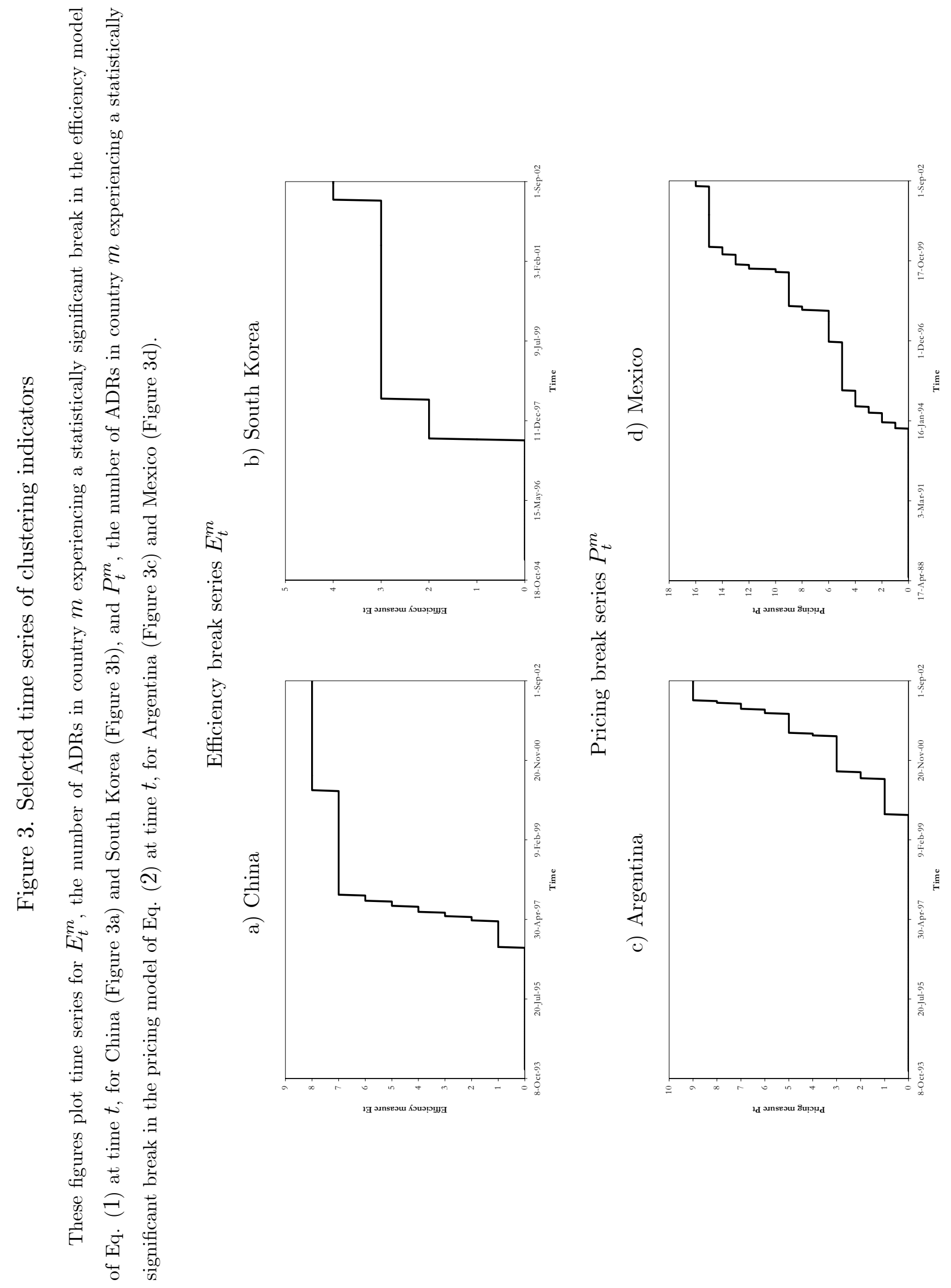

